\title{
RUDOLF SCHLECHTER'S SOUTH-AMERICAN ORCHIDS I. HISTORICAL AND BIBLIOGRAPHICAL BACKGROUND
}

\author{
Carlos Ossenbach ${ }^{1,2,4} \&$ Rudolf JenNy ${ }^{3}$ \\ ${ }^{1}$ Orquideario 25 de mayo, Sabanilla de Montes de Oca, San José, Costa Rica \\ ${ }^{2}$ Jardín Botánico Lankester, Universidad de Costa Rica, Costa Rica \\ ${ }^{3}$ Jany Renz Herbarium, Swiss Orchid Foundation, Switzerland \\ ${ }^{4}$ Corresponding author: caossenb@racsa.co.cr
}

\begin{abstract}
This study represents the first part of a series dedicated to the work of Rudolf Schlechter on the orchid flora of South America. The historical background of Schlechter's botanical activity is outlined, and salient aspects of his biography, as well as his main scientific relationships, in particular with Oakes Ames, and the origins of his interest in tropical America are discussed. We also present a complete bibliography relative to Schlechter's production on the orchid floras of South American countries, with his network of orchid collectors, growers and other purveyors, and checklists of all the new taxa that he described from each individual country.
\end{abstract}

KEY wORDS: bibliography, biography, history of botany, Orchidaceae, South America

Historical background ${ }^{1}$. One will hardly find any scholar who was such an ardent and unconditional defender of Rudolf Schlechter as the late Karlheinz Senghas (1928-2004), who made the study of Schlechter's work one of the goals of his life. Senghas (2002: 1) answers the question about the most important German orchidologists by using the term "the three Popes" when referring to Heinrich Gustav Reichenbach, or Reichenbach filius (1824-1899), from Hamburg (Fig. 1A), Ernst Hugo Heinrich Pfitzer (18461906) from Heidelberg (Fig. 1B) and Friedrich Richard Rudolf Schlechter (1872-1925), from Berlin (Fig. 2).

Of these three, Rudolf Schlechter must be credited with having described the largest number of new orchid genera and species, monographic revisions of genera and subtribes, and national and regional orchid floras. The publication of Die Orchideen (1915) was, years before the end of his scientific work, the crowning moment of his career (Senghas, 2002: 1).

A man of egoistic self-confidence and driving ambition, Schlechter had an enormous capacity for work and a remarkable memory; it is said that at an early age he had set for himself the goal of describing at least one new orchid every day and indeed he proposed in excess of 5,000.

Schlechter was born on October 16, 1872 in Berlin, the third of six children. His father, Hugo Schlechter, was a lithographer. After finishing school at the Friedrich Wilhelm Gymnasium, he started education in horticulture, first at the market garden of Mrs. Bluth and then at the botanical garden of the University of Berlin. There he worked as an assistant until the autumn of 1891 , when he left Europe on his first botanical expedition to southern Africa. He was only 19 years of age.

After arriving in Cape Town he worked as a gardener and as an inspector of grape vines for phylloxera. He then was employed as an assistant in the private herbarium of Dr. Harry Bolus, where he must have learned quite a bit about the local flora from his employer ${ }^{2}$. Bolus' herbarium was later acquired by Cape Town University. From 1891-1892 Schlechter collected plants in the surroundings of the city. After leaving Bolus in 1892, he explored other regions in the southern and eastern Cape, Transkei, Natal and Transvaal until 1895, when he returned to Europe and published his first paper on the plant family to which he would devote the rest of his life, the orchids ${ }^{3}$.

Schlechter returned to Europe with copious collections of both asclepiads and orchids, on which

\footnotetext{
1 Many important facts about Schlechter's life are based on information in the National History Museum, 2013, as well as on K. Senghas (2002: 1-10).

2 Bolus, together with John M. Wood, Peter Macowan, and Rudolf Marloth, were known as the "Big Four of SouthAfrican Botany".

3 Schlechter, R. 1895. Beiträge zur Kenntnis neuer und kritischer Orchideen aus Südafrika (Contributions to the knowledge of new and critical orchids from South.Africa). Bot. Jahrb. Syst. 20, Beibl. 50: 1-44.
} 

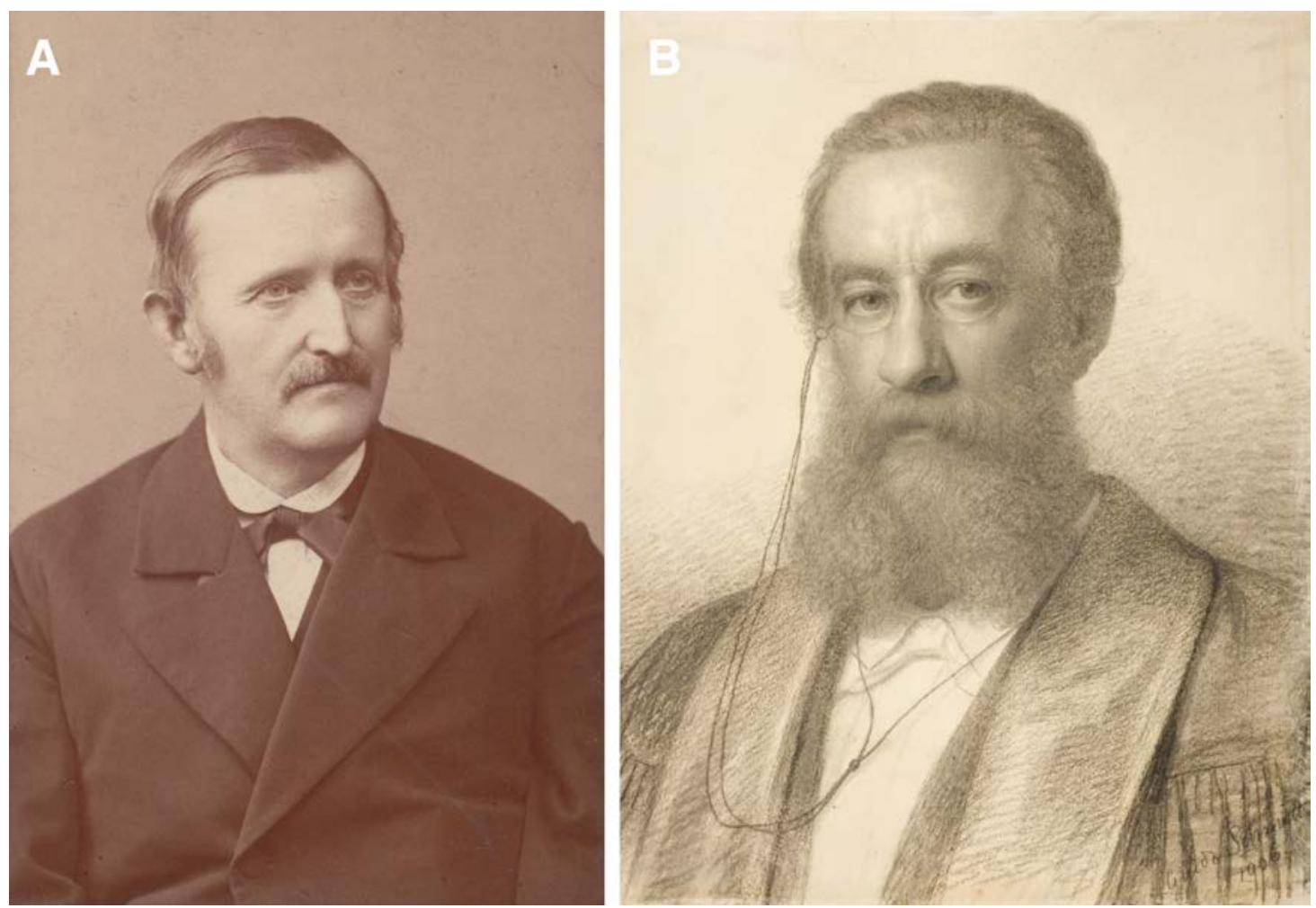

FiguRE 1. A - Heinrich Gustav Reichenbach (1824-1899). Courtesy of the Archives, Naturhistorisches Museums, Wien.

B - Ernst Hugo Heinrich Pfitzer (1846-1906). Charcoal by Guido Philipp Schmidt.

he worked at the Botany Department of the British Museum in London. There he established a relationship with Alfred B. Rendle (1865-1938) (Fig. 3A). Together they later researched on the Asclepidaceae of tropical Africa ${ }^{4}$.

In 1896 Schlechter returned to southern Africa and was joined by his brother Max, with whom he travelled north to the Vanrhynsdorp district, returning to Cape Town that September. Between November 1896 and April 1897, they collected northwards to the Cedarberg and eastwards to Cape Agulhas. In August 1897 the two brothers set out for Namaqualand and reached the Orange River at Ramansdrift. Schlechter was then in Mozambique from late 1897 to early 1898. Dr. S. Schonland, director of the Albany Museum in Grahamstown (Eastern Cape Province), who received plants from Schlechter, described him as the most acute and most successful botanical collector who ever visited

4 Schlechter, R. \& Rendle, A.B. 1896. New African Asclepiads. Journal of Botany, British and Foreign 34: 97-100.
South Africa (Schonland, 1897: 5). Schlechter returned to the University of Berlin in April 1898, drained and weakened by dysentery and tropical fevers. This was nevertheles an important period for the young botanist, for he was able to work with such renowned colleagues as Heinrich Gustav Adolf Engler (1844-1930) (who was his tutor while writing his Ph.D. thesis) (Fig. 3B-4), Friedrich Ludwig Emil Diels (1874-1945) (Fig. 4) and Otto Warburg (1859-1938) (Fig. 5A). It was the latter, an economic botanist, who probably saw that Schlechter was hired by the German Colonial Department to lead an expedition to West Africa in search of latex-producing plants (the Westafrikanische Kautschuk-Expedition, 1899-1900) (Fig. 5B).

Over the next decades Schlechter was continuously involved in expeditions, visiting Sumatra, Java, Celebes, Borneo, New Guinea and Australia. In 1901-1903, again under contract with the Colonial Department, he explored Malaysia, Indonesia, German New Guinea and the South Sea islands. He proceeded to Sydney and then New Caledonia in 1902, 


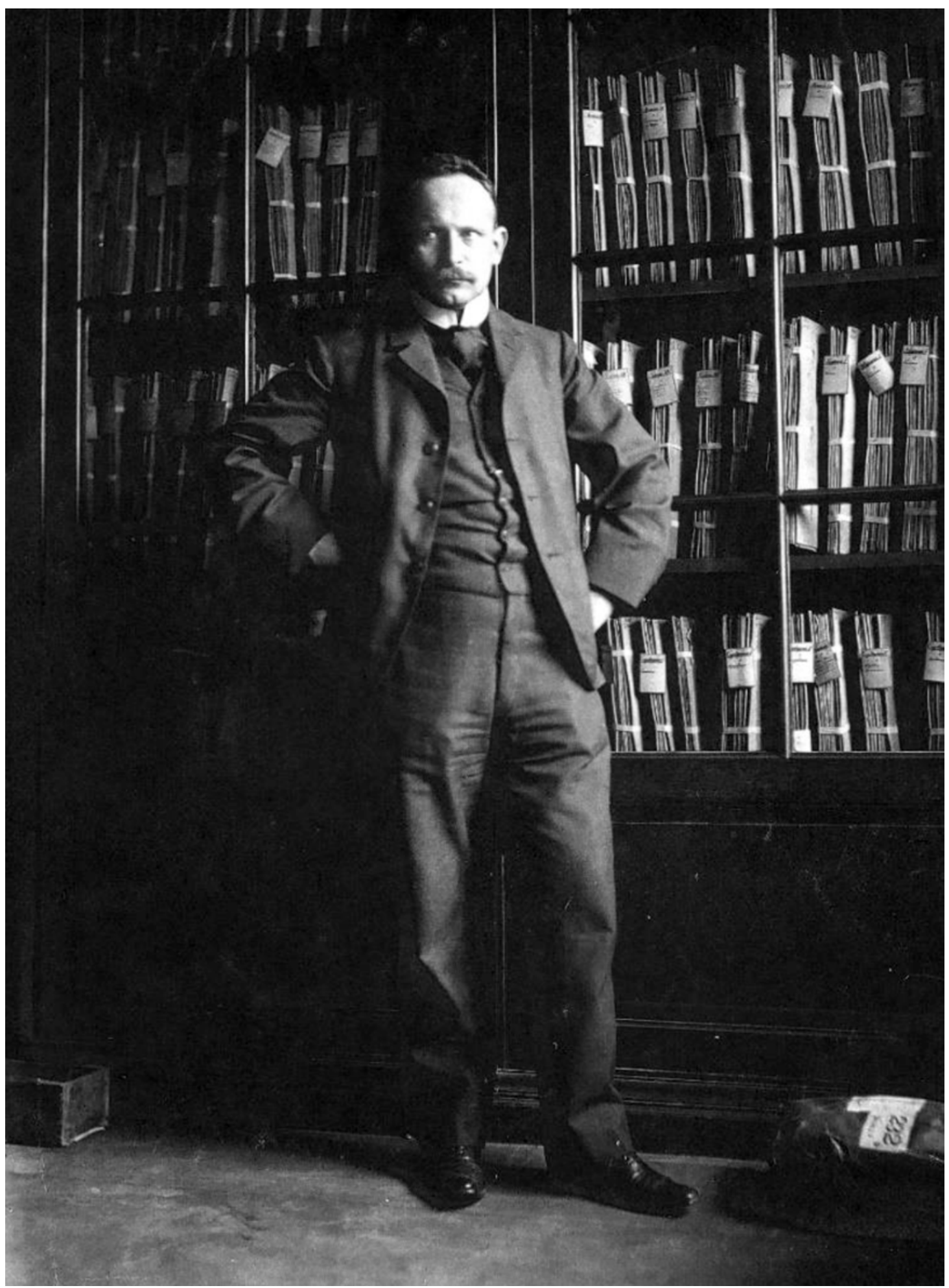

FIGURE 2. Friedrich Wilhelm Rudolf Schlechter (1872-1925). Archives of Rudolf Jenny. 

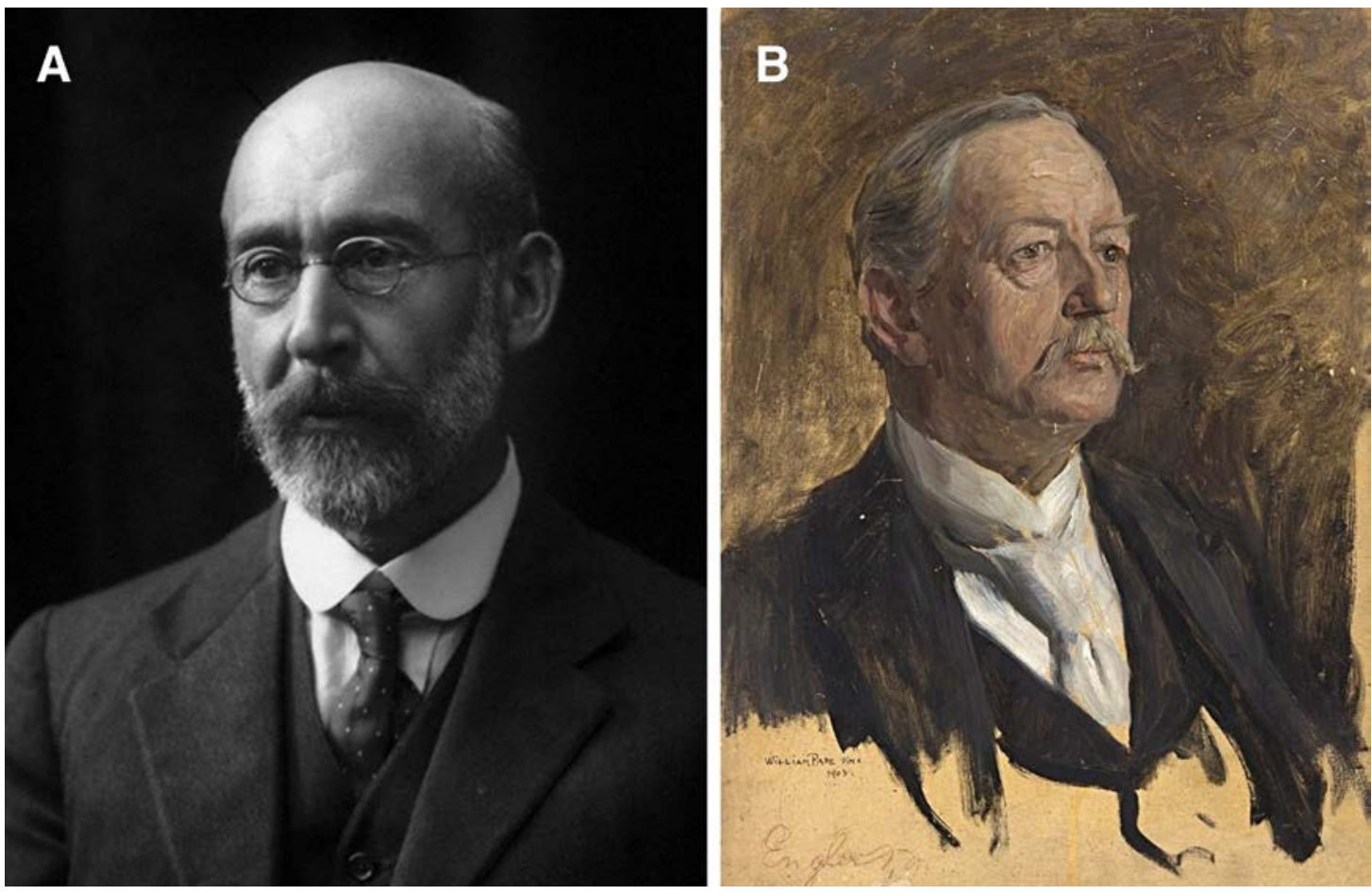

Figure 3. A - Alfred Barton Rendle (1865-1938). Photograph by Walter Stoneman. B - Friedrich Gustav Adolf Engler (1844-1930). Study of a portrait by William Page.

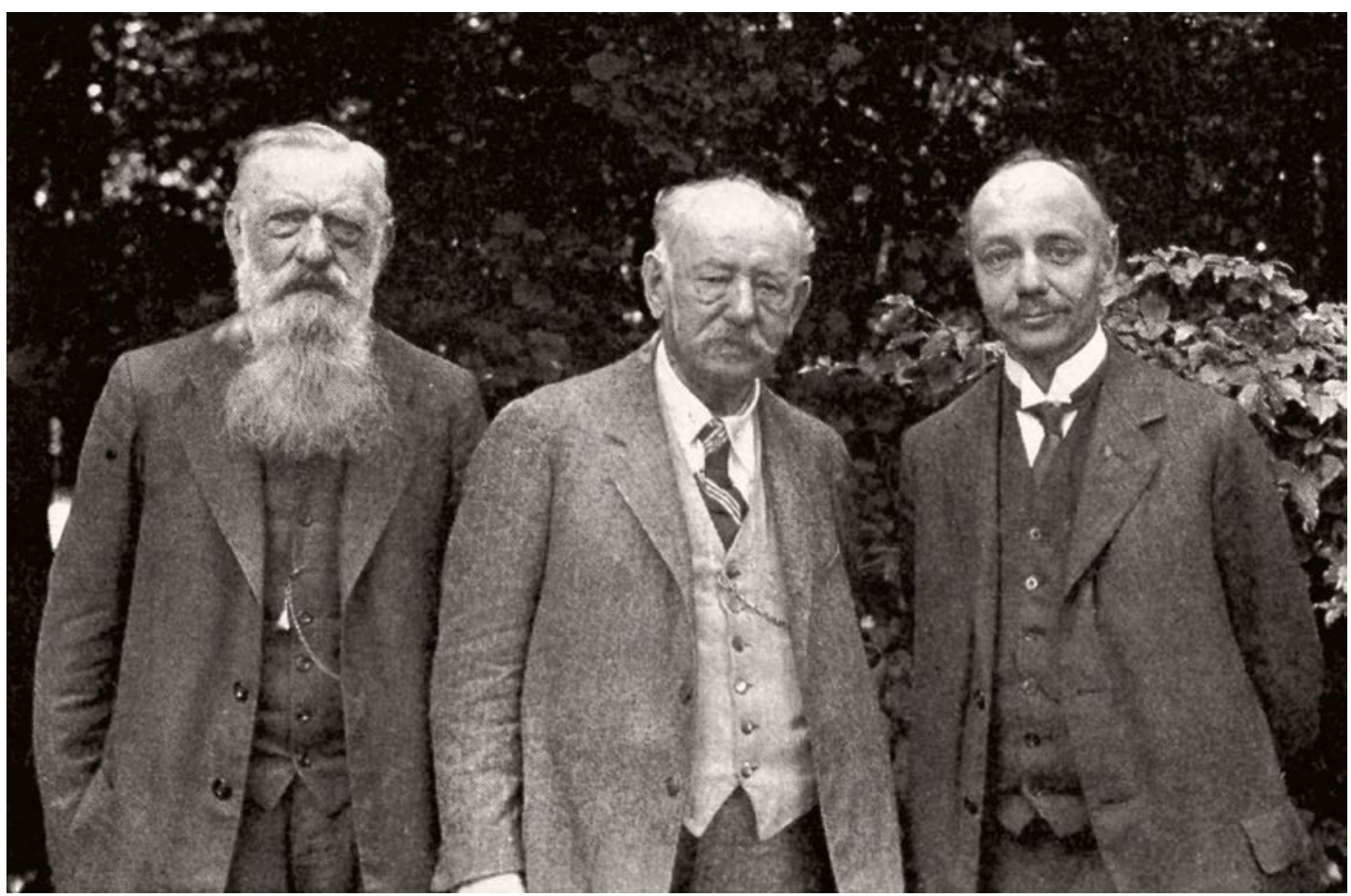

FiguRE 4. Left to right: Ignaz Urban (1858-1931), Adolf Engler, Ludwig Diels (1874-1945). Archives of Rudolf Jenny. 

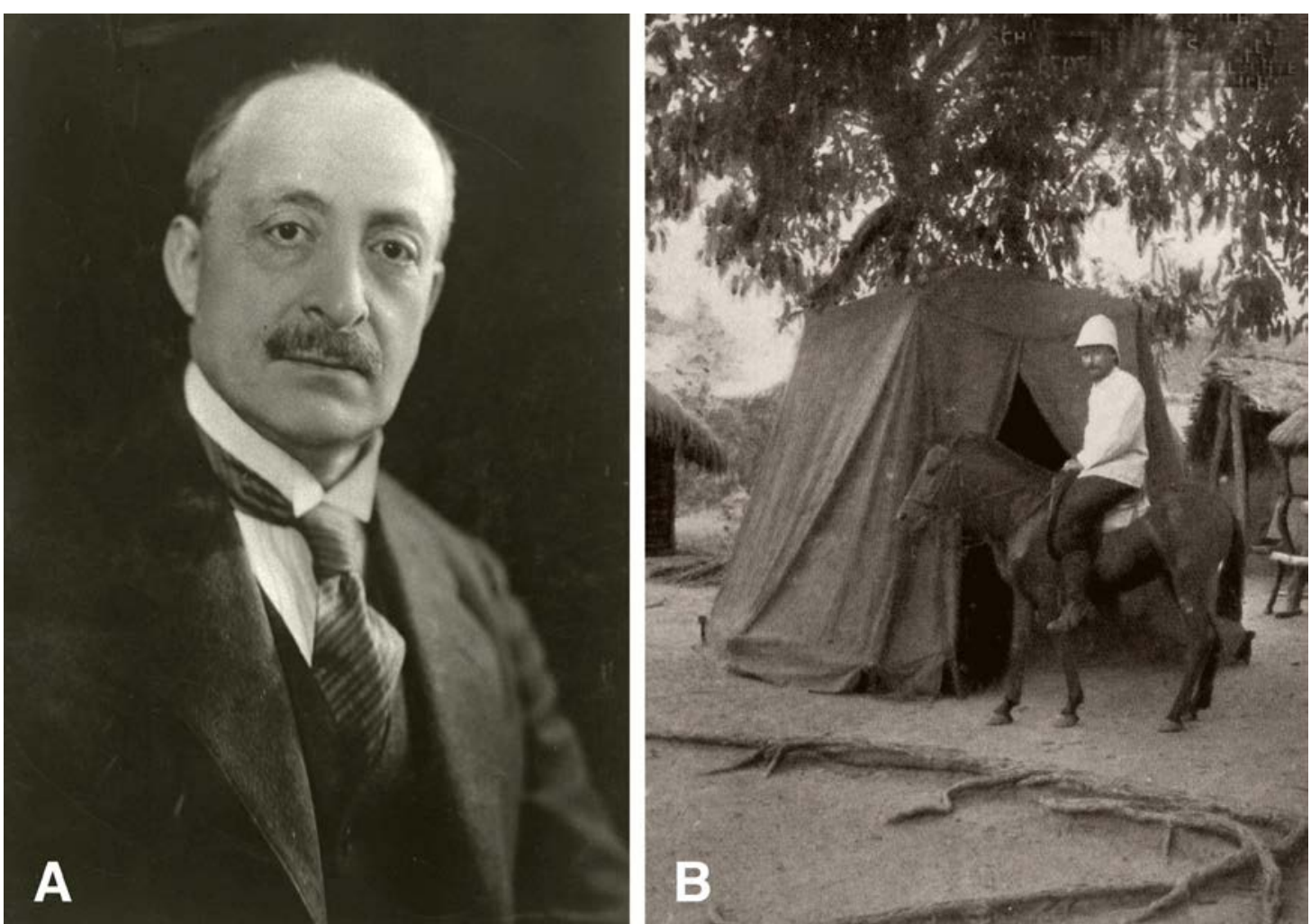

Figure 5. A - Otto Warburg (1859-1938). Archives of Rudolf Jenny. B - Rudolf Schlechter in front of his tent in Kadyebi (Togo), 1900. In Fibeck, 2012, part II: 169. 1.

sailing back to Germany in 1903. After completing his doctoral thesis on the phytogeography of New Caledonia, he made another brief trip to West Africa to assess progress with the cultivation of Silkrubber (Funtumia elastica Stapf).

In 1906 he embarked on his longest and last expedition, this time back to the Malay archipelago, visiting Hong Kong, the Philippines, Sumatra, Borneo and New Guinea (which served as his base). Although he had been commissioned to establish a rubber research station at the Papuan village of Bulu, it is his botanical collections during this time for which he is best remembered. In 1910 he was back in Berlin, where he began his major work, Die Orchidaceen von Deutsch-Neu-Guinea. Published between 1911 and 1914, its 14 volumes numbered over 1,000 pages, in which he described about 1,500 new orchid species.

Schlechter's work had been preceded, after the death of Reichenbach, by Ernst Hugo Heinrich Pfitzer. Pfitzer, who since 1872 was professor and director of the Botanical Garden of Königsberg (Prussia), and dedicated himself to the classification of the Orchidaceae and published his Beiträge zur Systematik der Orchideen (Contributions to the Systematics of Orchids) in 1895.

Another contemporary of Schlechter was Friedrich Wilhelm Ludwig Kraenzlin (1847-1934) (Fig. 6). studied chemistry and botany at Berlin and Königsberg, receiving his Ph.D. in 1867. He later worked as an assistant to Wilhelm Hofmeister in Heidelberg and under Johannes von Hanstein at the University of Bonn. From 1872 to 1906 he was a professor and director of the botanical garden at Heidelberg. In the first edition of Die Natürlichen Pflanzenfamilien ${ }^{5}$ (The natural families of plants), a work by Adolf Engler and Carl Prantl, Kraenzlin collaborated on the treatment on orchids.

Kraenzlin's work was, however, severely criticized by many of his colleagues. Rudolf Schlechter was no exception. Writing to Oakes Ames on September 12, 1910, he gave his opinion

\footnotetext{
5 Engler, A. \& Prantl, K. 1897-1915. Die natürlichen Pflanzenfamilien. Engelmann, Leipzig.
} 


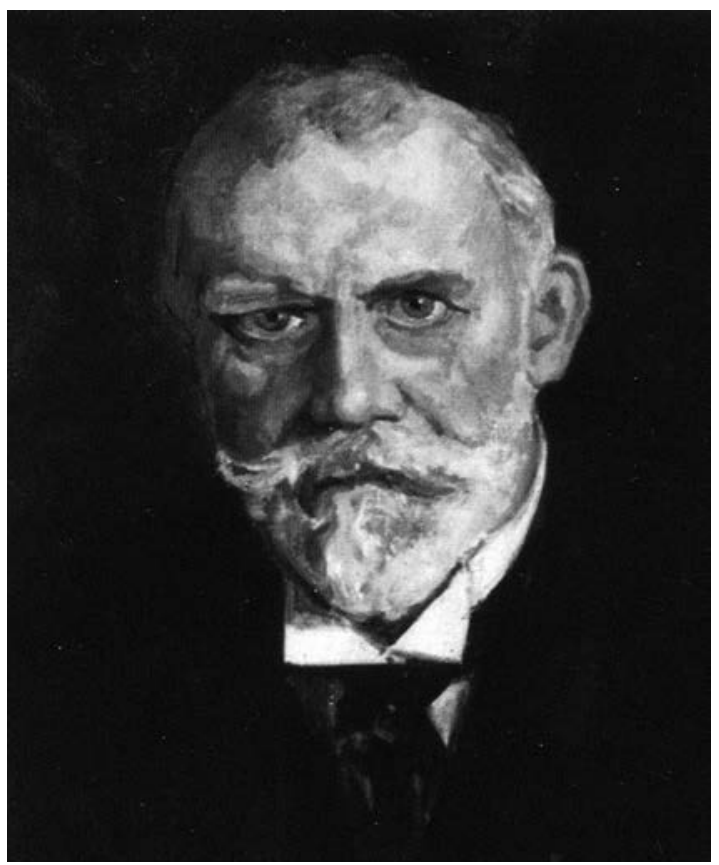

FIGURE 6. Friedrich Wilhelm Ludwig Kraenzlin (18471934). Archives of Rudolf Jenny.

on Kraenzlin's monograph of Dendrobium: "I am very curious to see what Kränzlin's monograph of Dendrobium will be like; from what I see in the Berlin Herbarium in the way of his determinations there will quite a lot of ridiculousness in it and this work will be the crown of foolishness in a man who really has not given a single usuable work to science in spite of his long years of work. Sometimes it almost appears to me as if he is not actually determinating his plants, but raffling them out." And Ames was equally critical. On December 4, 1910 he replied to Schlechter on the same subject: "I have just received Dr. Kränzlin's monograph of Dendrobium. I have not yet put it to the test, but in several places I have detected errors which are unpardonable and in every way avoidable."

Between collecting trips Schlechter continued his visits to London, always stopping in at the herbarium at Kew and the British Museum. He was considered an interesting figure, but being not respectful of persons or things, he was apt to tread on other people's feelings and sensibilities. He was dogmatic in his convictions, a characteristic which did not assist in making him popular; but on the basis of his achievements and experience, he was accorded great respect (Reinikka,
1995: 294). Frequent visits were also made to the herbaria in Paris, Leiden, Brussels, and Vienna.

Shortly after his last expedition, Schlechter married Alexandra Sobennikoff, the daughter of a Russian merchant, with whom he raised two daughters. In 1925 he dedicated the Malagasy orchid genus Sobennikoffia to his wife.

Rudolf Schlechter became Secretary of the Orchid Committee of the German Horticultural Society in 1914, and in 1915 editor of the journal Orchis. In the same year he finished the publication of the last fascicle of the first edition of his Die Orchideen ${ }^{6}$, the work that has made him famous to the present day. The First World War interrupted Schlechter's botanical career as he served as officer in the German Army during 1916 and 1917 (Fig. 7). After WWI and until his death in 1925 Schlechter focused on expanding his research collection of orchids.

His production of publications from his orchid research reached its highest point during this period. From a total of 333 publications by Schlechter, 233 were dedicated to Orchidaceae, with the description of some 170 new genera and over 5,500 new orchid species. Among his publications were descriptions of new genera and species, multiple revisions of orchid genera and 20 works about national and regional orchid floras.

Schlechter spent the last 15 years of his career at the Berlin Botanical Museum, where he became a curator in 1921 . He died at the relatively young age of 53, in 1925, apparently from the lingering effects of tropical diseases he had contracted during his expeditions. It was, however, fortunate that he did not live to see the destruction of one of his greatest achievements: his collections were destroyed along with the Berlin herbarium by allied bombing on the night of March 1 , 1943 (Fig. 8).

Rudolf Schlechter's name lives on in the genera Schlechteranthus Schwantes (Aizoaceae), Schlechteria Bolus ex Schltr. (Brassicaceae), Schlechterella K.Schum (Asclepidaceae), Schlechterina Harms (Passifloraceae) and Rudolfiella Hoehne (Orchidaceae). Forty-one orchid species carry his name.

6 Schlechter, R. 1915. Die Orchideen: ihre Beschreibung, Kultur und Züchtung. Handbuch für Orchideenliebhaber, Züchter und Botaniker. Berlin, P. Parey. 


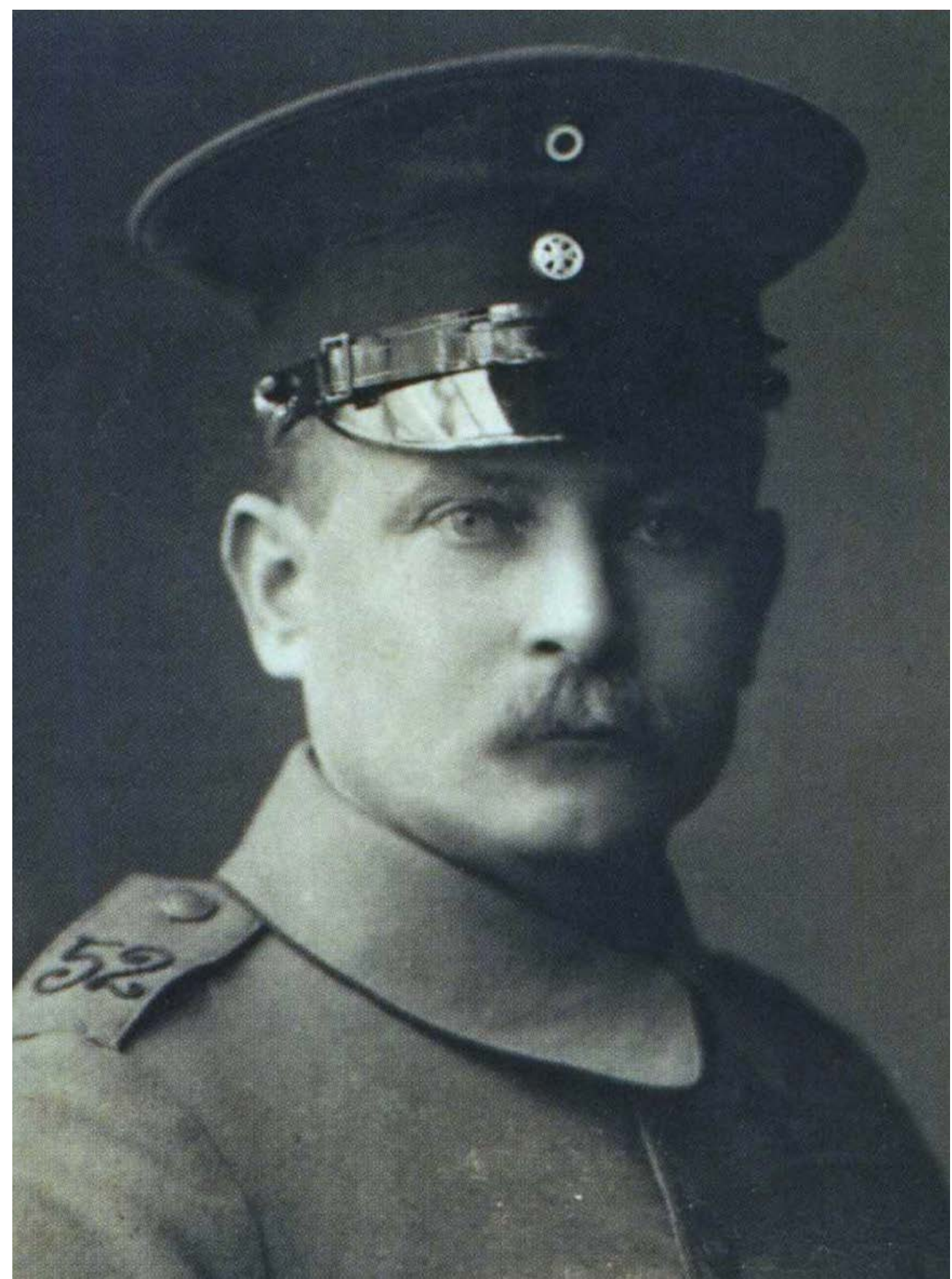

FiguRE 7. Rudolf Schlechter as infantry-officer, WWI. In Fibeck, 2014, part V: 59. 


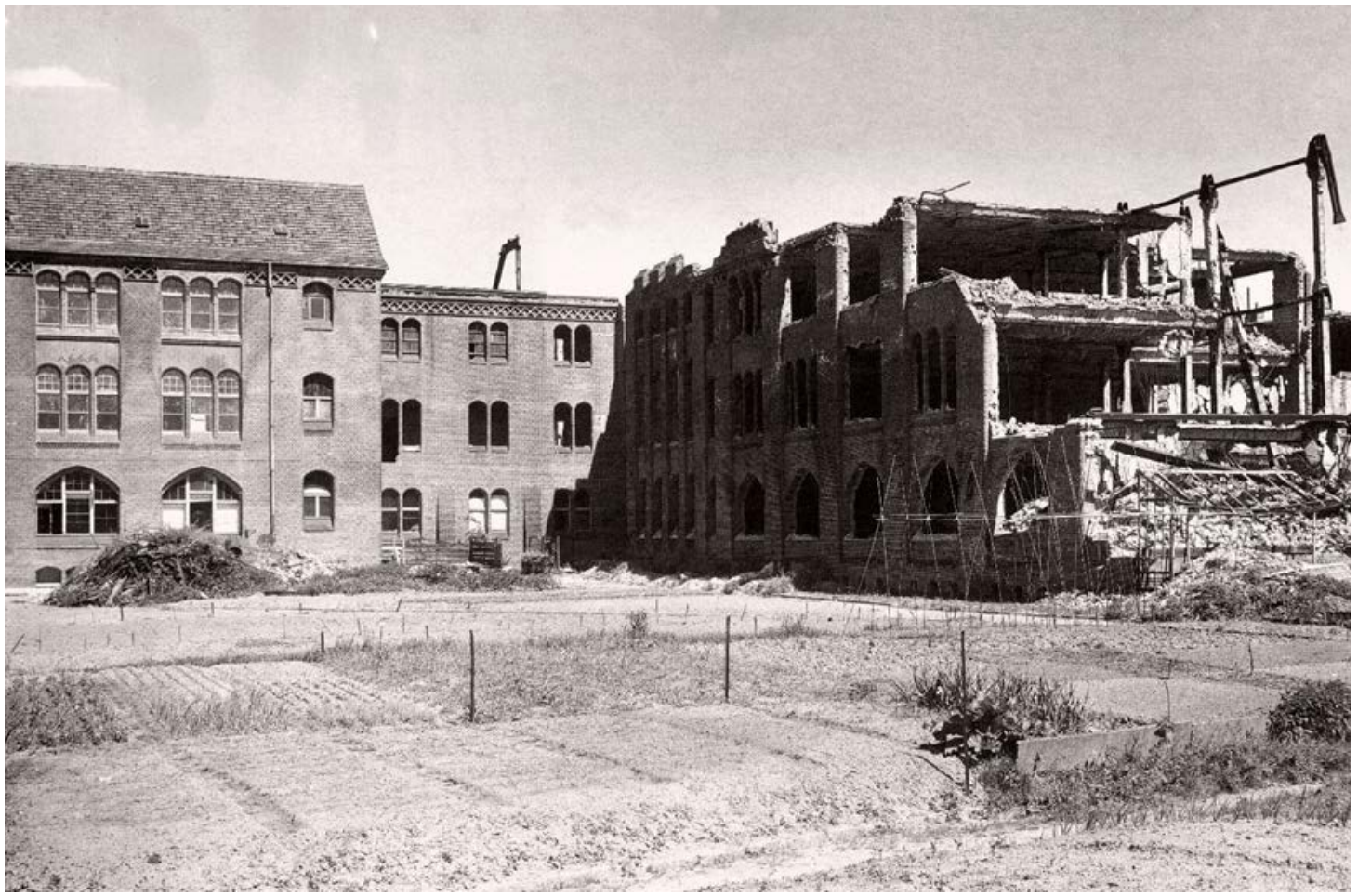

FIgURE 8. Berlin Herbarium destroyed during WWII, 1943. Archives of Rudolf Jenny.

Bibliographical background - Schlechter's interest in tropical America. Rudolf Schlechter's first contact with the orchids of South America's vast territory (Fig. 9) was undoubtedly his study of the large collections of orchids by Friedrich Carl Lehmann (1850-1903) held by the British Museum in London. Lehmann began to sell herbarium specimens to the British Museum in 1888, and Robert A. Rolfe was engaged in describing them at Kew. When Schlechter arrived in London in 1898 after his first SouthAfrican expedition, the British Museum already had a significant number of Lehmann's Colombian orchid specimens, although Lehmann's early collections were buried in Vienna, together with the rest of Reichenbach's Herbarium. Rudolf Schlechter, in his works of 1920 and 1924 on the Colombian orchid flora, made frequent reference to specimens collected by Lehmann.

Schlechter's publications on orchids that refer to South American orchids can be roughly divided into four periods: the years before WWI, especially those after his return from Papua \& New Guinea in 1909 (21 publications); the war years (1914-1918,
30 publications); the postwar years, from 1919 to his death in 1925 (44 publications). There were, additionally, posthumous publications of his works by his wife, Alexandra, Rudolf Mansfeld and others (17 publications).

Schlechter's first publication on tropical orchids from the New World was a product of the return to Germany of Robert Knud Friedrich Pilger(1876-1953), who had travelled as a botanist with an expedition to the Matto Grosso, Brazil, led by Dr. Hermann Meyer (1871-1932), in the years 1899 and 1900. Pilger worked at the Botanical Museum in Berlin on the plants collected during his journey, contacting leading specialists in the different plant families to assist him in the determinations. Schlechter was chosen to work on his favorite family, the Orchidaceae, in Pilger's Beitrag zur Flora von Mattogrosso (Pilger, 1901: 149-150) describing the relatively small number of 7 orchid species, of which only one (Habenaria pilgeri) was new to science.

We find the next two publications by Schlechter, describing a few new orchid species from Brazil and Colombia, five years later, in 1906 . We then have to 


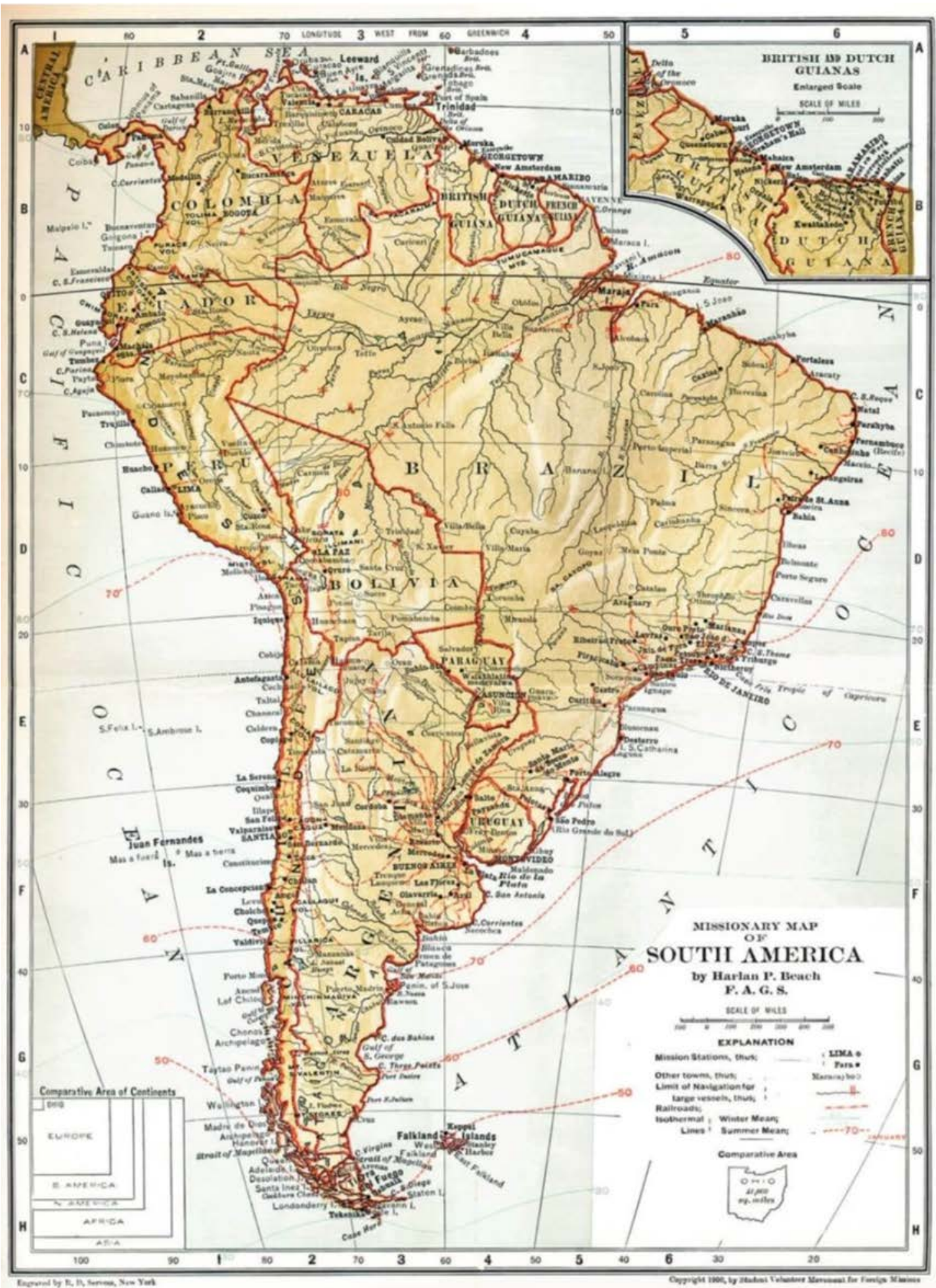

Figure 9. Map of South America by Harlan P. Beach, ca. 1900. 


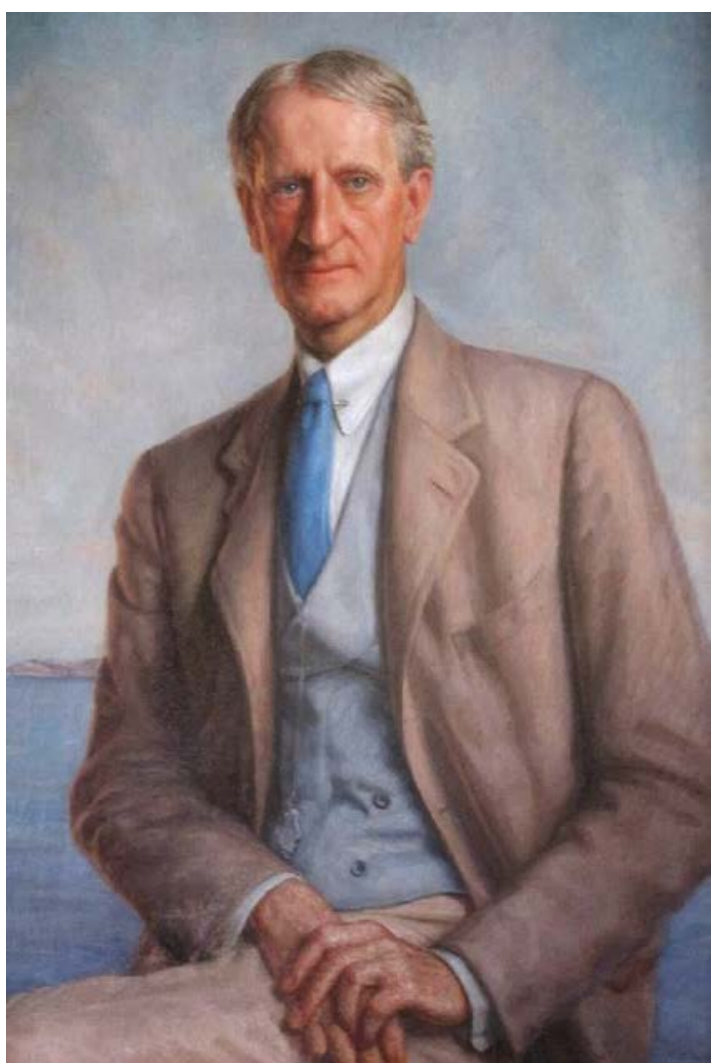

Figure 10. Oakes Ames (1874-1950). Portrait by his wife,

Blanche Ames.

wait until 1910 to hear from him again. This unusually unproductive period has naturally to be ascribed to Schlechter's long expeditions to Africa, South-East Asia, Australia, and Papua \& New Guinea, which kept him away from Berlin during the best part of the first decade of the 20th century. There was a brief interlude from 1903 to 1906, the time he spent finishing his studies in Berlin and receiving his Ph.D.

Correspondence between individuals has always been one of the primary sources for those writing on history. In our case, we can count ourselves fortunate for being able to read and study the copious correspondence between Rudolf Schlechter and Oakes Ames (1874-1950) (Fig. 10) over a period of some fifteen years. This treasure is today well kept at the Oakes Ames Herbarium of Harvard University. It is not clear how Schlechter established the first contact with the great Harvard botanist, although it was presumably through common acquaintances at Kew. Ames, when writing about the destruction of the herbarium in
Berlin (1944) says that "nearly half a century ago my acquaintance with Schlechter began." This would have been coincidental with Schlechter's visit to Kew after his first African expedition, so it must have been sometime between 1898 and 1900 .

Over 350 pages of letters -mostly typed in the case of Ames; always in his untidy handwriting by Schlechter- give us an impressive insight into each man's particular circumstances and constitute a detailed timeline, especially with regard to Schlechter's publications and his personal, difficult circumstances. Although their relationship grew through the years to one of deep friendship -to a point where the biography of either botanist during this period can only be written with constant mention of the other- the differences in character, as well as in economic and social standing, could hardly be more extreme. Schlechter came from a middle-class family and had to work his way up through untiring personal effort; Ames was born into a family of millionaires, the elite of the high socierty of New England (Fig. 11). Ames' grandfather has been credited by many historians as being the single most important influence in the building of the Union Pacific portion of the transcontinental railroad. While Schlechter spent the first fifteen years of his mature life in extensive and exhausting expeditions through Africa, Southeast Asia, and Australia, developing a deep understanding of orchids in relation to their natural habitats, Ames hardly ever left the sumptuous comfort of his native Boston and his research on orchids was always based on herbarium specimens of plants which he had seldom seen growing in their natural habitats, or on the few living plants growing in the Harvard Botanic Garden.

Schlechter was an incredibly hard worker who produced an average of over 20 publications per year, including such major works as his Die Orchideen; Ames, in his own words, was an intermittent worker who wandered from the job, 'a slave of inclination' as he defined himself, for whom there were months at a stretch when he considereed botanical work 'a perfected form of torture'. His literary production -compared with that of Schlechter- was relatively meager. Schlechter was the most important orchidologist of his time, while Ames played a relatively smaller role. 

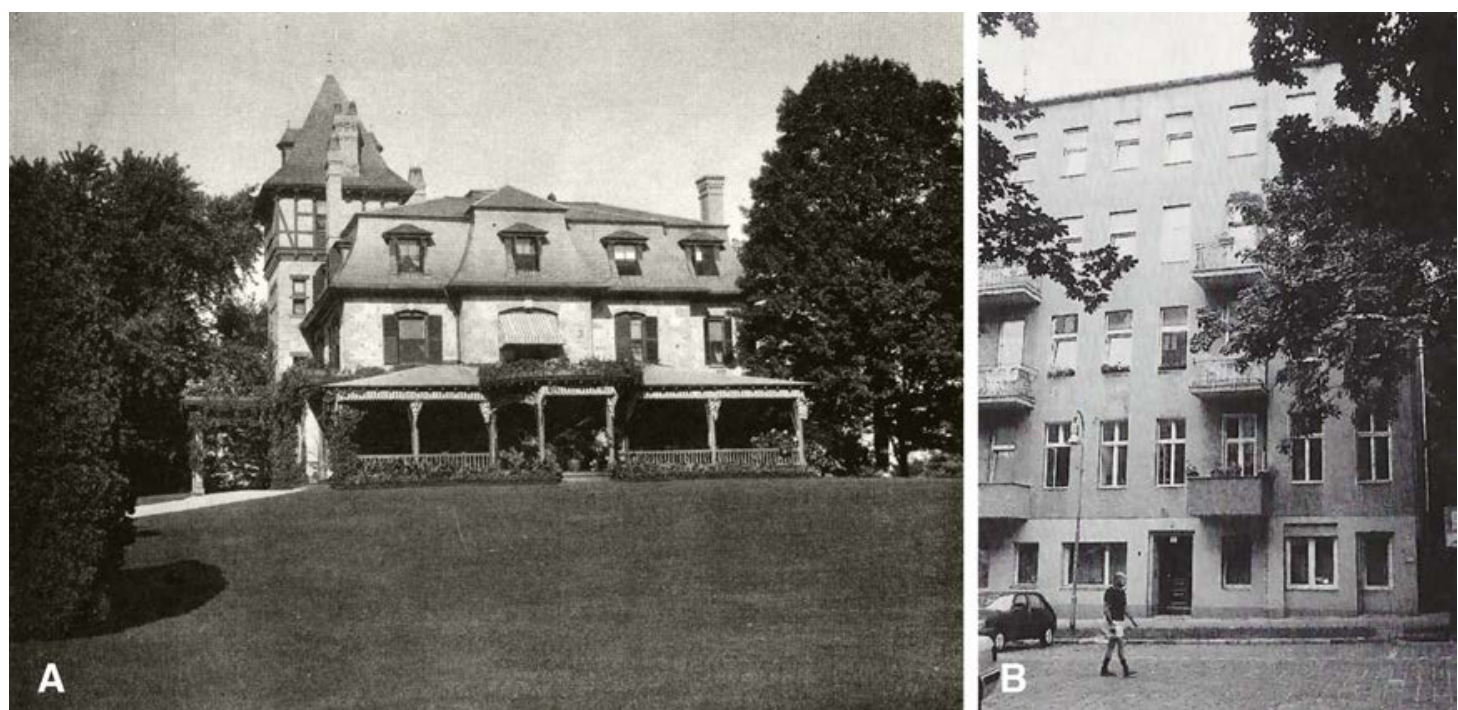

Figure 11. A - Homestead of the Ames family, were Oakes Ames was born and lived in the first years of his marriage (North Easton, Massachusetts). B - Building on Neue Culmstrasse N5a, where Schlechter lived around 1914 (BerlinSchöneberg). The building was heavily damaged during the war and rebuilt afterwards.

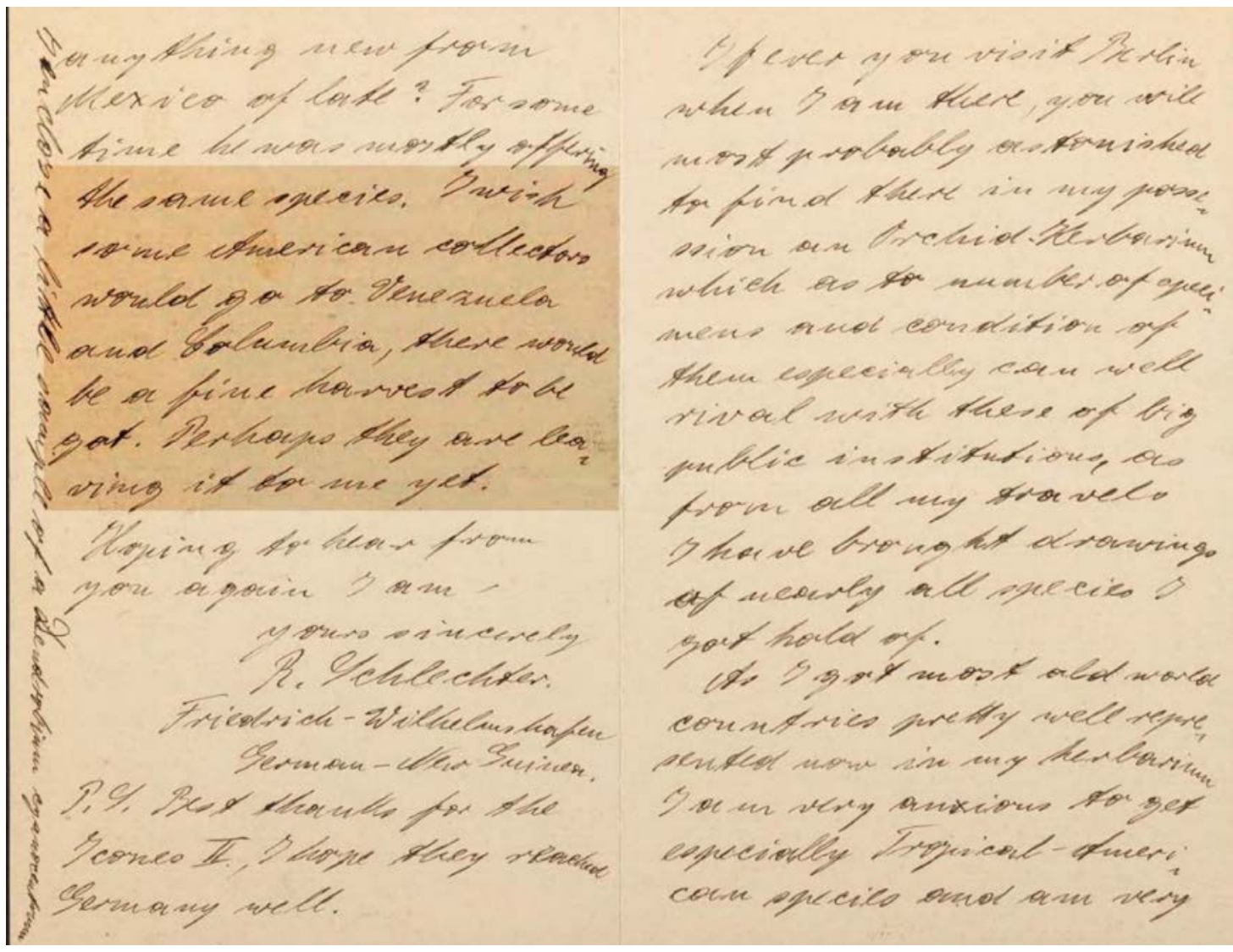

FIgURE 12. Letter from Schlechter to Ames, Feb. 2, 1909: "I wish some American collectors would go to Venezuela and Columbia, there would be a fine harvest to be got. [...]”. In Oakes Ames Orchid Herbarium, Harvard University. 


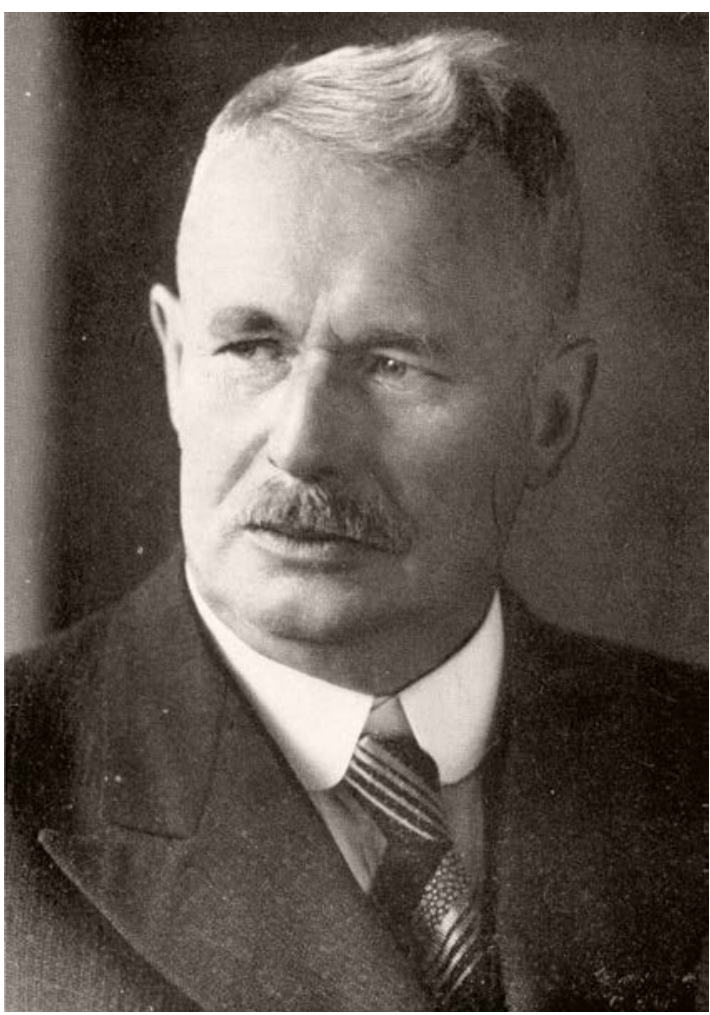

Figure 13. Friedrich Karl Gustav Fedde (1873-1942).

Archives of Rudolf Jenny.

However, Ames amassed an orchid herbarium which, before being integrated into the larger collection of Harvard University, contained about 131,000 plant specimens, around 3,000 flowers in glycerin, 4,000 specimens in liquid and hundreds of line drawings that supplemented the specimens. Part of this herbarium were hundreds of duplicates and drawings received from Schlechter, and later Mansfeld, before the tragic bombing of the Berlin herbarium in 1943.

With time, Ames became instrumental in providing his German counterpart with information about tropical American orchids: over fifteen years he exchanged duplicates from his Central and South-American herbarium specimens with Schlechter. One could say that during important periods of their work on orchids, Ames and Schlechter became indispensable to each other.

The first record of Schlechter's correspondence with Ames (August 3, 1908, from camp on Mount Komi, in what is now Papua New Guinea) is a letter in which he wrote: "I dare say I will be able to let you have a rather large number of Orchid specimens from here after my return to Europe and hope that you will have to offer some Orchid-material from TropicalAmerica in return, or perhaps the West-Indies?". It is the first mention of Schlechter's growing interest in the orchids of the New World tropics. A few months later, back in Germany, Schlechter wrote again (from Berlin, February 2, 1909) "I wish some American collectors would go to Venezuela and Columbia, there would be a fine harvest to be got. Perhaps they are leaving it to me yet [...] If ever you visit Berlin when I am there you will most probably be astonished to find there in my possession an Orchid-Herbarium which as to number of specimens and condition of them especially can well rival with these of big public institutions, as from all my travels I have brought drawings of nearly all species I got hold of. As I got most old world countries pretty well represented now in my herbarium I am very anxious to get especially Tropical-American and am very pleased to exchange with you any material you can spare from Central- and South America as well as the West-Indies. [...] Perhaps after a few years I will make a trip to Tropical America myself to get things better from there. However, this is not quite certain

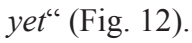

And then again (from Berlin, December 2, 1910): "I am very keen on any material from Central- or South America, as these countries are not well represented in my herbarium. [...] ... you can perhaps get me NewWorld-Orchids."

Shortly after this letter Schlechter finally started to work on South-American orchids. In yet another letter, this time from Riga (Latvia), on August 27, 1912, he told Ames: "At present I got some larger collections from South-America, Madagascar and Borneo to go through."

From 1910 the years immediately preceding WWI were immensely productive: Schlechter published a total of 22 papers in which he described South American orchids. As to Ames, Schlechter's last letter to him before the war was dated May 10, 1914. He would not write again until Aug. 31, 1919.

A fortunate event for Schlechter was the publication by botanist Friedrich Karl Georg Fedde (1873-1942) (Fig. 13) of a long series of booklets under the general title Repertorium specierum novarum regni vegetabilis (Fig. 14A). 


\section{A \\ Repertorium novarum specierum regni vegetabilis}

\author{
Centralblatt für Sammlung und Veröffentlichung \\ von Einzeldiagnosen neuer Pflanzen
}

anctore

Friderico Fedde

Fascieulus III (1906/7)

Mo. Bot Cercen

BERLIN-WILMERSDORF

SELBSTVERLAG DES HERAUBGEBERS, WEIMARSCHESTR 31

COMMISSIONS-VERLAG VON GEBRCDFR BORNTRAEGER, BERLIN $-1907-$

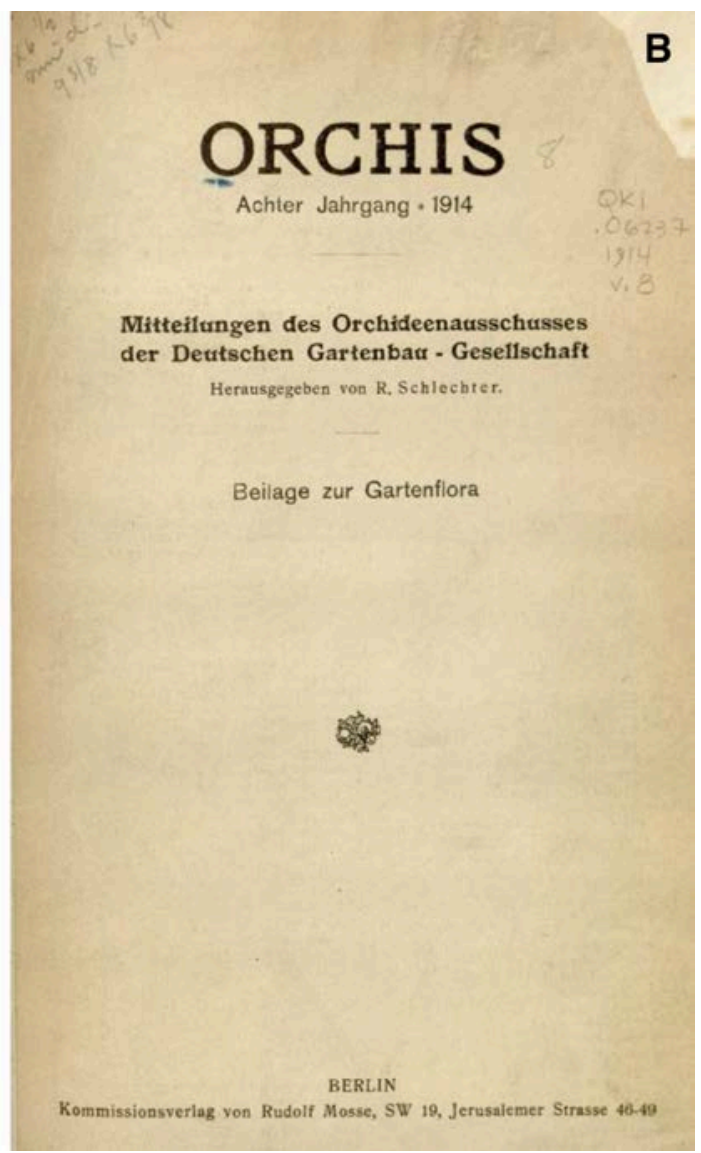

B

Mitteilungen des Orchideenausschusses

Beilage zur Gartenflora

BERLIN

Figure 14. A - Title page of Fedde's Repertorium Specierum Novarum Regni Vegetabilis. B - Title page of Orchis.

Fedde studied natural sciences, beginning in 1892 and graduating in 1896 in Breslau. After working as a teacher in schools of higher learning in several German cities, he became an associate at the Berlin Botanical Museum in 1901 and a professor there in 1912. Fedde took part in several collecting trips to Southern Europe, Finland, and South Russia. Beginning in 1910, Fedde would publish most of Schlechter's works until the latter's death in 1925. Among the first publications by Fedde were Schlechter's well-known series of articles: Orchidaceae novae et criticae. In 21 of these articles Schlechter described, among others, an important number of new South-American orchid species.

The second most important journal that published Schlechter's works was Orchis (Fig. 14B) (published from Vol.3, 1909, as part [Beilage] of the journal Gartenflora), the monthly journal of the German Orchidological Society, from 1906 until its disappearance in 1920, which was edited by Schlechter himself. A total of 31 of his articles were published in this periodical, among them his long series entitled Neue und seltene Garten-Orchideen (New and rare garden orchids), in which he described dozens of new orchids from Tropical America.

By 1914 Schlechter had already formed a 'network' of collaborators who supplied him with orchid species for determination. At first, his relations were with important orchid growers and collectors in Germany, such as Karl Wilhelm John in Andernach-on-the Rhine, Otto Beyrodt in Marienfelde, the Gardens of Herrenhausen in Hannover, Julius Wrede in BerlinDahlem, Wilhelm Hennis in Hildesheim and Baron Max von Fürstenberg, owner of an orchid collection and President of the recently founded German Society of Orchidology. From Ireland, he received plants from Frederic W. Moore, curator of the Botanic Gardens in Glasnevin. The legacy of Friedrich Carl Lehmann, the German plant collector in Colombia who had died 

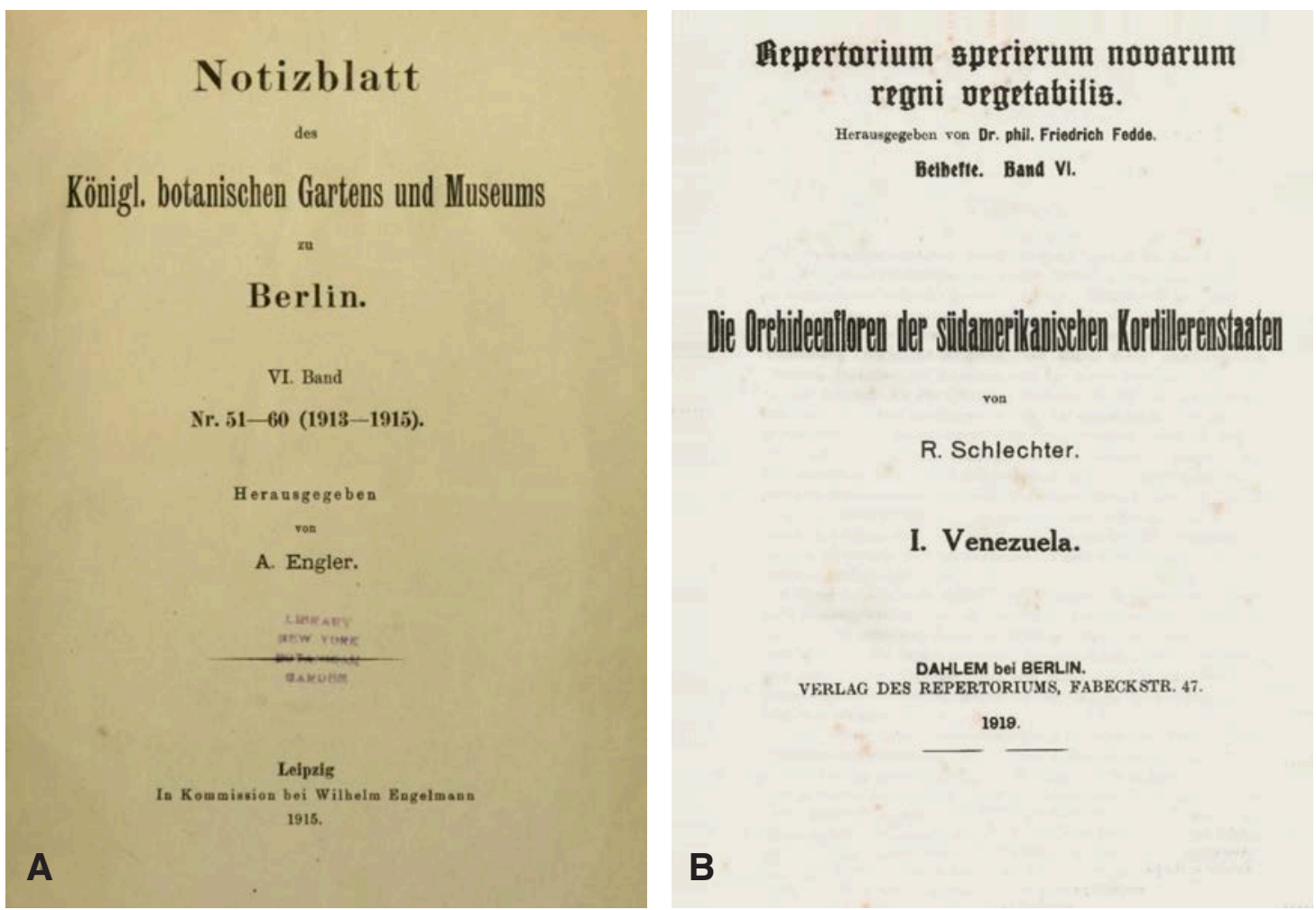

FiguRE 15. A - Title page of Notizblatt des Königlichen Botanischen Gartens und Museums zu Berlin. B - Title page of Volume I of Schlechter's Orchideenfloren der Kordillerenstaaten, volume I (Venezuela).

in 1903, was another important source of research material. Contact with Oakes Ames at Harvard again gave him the opportunity to receive more SouthAmerican material through the exchange of his African and Asian duplicates.

Among the first collectors on American soil from whom he received plants were Ernst Ule, who collected in Brazil, Guayana, Venezuela and Peru, Christian Theodor Koch (Brazil, Colombia, Venezuela), Eugène Langlassé (Colombia), Henrik Franz Alexander von Eggers (Ecuador), Eugene Köhler (Peru), Carl Pflanz (Bolivia), Otto August Buchtien (Bolivia), Robert Statham Williams (Bolivia), Karl August Gustav Fiebrig (Bolivia, Paraguay), Henri François Pittier (Venezuela, Colombia), Theodor Carl Julius Herzog (Bolivia, Argentina), Louis Mille and Luigi Aloysius Sodiro (Ecuador), Per Karl Haljmar Dusen (Brazil, Argentina, Chile, Paraguay), Georg Hans Emmo Hieronymus, and H. Wendt (Argentina, Brazil). Quite an impressive number of collectors and botanists, as one can see.
Despite having to serve in the military, Schlechter published an additional 28 papers in the period between 1914 and 1919, a remarkable number under the conditions in Germany during those years. Noteworthy from that time were Schlechter's monographic treatments on a number of orchid genera, among them Anguloa, Cycnoches, Coryanthes, Laelia, Acineta, Aganisia, Cochlioda, Houletia, and Brasssavola. Of great interest also was his second regional flora (after Mattogrosso in 1901), in which (1919) he determined Per Karl Dusen's orchid collections from the Brazilian province of Paraná. The Notizblatt des Königlichen ${ }^{7}$ Botanischen Gartens und Museums zu Berlin, edited by A. Engler (Fig. 15A) (in its later years, 1918-1924, after the abdication of Emperor Wilhelm II, simply Notizblatt des Botanischen Gartens und Museums zu Berlin) was another important means for Schlechter to see his works published.

\footnotetext{
Königlich $=$ Royal.
} 
Schlechter complained in several of his writings that because of the war he received very little new material from collectors in America. This explains the relatively small number of new species described by him during that period. Nevertheless, manynew names of orchid growers, collectors and botanists appeared in this period among Schlechter's orchid suppliers to expand his already important 'network'. Among them, we count orchid growers Paul Wolter in Magdeburg-Wilhelmsburg, R. Blossfeld in Potsdam and Hartmann in Nieder-Höchstadt; and the plant collectors Karl Immanuel Eberhard Ritter von Goebel (Brazil), Johann Heinrich Rudolf Schenck (Brazil), Emil Hassler (Paraguay, Guyana), and Carl Grossmann (Brazil).

Immediately after the war, Schlechter began to work on one of his most ambitious projects regarding the orchids of Tropical America: his series of publications about the orchid flora of the Andean states (Die Orchideenfloren der südamerikanischen Kordillerenstatten).

Communications across the Atlantic slowly resumed after the end of the war, and on August 31, 1919 Schlechter was once again able to correspond with Ames: "At last there is a chance again to communicate with foreign countries and so I will take a chance to try to send you a letter. [...] I expect the enumeration of the Central-American orchids will at present interest you most. But besides there is in print [...] an enumeration of the Orchid-Flora of Venezuela ... [...] The Orchid-flora of Venezuela is an enumeration of all the Orchids until now known from there! A number of new species I have added, and remarks on the features of the Orchid-flora. I have found that such compilations are of the greatest use and especially for the South-American Andes-states they were badly needed. [...] For Colombia, Ecuador, Peru and Bolivia the manuscripts are finished too and are going to be printed in the course of the next months. This work has considerable widened my knowledge of certain types, the more so as I have used the chances to study enormous materials more closely. ${ }^{8}[\ldots]$ After the publication of the Orchid-floras of the Andes-states we will have a fair knowledge of the distribution of the different types, the more so as I have been making remarks in the general part on the distribution of each species and the affinities of each flora."
Volume I of Schlechter's Orchideenfloren der Kordillerenstaaten (Fig. 15B) was finally published at the end of 1919. A number of new names were added to Schlechter's "network", among them Paul Rudolf Preuss, O.K.S. Passarge and Selwyn, Salomon Briceño, Everard Ferdinand Im Thurn, and F.V. McConnell and J.J. Quelch.

In the same letter of August 31, 1919, Schlechter described his personal difficulties in a country that was experiencing the trauma of the lost war: "the difficulties are numerous ones too, because now here in Germany the educated people are in comparison with the cost of daily life altogether underpaid and the costs of printing have risen to about four times the costs of before the war. I actually would best of all like to leave Germany and go somewhere else where one would have the chance to properly continue scientific work under more favorable circumstances. But perhaps things will develop yet again more favorably; until now I can't see very brightly into the future."

South American orchids became the center of Rudolf Schlechter's attention during the following months. In further letters to Ames he described the progress and difficulties of his project. So, on September 24, 1919: "For my winter work I had planned to determine the Colombian collections of the U.S. National Herbarium and of the New York Botanical Garden Herbarium. I wanted to do this work in order to get my set of Lehmann orchids ready for inclusion in my Herbarium. If your papers on the Colombian orchids are ready soon, please send them to me at your earliest convenience. They will save me the work of searching the literature for a list of Colombian species. I hope you have included, the numbers of specimens you have examined in these lists of yours and that you worked on the Lehmann collections."

October 22, 1919: "My list of Colombian Orchids is ready for print and I hope to bring the whole volume out before the end of the year. [...] I have described

8 Schlechter had studied the collections of Friedrich Lehmann from Colombia and Ecuador. Lehmann communicated with Professor H.G. Reichenbach f., the leading orchid taxonomist of the time, and after Reichenbach died in 1884, worked with Dr. F. Kraenzlin describing new species of orchids from Colombia and Ecuador. He also sent a large set of his collections to Kew, where many were identified by Robert A. Rolfe. 


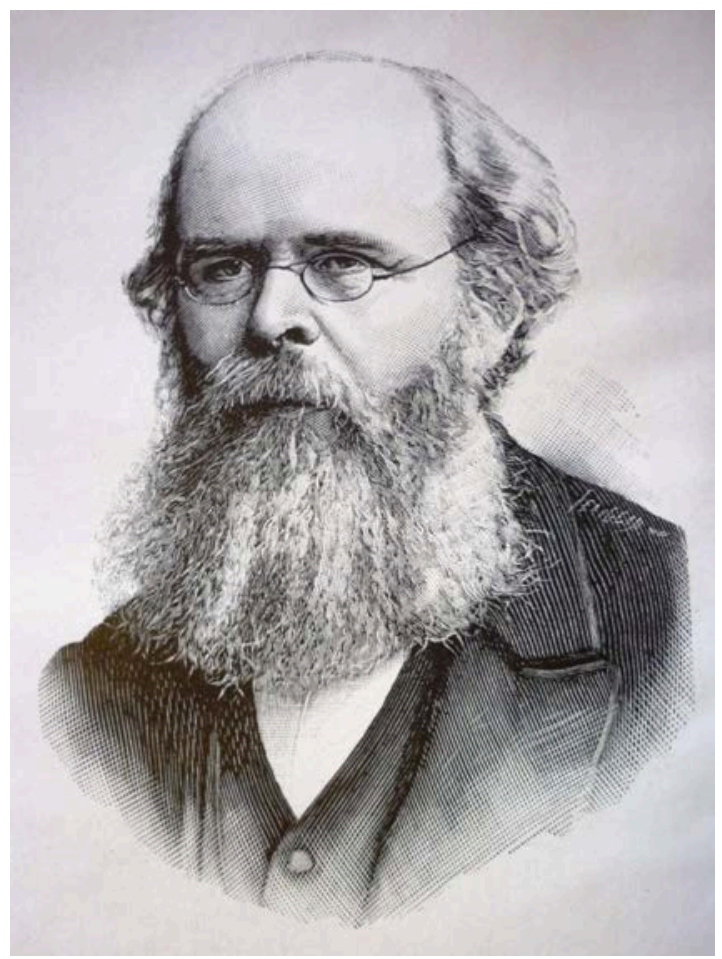

Figure 16. Celestin Alfred Cogniaux (1841-1916). Unknown author.

over 250 new Colombia Orchids and 5 or 6 new genera. Quite a lot of Lehmann's things are included and the plants from Sta. Martha collected by H.H. Smith... [...] the more we progress with the printing of the work the more difficulties we have got to get sufficient funds for the publications together. [...] Could you not perhaps interest some of the botanical circles in your country, that they might supply us with sufficient funds by suscribing for the publication of these lists? [...] These lists are going to be published in five parts under the title "Die Orchideenfloren der südamerikanischen Kordillerenstaaten" I. Venezuela, II, Colombia, III Ecuador, IV Peru, V. Bolivia."

An important role in Schlechter's "network" was played by Celestin Alfred Cogniaux (1841-1916) (Fig. 16), the great Belgian botanist and specialist on South American orchids. Cogniaux had worked for years with Adolf Engler (Director of the Berlin Botanical Garden between 1889 and 1921) and Ignaz Urban (1948-1931) (Fig. 4) (Assistant Director of the Berlin Botanical Garden and Museum from 1889 to 1913), being in charge of the Orchidaceae in the monumental Flora Brasiliensis and later the not less important Symbolae Antillanae seu fundamenta Florae Indiae Occidentalis. Engler and Urban also had close working relations with Rudolf Schlechter. Therefore, when Cogniaux had to retire because of his age and health ${ }^{9}$, Schlechter took over as his logical successor, describing the Orchidaceae in volume VII (fascicle IV, August 1913) and volume VIII (fascicle I, February 1920) of the Symbolae Antillanae. Thus, on November 11, 1919, Schlechter was able to write to Ames: "I have not made a list of the Lehmann determinations, but Cogniaux before he died has sent me, as he wished that I should continue his work on the SouthAmerican orchids, a book in which he had entered all the determinations that he has found of the different collectors in literature and that he made himself."

In the above-mentioned letter of August 31, 1919, Schlechter proposed to Ames that they take part in a new, ambitious project: a new and updated version of John Lindley's famous work, Folia Orchidaceae ${ }^{10}$ : "In fact, I very much hope that we will do yet a lot of work under combined authorship. I am much reckoning on you for the eventual cooperation on the 'Folia Orchidaceae', because as such I would think it best to bring out a future monograph of the Orchidaceae. This has the advantage that one can choose the genera as one has got material for the work."

Schlechter wrote to Ames several times about this idea until, after months of impatient pressure, on April 23, 1920, Ames finally replied: "I am very much interested in the new 'FOLIA'. I would enjoy working with you, although I am afraid that the difference in our speed would throw the bulk of the labor on your shoulders. I am an intermittent worker; that is I am a slave of inclination, and there are months at a stretch when I find botanical work of any kind a perfected form of torture. You might not enjoy collaboration with a man who wanders from the job. [...] I have in mind a painstaking, thorough job of each genus or section of a genus we attack. [...] Although we would of course

9 In 1901 Cogniaux had retired from his chair in Natural History at Verviers on a pension, which enabled him to devote the whole of his time to botany. His latest completed work was on the orchids of the West Indies, which came out in volume VI of the Symbolae Antillanae.

${ }^{10}$ Lindley, J. 1852-1859. Folia Orchidacea. An Enumeration of the Known Species of Orchids. 
work independently on the genera we undertook to do, we ought to agree at the beginning that we would submit our manuscript to the other man before final going to the press [...]." This however could not stop Schlechter, who replied on May 9, 1920: "What you write about your own way of working intermittently cannot hinder us. I am myself, this I know, a fairly hard worker and will see to it that the work progresses. It is my ambition, and I hope it will be yours too, that we should be able to finish a monograph of all the Orchidaceae before our lives are finished. [...] For the title of the work I would propose 'Folia Orchidaceae' by Oakes Ames and R. Schlechter". And he continued: “... my plans are the following. We could work out the different genera separately, starting of course with the smallest ones, but at the same time bringing out now and then a larger one. The descriptions and the general way of publishing should be similar to the one adopted by Lindley, but each genus gets a systematical number, for which, as they are now fairly known, with slight alteration we could adapt the numbers as they are given in my book 'Die Orchideen'."

Meanwhile, Schlechter continued working and publishing on South American orchids. The remaining years of his short life (1919-1925) were at the same time among his most productive. A large number of his publications during that period made reference to South-American orchids. One of his most outstanding accomplishments was the completion of his series about the orchid floras of the Andean states, his famous Orchideenfloren der südamerikanischen Kordillerenstaaten.

The above-mentioned volume I (Venezuela, 1919) was followed in 1920 by volume II, Colombia; in 1921 by volumes III Ecuador and IV, Peru; and finally, in 1922, by volume V, Bolivia.

After finishing volume II, Schlechter ran out of funds for the remaining three volumes. Having received no answer to his petition to Ames of October 1919, Schlechter touched the same subject again on December 17, 1920: "As I have written to you already, my manuscripts with the compilations of the orchid floras of Ecuador, Peru and Bolivia are ready for print since a long time. Printing costs have however got so high here on account of our bad valuta, that Fedde has no funds to go on with the publication. [...] ...at the present state of our valuta this would roughly cost about 450 Dollars [...] Would it not be possible for you to help me in this matter by recommending me perhaps to some firm or by getting the suscriptions together?" On January $8^{\text {th }}, 1921$ Ames replied: "Now with regard to Dr. Fedde and the monographs of the orchids of Ecuador, Bolivia, etc. I can advance $\$ 450$ out of my own pocket and if this suggestion meets with your approval let me know and I will send you the amount. If you approve of the suggestion perhaps you will see to it that I receive my copies on a very high grade of paper. I will give orders to have one hundred dollars sent to you to-morrow. When you receive this you can start printing and the balance will be forwarded when I hear from you that my suggestion is welcome. I am very anxious to help orchidology in every way and it is a great pleasure to hasten the monographs to which you have referred." The arrangement was confirmed after Schlechter had promised that the money would be well applied (January. 27, 1921), and so Schlechter was able to write in the epilogue of his Orchideenfloren (Bolivia, vol. V, 1922): "I was fortunate that Prof. Oakes Ames, in Boston, put at my disposal the means which guaranteed the completion of the printing of this work." Ames finally sent $\$ 210$ to Schlechter to begin printing, the rest came soon afterwards (Fig. 17).

Ames and Schlechter's relationship lasted over the years and it was undoubtedly a fruitful one. While Ames had the economic means to pursue his interests, from which Schlechter drew great benefits, Schlechter was the higher botanical authority in this partnership. As an example of this, the International Plant Names Index from Kew Botanic Gardens (status April 2019) cites a total of 7,712 new species and combinations described by Schlechter, while for Oakes Ames it mentions just 1,627. Ames continuously sent orchid specimens to Berlin for determination, and Schlechter profited from Ames, who untiringly made the greatest efforts to procure new orchid specimens: In a letter dated June 25, 1921 Ames wrote: "I have just sent a collector to South America with the Mulford Biological Exploration Expedition to the Amazon basin ${ }^{11}$. This, I am sure will be good news for you as there will be a set of duplicates for your collection. As the expedition

${ }^{11}$ Ames refers to Orland Emile White (1885-1972) from the Brooklyn Botanic Garden, who was one of the two botanists of the expedition, assisted by Martin Cárdenas, a Bolivian botanist. 


\section{Memorandum Foreign Check Issued}

(Check should be sent by registered mail)
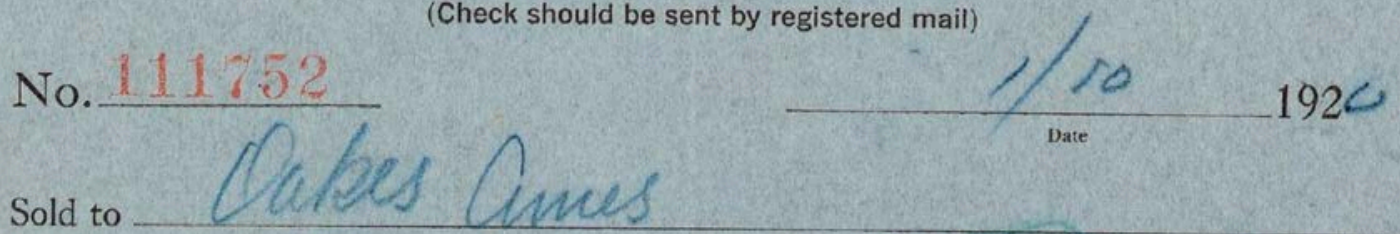

Sold to

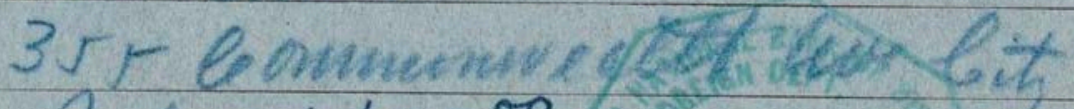

Address

Foreign Am't

tullot

Payee

Drawee

Bank

(1) 1448300

City
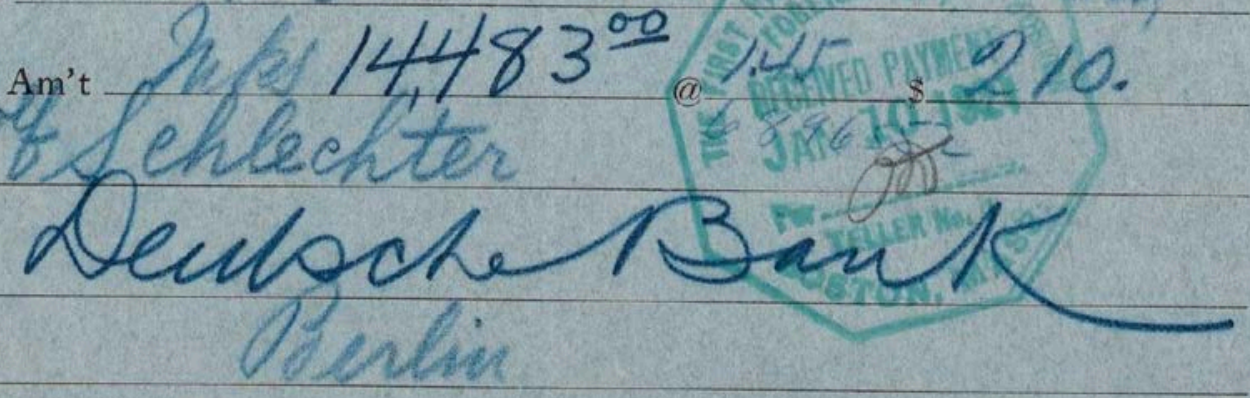

In duplicate

Yes - No

DeBIT

Cashier

Customer

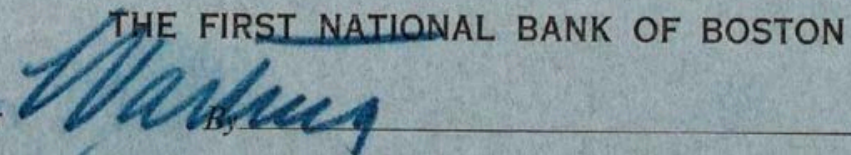

FiguRE 17. A - Carbon-copy of Ames’ check to Schlechter, Jan. 10, 1920 (\$210 U.S: Dollar equivalent to 4,483 German marks!).

\section{North Eastion, lass. Sełtember, 12, $192 \hat{1}$.}

Ny desr Dr. Sohleohter:

As a title fage is the first thing we must

agree on before we EO to press, I have started the ball rolling by

Futting together the following sugkestion. You areat liberty to

anplify or ohange it as you think beat.

\section{FOI TA OPCPTTACTEA}

A uotoribus

OAKFS ANES F'T RUDOTF ECHIFCHTER.

BOSTONI

YCNXXI.

FIgURE 18. Ames' proposed draft of a title page for the new "Folia Orchidacea". 
is to be in the field for fifteen months, most of the time in unexplored territory, there should he some new material for us." At the same time, work on the Folia Orchidaceae continued: on September 12, 1921, Ames sent a draft of his proposed title page for the Folia Orchidaceae: FOLIA ORCHIDACEAE / AUCTORIBUS / OAKES AMES ET RUDOLF SCHLECHTER / BOSTON / MCMXXI (Fig. 18).

In what would be his last trip outside of Germany, again financed by Ames, Schlechter spent two weeks at the Reichenbach Herbarium in Vienna, studying and making tracings of Reichenbach's orchid types from the Philippines.

In March of 1922 Ames made the decision to travel to Europe and meet Schlechter in person: "I want to let you know that I have decided to sail for England on June 28th, and that I am planning to be in Berlin either in July or August. I feel that we must discuss through some better medium than letters the details of our proposed undertaking, therefore I am coming to you, reluctantly on the one hand, eagerly, on the other. To leave home now means many sacrifices. But I cannot see how we can arrive at a working agreement without sitting face to face for a while. And, furthermore, the pleasure and profit of a meeting with you will repay me a thousandfold for the penalties of travel and the loss of results to be obtained by a summer of work at home."

In August of 1922, Ames arrived in Berlin and had finally the opportunity of meeting Rudolf Schlechter in person. Ames described the moment with these words: "In the Orchid Herbarium of Harvard University there is a watercolor drawing which represents a flower of Stanhopea Ruckeri. This drawing is, in my estimation, of unusual interest because the original specimen from which it was made was instrumental in introducing Schlechter to me in a crowded railroad station in Berlin (Fig. 19). At this time I lacked knowledge of what Schlechter looked like, and he was in complete ignorance of what I might look like. [...] As I walked along the platform I saw a man of medium height coming toward me, pushing his way slowly through the out-going crowd. He held a large spray of Stanhopea Ruckeri in his outstreched hand. It was not necessary for me to say: "Dr. Schlechter, I presume?", The glorious spray of Stanhopea Ruckeri was a flauntig badge of his identity" (Ames, 1944: 106).

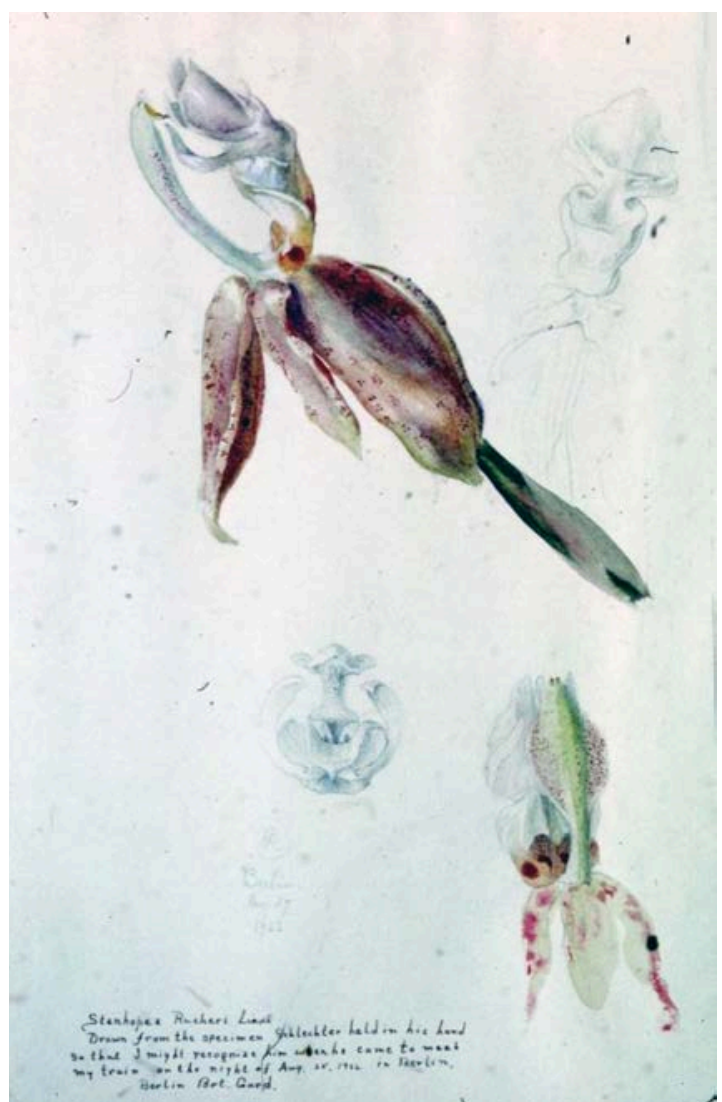

FIGURE 19. Stanhopea ruckeri. Watercolor in the Orchid

Herbarium of Harvard University. Archives of R. Jenny.

Meanwhile, Schlechter's 'network' continued growing as new names were added to the already long list of purveyors to his herbarium. Worthy of mention are: Albert William Bartlett (British Guiana), F. Schickendanz (Argentina), Wilhelm Gustav Franz Herter, Georg Huebner, Joao Geraldo Kuhlmann (Brazil), Herbert Huntington Smith, Erich (Eric) Bungeroth, H. Hopf, Werner Hopp, Gustav Schmidtchen, K. Sonntag, Richard Schnitter, M.A. Stübel, Wilhelm Kalbreyer (Colombia), E. K. Köhler, A. Köhler, Alexander Weberbauer, and Serafín Filomeno (Peru) and Jose Steinbach (Bolivia).

Back to the Folia Orchidaceae. Progress was seemingly slow. Impatiently, Schlechter wrote on November 25, 1922: "What about our 'Catalogue of Orchids', and what about the 'Folia'? I am very anxious to start." But Ames did not have good news for Schlechter. On December 14, 1922 he wrote:" [...] the present time seems very unpropitious for any 
heavy undertaking in the way of printing. [...] a few days ago I mailed to you a little pamphlet which I had privately printed because our magazines are very much hampered by the printing conditions in this country and by a falling off of subscriptions with increases in the cost to subscribers." The situation in the United States as well as in Germany did not improve, and the project of a new Folia Orchidacea was not mentioned again in Ames' and Schlechter's correspondence, a correspondence that slowly started to fade away. For the first time there appeared disagreement between the two botanists. In a letter dated December 16, 1923, Ames complained ${ }^{12}$ : "I am sorry that your remarks under Epidendrum ionophlebium on page 120, indicate that you regard my treatment of E. Hoffmannii as breach of trust. Before going to Europe in the summer of 1922, 1 devoted the greater part of the winter of 1921 to a critical and bibliographical study of Epidendrum, and it was at this time, not after my return from Europe, that I had arrived at the conclusions published in several numbers of Schedulae Orchidianae. [...] 1 have no desire to forestall you or to use your confidences for publication. If that spirit had governed my work I could have rushed into print with Powell's new species, long before you published your paper, because I had a nearly complete set from the Kew Herbarium in my possession at a time when Powell had given me every reason to be hostile."

A growing rivalry on Ames' part can be found in his correspondence with Charles H. Lankester (18791969) (Fig. 20), a British subject who had arrived in Costa Rica in 1900 and stayed in this country (with brief interruptions) until his death. Lankester began collecting orchids, of which Ames described over 100 species that were new to science. The same is the case in Ames' correspondence with Charles Wesley Powell (1854-1927), an American orchid collector from Panama's Canal Zone.

A few phrases from Ames' letters to Lankester give a good idea of how, in Ames' opinion, German botany in general and Schlechter in particular were endangering the supremacy of U.S. botany in tropical America: "We must work fast if we hope to keep

\footnotetext{
${ }_{12}$ Ames refers to Schlechter's publication of 1923, Additamenta ad Orchideologiam Costaricensem. Repertorium specierum novarum regni vegetabilis, XIX, Berlin.
}

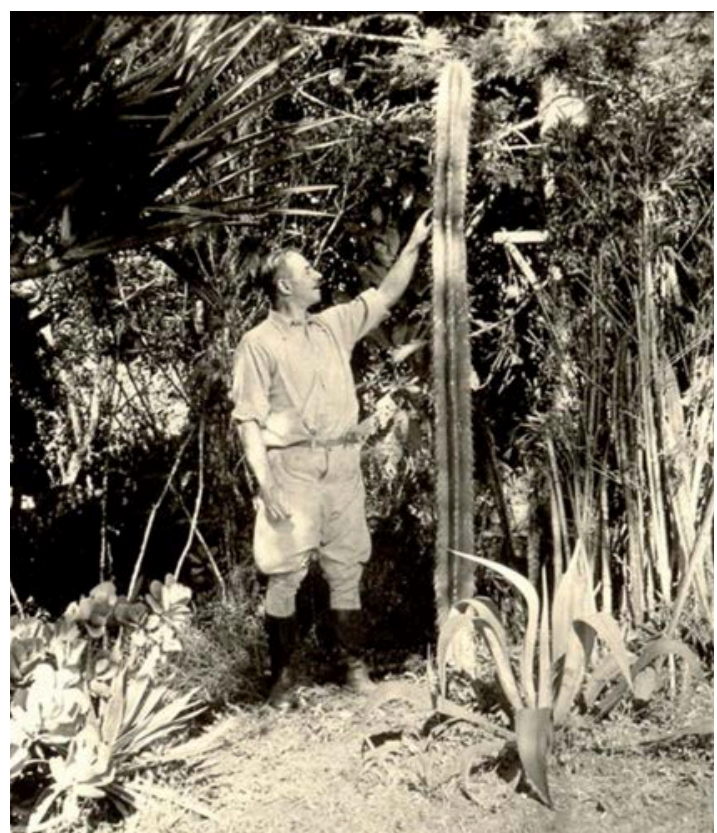

Figure 20. Charles H. Lankester (1879-1969) in his farm in

Costa Rica. Courtesy of Ricardo Lankester.

abreast of the Germans. I was surprised to see how far reaching their efforts have been to secure a monopoly of tropical American species" (Sept. 17, 1922) .... "If you decide to make specimens for me, please begin as soon as possible. Time is very precious" (October 10, 1922). "I wish we could get out another number of Sched. Orch. based on your work. We might beat Schlechter and give him food for thought" (May 28, 1923).

As to his correspondence with Powell, Ames wrote on September 14, 1921: "I understand that, you are now sending specimens to Rudolf Schlechter of Berlin. Although Dr. Schlechter and I are colleagues and at this time are working jointly on a monograph of the orchids of the world, it seems to me too bad that American material should be sent abroad. We surely can do the work in this country and I intend to do my best to handle material that is sent in to me for determination. Now that my poor friend Rolfe has gone I feel that it is my duty to do my best to keep up orchidology for English speaking people, not that I think for a minute that science is national, but that I dread to contemplate the future if our types are to be buried in a foreign land." To which Powell replied on October 10: "Before replying to the main questions 
in your letter of the 14th I wish to clear myself of the unsaid, but the implied charge of unpatriotism in sending my specimens to Europe instead of to the U.S. I am a native of Virginia and my forbears have a recorded and traceable history in that State since the year 1635, hence I could not be unpatriotic."

The misunderstanding was soon forgotten, but Ames used every opportunity to keep Powell aware of the German competition. December 12, 1922: "I wish we could keep Schlechter out of the American field. Otherwise there is bound to be a great deal of confusion owing to the simultaneous publication of species. I hope you will come to agree with me that it is for the best interests of American science to dissuade correspondents from sending material to Berlin." Powell replied on December 20: "After about a week I will write Dr Schlechter telling him of our new arrangement, and that under it I feel that I am under the obligation to send all future specimens to you. This will give him time to receive my letter of today with the money, and to put the matter in the hands of the printers. Thus insuring that he will not hold it up. Sub-rosa, I do not trust the Germans, not to engage in a little spite work." Ames had won the game. Powell enclosed a draft of the letter he intended to send to Schlechter: "My dear Dr Schlechter: I have entered into a contract with Dr Oakes Ames, of Boston, to make a complete orchideological survey of the Isthmus of Panama -he financing the undertaking. My men are now out going thither and yon in pursuit of this end. As it is incompatible with this contract that I should send any specimens from this time to any other person or garden than to him; specimens in future, can only be procured from him."

But these phrases can give us a wrong picture. In spite of the growing rivalry, Ames respected and admired Schlechter throughout his life. Let us see other expressions, again in Ames' correspondence with Lankester: "From the South of France, Col. Godfrey writes that Schlechter is seriously ill... I have not heard from Schlechter for over four months, and I had begun to fear that he was angry or in some way provoked by some act of mine" (March 23, 1924).

Personal circumstances on both sides gave additional motives for the lack of communication between Ames and Schlechter, especially during the year of 1924. On April 8, Schlechter explained: "I had already for some time the intention to write to you. My serious illness and feebleness has been preventing me from doing it before now. [...] It was not only the sickness that gave me the knock-out, but also the whole financial disaster, which made us loose nearly everything that one has had." And Ames had reasons of his own, as he made clear on January 20, 1925: "My co-trustee in the estate created by my father, suddenly and unexpectedly, committed suicide, about the middle of September. This sad event threw on my shoulders the full burden of business that is essential to my family. I had to begin the disagreeable task of spending most of my time in the city and in offices."

Finally, on December 3, 1925 came the tragic news. Ames wrote to Lankester: "I should not have begun this letter with a reference to myself. I should have expressed to you my deep sorrow at the news that came in this noon from Alexandra Schlechter. Schlechter died early in November. I had known of his illness and on the ninth of December I sent aid to Mrs. Schlechter to meet the heavy burden of a hospital bill. But I had been led to believe that there were hopes for recovery. What a place the old world is. There comes a time when death plays round us like heat lightning. And then it begins to thin the ranks of those we called friends. It is a wonder we are able to carry on."

During the last years of Schlechter's life, Ames received duplicates from Schlechter's orchids (Fig. 21 ), and carried the cost of having pencil tracings made from a great number of Schlechter's orchid types. It is due to this fortunate decision that an important part of Schlechter's material was preserved and saved from the destruction of the Berlin Herbarium in 1943. Hundreds of drawings were prepared under Schlechter's supervision. His wife, Alexandra, took over after his death, and continued arranging to have new tracings made according to Ames' indications (Fig. 22-23A-B). In Oakes Ames' last letter to Alexandra Schlechter, in the Harvard files, dated February 14, 1926, he wrote: "I can not thank you enough for the tracings of Stelis and Pleurothallis. These are a valuable addition to my herbarium and give me just the information I need to facilitate any work on the Costa Rican orchid flora. I have a long list of other species regarding which I would like 

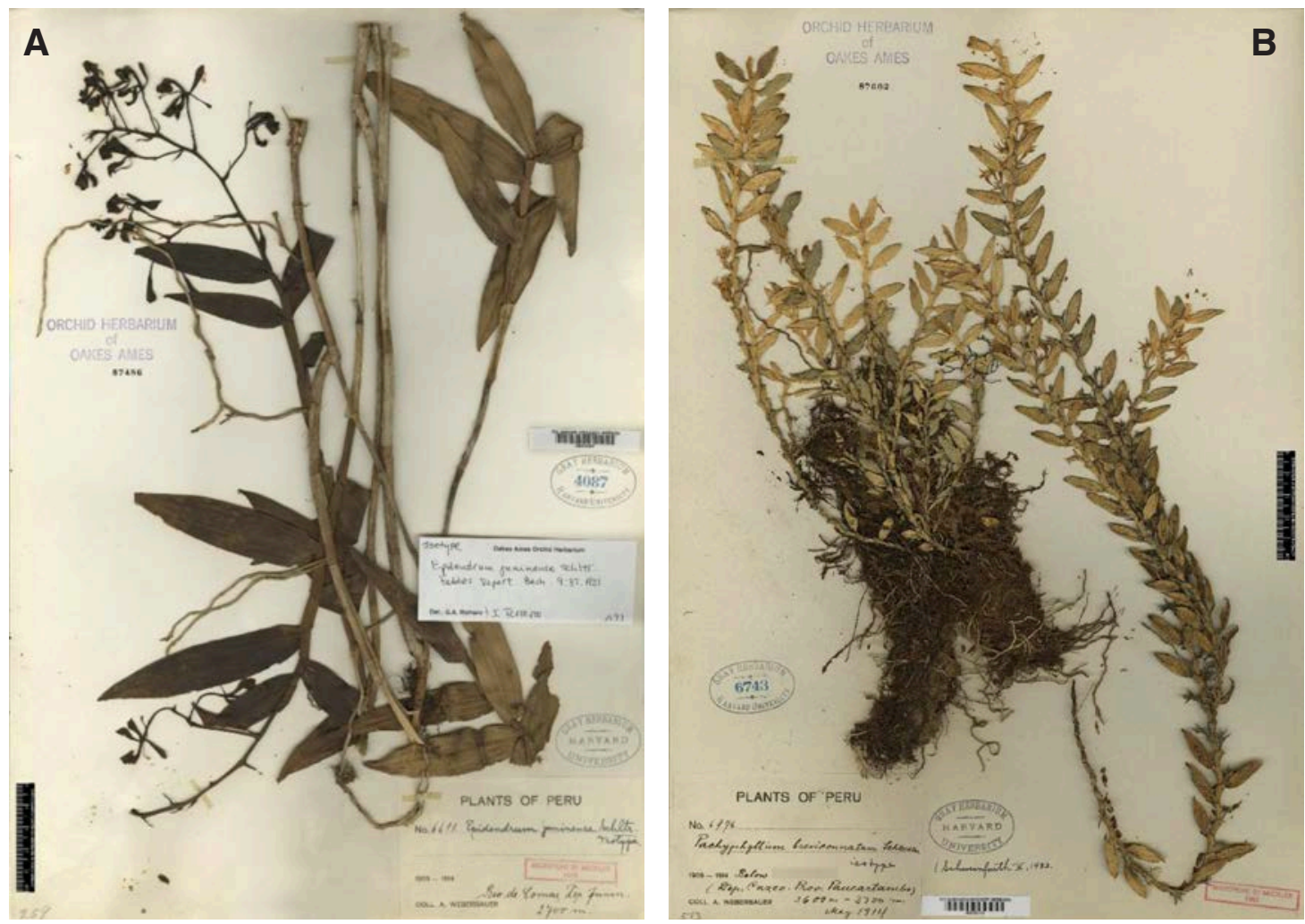

FIgURE 21. A - Isotype of Epidendrum juninense Schltr., presently at the Oakes Ames Orchid Herbarium. Originally

collectyed by A. Weberbauer in Peru. B - Isotype of Pachyphyllum breviconnatum Schltr., presently at the Oakes Ames

Orchid Herbarium. Originally collected by A. Weberbauer in Peru.

to have similar information. Would it be too much to ask of you, that you have tracings of then made? Without tracings it will be difficult to ascertain the finer details which are essential for satisfactory work. Please help me if you can. I have underlined the species which are important so that you can select the ones to do first." The letter ends with a several-pages-long list containing Ames' desiderata. In her last recorded letter of June 25, 1926, Alexandra answers: "I am very glad to hear the first tracings reached you safely and have found your approval. I hope by now you received the second letter with the rest of the drawings. I am happy to having been able to do something for you."

Other images of Schlechter's herbarium were preserved in a unique type photograph collection housed in the Field Museum of Natural History in Chicago. The collection originated in 1929, when James Francis Macbride, funded by the Rockefeller Foundation, traveled to Europe to photograph herbarium specimens of nomenclatural types. The intent was to make the photographs available to American botanists unable to finance travels to European herbaria; the widespread adoption of the loan process was not as fully developed as it is today, necessitating travel for consultation.

Over a ten years, Macbride photographed type specimens of tropical American plants at the following major herbaria: Berlin, Copenhagen, Geneva, Hanover, Hamburg, Madrid, Munich, Paris, and Vienna, using Berlin-Dahlem and Geneva as bases of operation. His sojourn in Europe resulted in more than 40,000 photographic negatives. Duplicate collections, types, and type fragments of authentic material were selected and sent to The Field Museum as exchange (Fig. 23C$\mathrm{D}, 24)$. The results were of immediate importance to American systematic botany, but acquired added meaning following the destruction of parts of some European herbaria during World War II (Field Museum of Natural History 2018). 


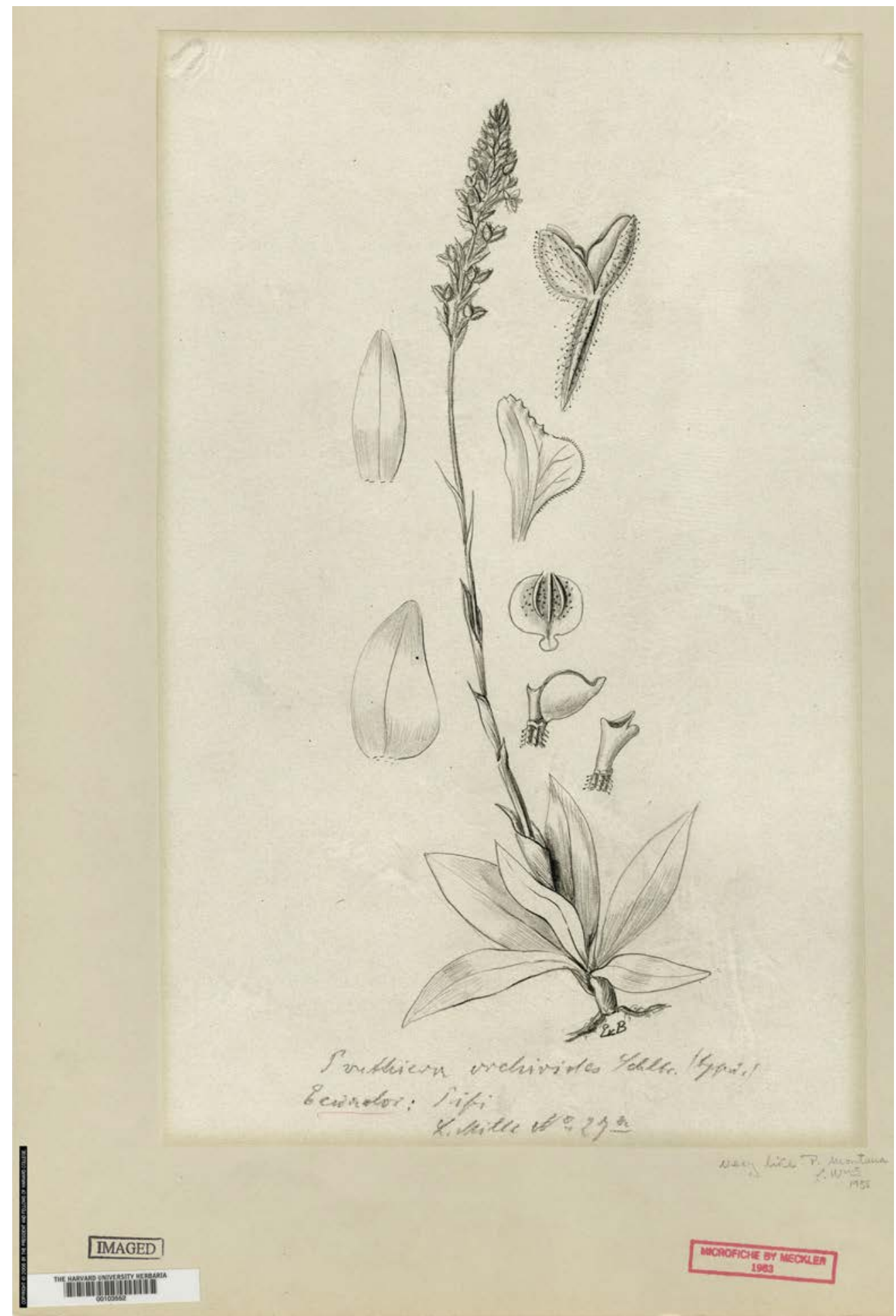

Figure 22. Drawing at the Oakes Ames Herbarium, prepared under Schlechter's supervision, of the type of Ponthieva orchioides Schltr. Originally collected by L. Mille in Ecuador. 

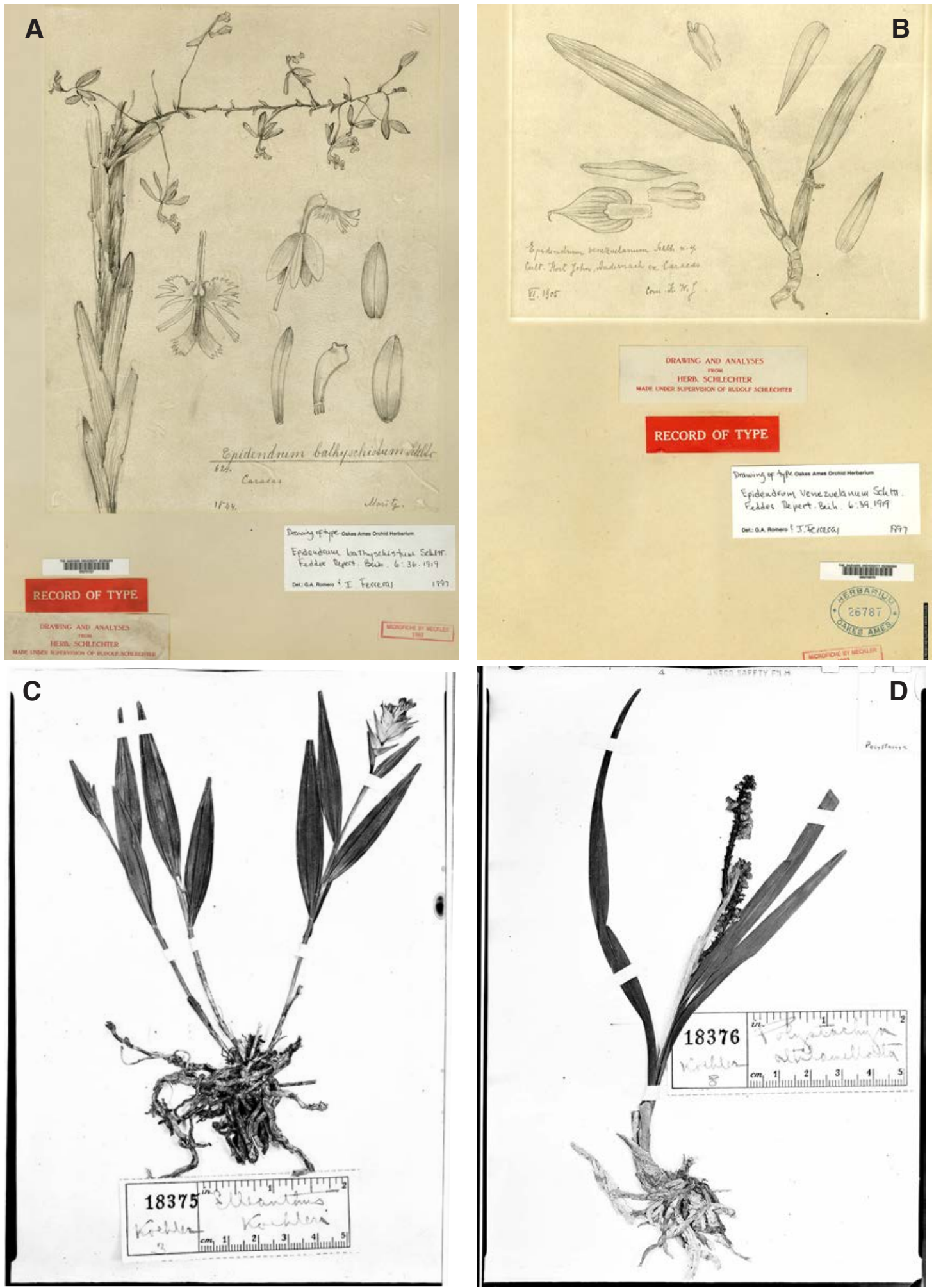

LANKESTERIANA 19(2). 2019. (C) Universidad de Costa Rica, 2019 


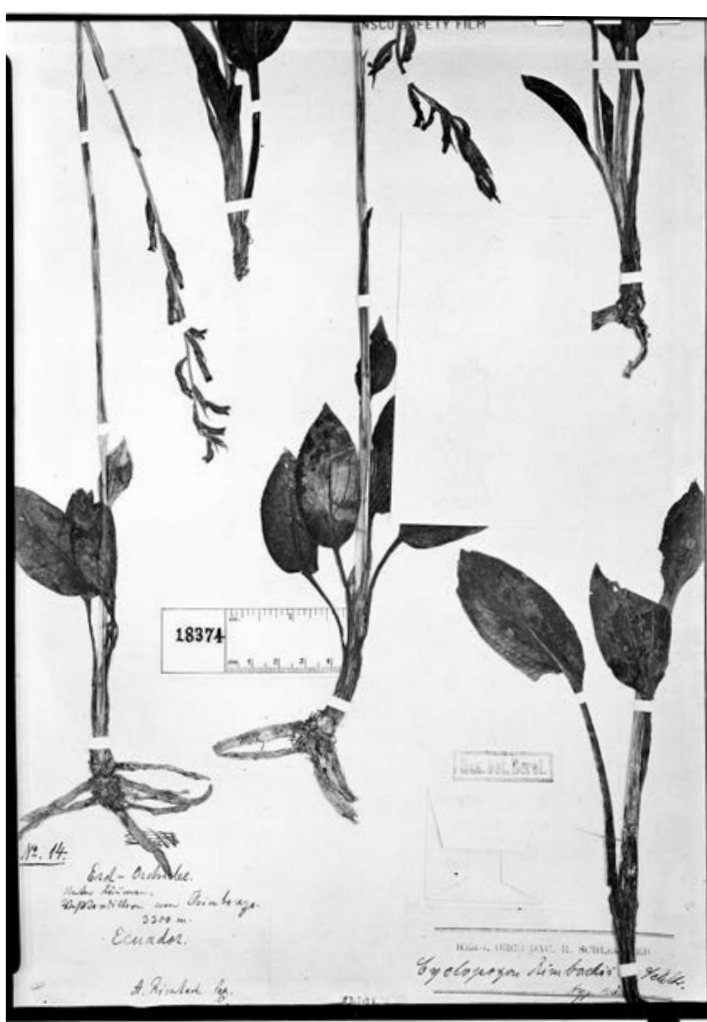

Figure 24. Cyclopogon rimbachii Schltr. Photograph of the type by J.F. Macbride. Field Museum of Natural History, Chicago. Collected by A. Rimbach in Ecuador.

Finally, additional photographs and some pages of Schlechter's original type-written manuscripts with the description of new species have been preserved, i.e. at the Geneva Delessert Herbarium.

After Schlechter's death Rudolf Mansfeld (19011960) (Fig. 25) edited a Figuren-Atlas (Fig. 26-27). It contained 558 analytical drawings in 142 plates of South American orchids new to science and described by Schlechter in the five volumes of his Orchideenfloren der Kordillerenstaaten; a further proof of his incredible capacity of work. Mansfeld was for over twenty years curator of the Botanical Garden and Museum of BerlinDahlem, where he specialized in orchids and was responsible for the publication of several of Schlechter's

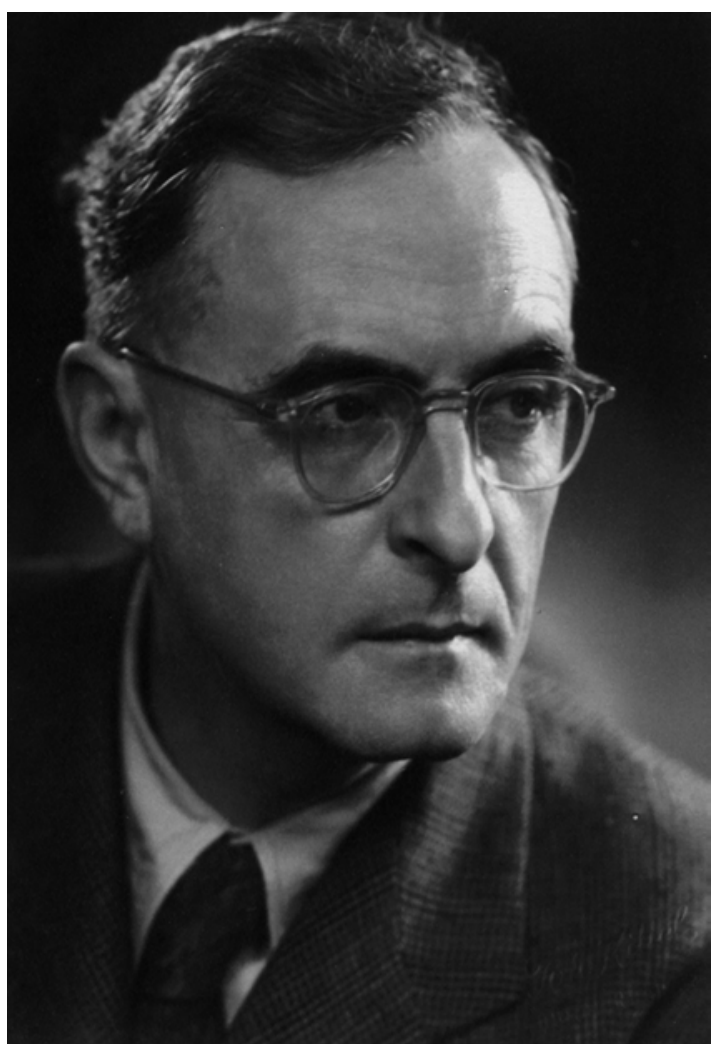

Figure 25. Rudolf Mansfeld (1901-1960). Archives of Rudolf Jenny.

unfinished works. In 1937 he suggested a revision of Schlechter's system ${ }^{13}$. Mansfeld's ideas were, however, largely ignored by the users of Schlechter's system.

The deaths of Celestin A. Cogniaux in 1916 and of Robert A. Rolfe in 1921, followed by that of Schlechter in 1925, marked the beginning of the decline in European orchidology. Europe's dominant position was slowly replaced by that of the United States, led by Oakes Ames, and by over a dozen formidable botanists and botanical institutions during the rest of the 20th century.

\footnotetext{
${ }^{13}$ Mansfeld, R. 1937. Uber das System der OrchidaceaeMonandrae. Notizblatt des Koniglichen Bot. Gartens \& Museums zu Berlin-Dahlem 13: 666-676.
}

Left, Figure 23. A - Drawing at the Oakes Ames Herbarium, prepared under Schlechter's supervision, of the type of Epidendrum bathyschistum Schltr. Originally collected by Moritz in Venezuela. The label reads: Drawing and Analyses from Herb. Schlechter. Made under supervision of Rudolf Schlechter. B - Drawing at the Oakes Ames Herbarium, prepared under Schlechter's supervision, of the type of Epidendrum venezuelanum Schltr. Originally collected by K. W. John. C - Elleanthus koehleri Schltr. D - Polystachya altilamellata Schltr. C, D: photographs of the types by J.F. Macbride. Field Museum of Natural History, Chicago. Both collected by E. Koehler in Peru. 


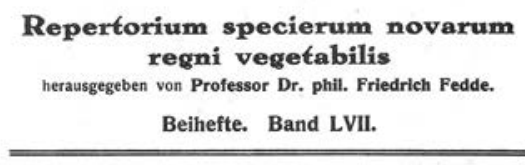

Figuren=Atlas

zu den

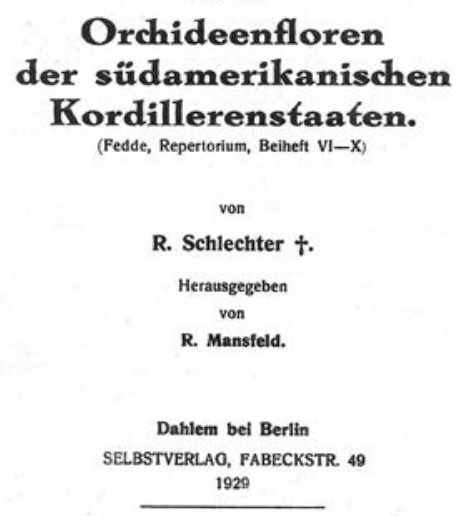

FIGURE 26. Title page of Schlechter's Figuren-Atlas.

Rudolf Schlechter's publications on South American Orchidaceae. The following is a list of the complete publications by Rudolf Schlechter on the Orchidaceae of South America. The list is organized by countries, and divided in two sections: 1) national and regional orchid floras, specific collectors; 2) publications on specific orchid tribes and subtribes, genera or species. Within each country, the publications are in chronological order. In addition,

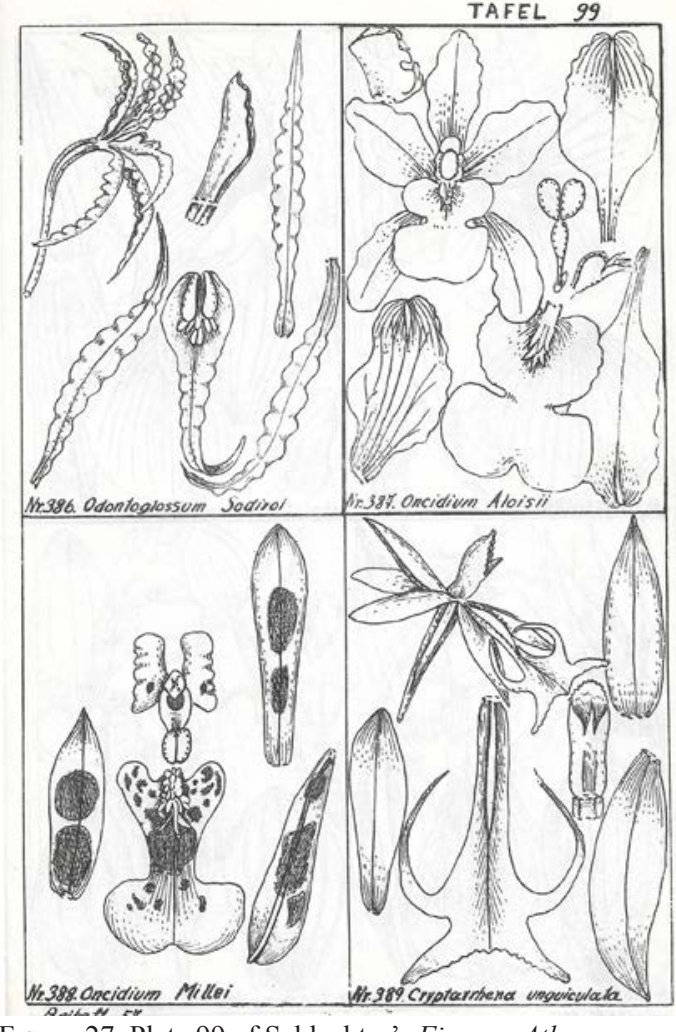

Figure 27. Plate 99 of Schlechter's Figuren-Atlas.

Schlechter's collectors and other members of his 'network' are listed. Finally, we show the genera and species new to science described by Schlechter from each of the South American countries. Probably neither list, whether of publications, collectors or plant names, is complete. Although the authors have made all efforts researching in available material, one or the other name, or publication, may have escaped their attention.

\section{BrazIL (Fig. 28)}

\section{National and regional orchid floras, specific collectors}

1901 Schlechter, R. Orchidaceae. In Pilger, R. Beitrag zur Flora von Mattogrosso. Botanischer Bericht über die Expedition von Dr. Herrmann Meyer nach Central-Brasilien 1899. Botanische Jahrbücher für Systematik, Pflanzengeschichte und Pflanzengeographie 30: 149-150.

1914 Schlechter, R. Orchidaceae. In Pilger, R. Plantae Uleanae novae vel minus cognitae. Notizblatt des Königlichen Botanischen Gartens und Museums zu Berlin, Vol. 6: 120-126.

1919-1920 Schlechter, R. Orchidaceae novae et criticae, Decas LXX (Additamenta ad Orchideologiam Brasiliensem). Repertorium specierum novarum regni vegetabilis, Vol.17: 267-272.

Schlechter, R. Beiträge zur Kenntnis der Orchidaceenflora von Paraná. Repertorium specierum novarum regni vegetabilis., Vol. 35: 1-108. 


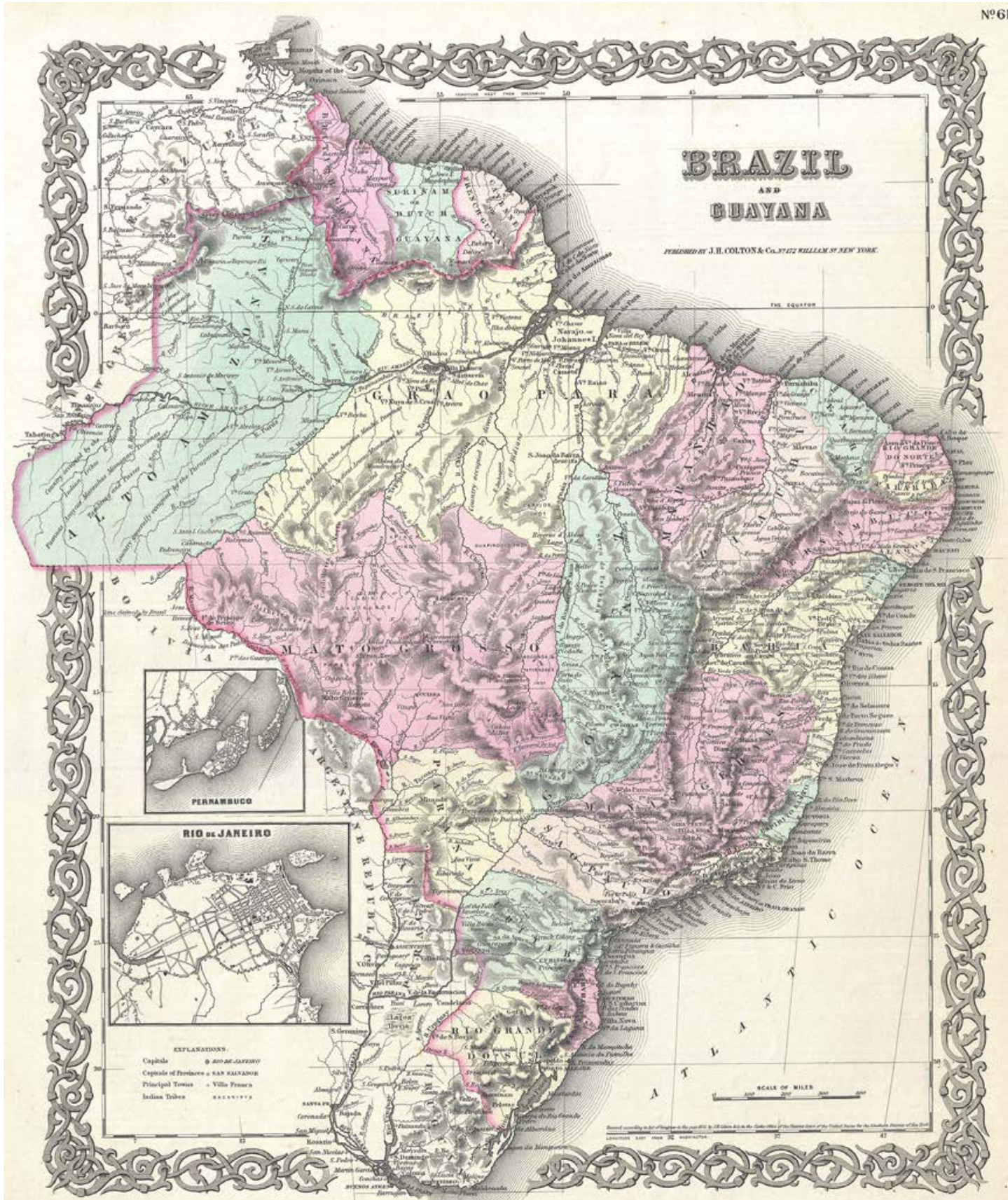

Figure 28. Map of Brazil and the Guyanas, 1855. Colton's Atlas of the World Illustrating Physical and Political Geography, Vol 1, New York.

1922 Schlechter, R. \& Hoehne, F.C. Contribuções ao Conhecimento das Orchidáceas do Brasil. Anexos das Memorias do Instituto de Butantan: Seccao de Botanica 1(2): 5-48.

1922 Schlechter, R. Über einige interessante, neue Orchidaceen Brasiliens. Archivos do Jardim Botanico do Rio de Janeiro, vol. 3: 289-293. 
1925 Schlechter, R. Die Orchideenflora von Rio Grande do Sul. Repertorium specierum novarum regni vegetabilis., Vol. 35: $1-108$.

Schlechter, R. Beitraege zur Orchideenkunde des Amazonas-Gebietes, I. Orchidaceae Kuhlmannianae; II. Orchidaceae Huebenerianae. Repertorium specierum novarum regni vegetabilis., Vol. 42: 67-82; 82-150.

1926 Schlechter, R. Beiträge zur Kenntnis der Orchidaceenflora von Parana. II. Orchidaceae Hatschbachianae. Repertorium specierum novarum regni vegetabilis, Vol. 23: 32-71.

Schlechter, R. \& Hoehne, F.C. Contribuções ao Conhecimento das Orchidáceas do Brasil. Archivos de Botânica do São Paulo 1: 203-216.

1929 Schlechter, R. Einige neue Orchideen des Itatiaya (Brasilien). Repertorium specierum novarum regni vegetabilis, Vol. 27: 296-301.

1940-1945 Hoehne, F.C. Flora Brasilica. Vol. 12(2): 378. Graphicars, Romiti \& Lanzara, São Paulo.

\section{Specific orchid tribes and subtribes, genera or species}

1906 Schlechter, R. Ueber einige neue Orchidaceen. Orchis, Monatsschrift der Deutschen Gesellschaft für Orchideenkunde, Vol.1: 4-6.

Schlechter, R. Über eine neue Bifrenaria. Orchis, Monatsschrift der Deutschen Gesellschaft für Orchideenkunde, Vol.1, 1906-1907: 25

1910 Schlechter, R. Orchidaceae novae et criticae, Decas XI. Repertorium specierum novarum regni vegetabilis., Vol. 8: 453. Schlechter, R. Orchidaceae novae et criticae, Decas XIV-XV. Repertorium specierum novarum regni vegetabilis., Vol. 8: 561.

1912-1913 Schlechter, R. Orchidaceae novae et criticae, Decas $X X X V$. Repertorium specierum novarum regni vegetabilis., Vol.11: 41-47.

1914 Schlechter, R. Oncidium concolor Hook. und Oncidium ottonis Schltr., zwei nahe verwandte Arten. Orchis, Mitteilungen des Orchideenausschusses der Deutschen Gartenbau-Gesellschaft, vol. 8: 57-61.

Schlechter, R. Neu und seltene Gardenorchideen VI. Orchis, Mitteilungen des Orchideenausschusses der Deutschen Gartenbau-Gesellschaft, vol. 8: 131-137.

1915 Schlechter, R. Neue und seltene Garten-Orchideen, VII. Orchis, Monatsschrift der Deutschen Gesellschaft für Orchideenkunde, Vol. 9: 56-60.

1917 Schlechter, R. Eine neue Laelia-Art. Orchis, Monatsschrift der Deutschen Gesellschaft für Orchideenkunde, Vol.11: 72-74.

Schlechter, R. Über eine neue Stanhopea-Art. Notizblatt des Botanischen Gartens und Museums zu Berlin - Dahlem, Vol.6(62): 483-484.

1917-1919 Schlechter, R. Orchidaceae novae et criticae, Decas $L X V$. Repertorium specierum novarum regni vegetabilis, Vol. 16: 353-358.

1918 Schlechter. R. Orchidaceae novae, in caldariis Horti Dahlemensis cultae. Notizblatt des Botanischen Gartens und Museums zu Berlin-Dahlem, Vol.7 (66): 268-280.

Schlechter. R. Die Gattung Aganisia Ldl. und ihre Verwandten. Orchis, Monatsschrift der Deutschen Gesellschaft für Orchideenkunde, Vol. 12: 24-42.

Schlechter. R Die Gattung Restrepia H. B. u. Kth. Repertorium specierum novarum regni vegetabilis., Vol. 15: 255-270.

1919 Schlechter, R. Die Gattung Brassavola R. Br. Orchis, Monatsschrift der Deutschen Gesellschaft für Orchideenkunde, Vol. 13: 39-46; 56-62; 68-79.

Schlechter. R Orchidaceae novae, in caldariis Horti Dahlemensis cultae. II. Notizblatt des Botanischen Gartens und Museums zu Berlin-Dahlem, Vol.7 (66): 323-330.

1919-1920 Schlechter R. Studium zur Klärung der Gattung Rodriguezia Ruiz et Pav. Repertorium specierum novarum regni vegetabilis., Vol. 16: 416-417.

Schlechter. R. Orchidaceae novae et criticae, Decas LXVI-LXVII. Repertorium specierum novarum regni vegetabilis., Vol. 16: 437-450. 
1920 Schlechter, R. Versuch einer systematischen Neuordnung der Spiranthinae. Beihefte zum Botanischen Centralblatt. Zweite Abteilung, Systematik, Pflanzengeographie, angewandte Botanik 37(2): 317-454.

Schlechter, R. Orchidaceae novae et criticae, Decas LXVIII. Repertorium specierum novarum regni vegetabilis., Vol. 17: $12-18$.

1921 Schlechter, R. Orchidaceae novae et criticae, Decas LXX. Repertorium Specierum Novarum Regni Vegetabilis 17: $267-272$.

1921-1924 Schlechter, R. Orchidaceae novae, in caldariis Horti Dahlemensis cultae III. Notizblatt des Botanischen Gartens und Museums zu Berlin - Dahlem, Vol. 8: 117-126.

1925 Schlechter. R. Orchidaceae novae et criticae, Decas LXXVIII-LXXIX. Repertorium specierum novarum regni vegetabilis, Vol. 21: 330-343.

Schlechter's network in Brazil (orchid collectors, growers and other purveyors)

- Aquino, Franzisco (?), collected 1921-1922.

- Bello, O. (?), collected 1907.

- Blossfeld, Robert (1882-1945), orchid grower in Potsdam.

- Beyrodt, Otto (1879-1923). Orchid grower in Marienfelde, Germany, around 1900-1923.

- BornmüLler, Alfred (1868-1947), collected 1904-1907.

- Brade, Alexander Curt (1881-1871), collected 1910-1871.

- Burger, L. (?), collected 1922.

- Campos Porto, Paulo (1889-1968), collected 1917-1936.

- Christian, F. (?), collected ca. 1920.

- Czermak, Josef (?), collected 1897-1899

- Dusen, Per Karl Haljmar (1855-1856), collected 1895-1916.

- Dutra, João (1862-1939), collected 1925.

- Fürstenberg, Baron Max (Maximilian) von (1866-1925), owner of an orchid collection ca. 1900-1910.

- Gehrt, August (?), assistant to F.C. Hoehne, collected 1917.

- Goebel, Karl Immanuel Eberhard Ritter von (1855-1932), collected 1890-1913.

- Grossmann, Carl (?), collected 1903-1908.

- Hatschbach Sobrinho, Albino (1890-1974). collected 1919-1925.

- Hennis, Wilhelm (1856-1943), orchid grower in Hildesheim.

- Herter, Wilhelm Gustav Franz (1884-1958), collected 1913-1934.

- Hoenne, Frederico Carlos (1882-1959), collected 1911-1938.

- HüBnER, Georg August Eduard, (1862-1935), collected 1920-1929.

- John, Karl Wilhelm (?). Orchid grower in Andernach-on-the Rhine, Germany, around 1910.

- JÜrgens, Carlos (?), collected 1906-1921.

- Kley, Urbano (?), collected 1910-1920.

- Koch, Christian Theodor (1872-1924), collected 1904-1913.

- Kuhlmann, João Geraldo (1882-1948), collected 1912-1943.

- Lützelburg, Phillip von (1880-1948), collected 1913-1934.

- Magalhães Gomes, Carlos Thomas (1855-1944), collected 1894.

- MourA, Juliano Trajano (1867-?), collected 1888-1890. 
- Pilger, Robert Knud Friedrich (1876-1953), collected 1899-1900.

- ReINECK, Eduard Martin (1869-1931), collected 1899-1908.

- SCHENCK, Johann Heinrich Rudolf (1860-1927), collected 1886-1887.

- Schnittmeyer, Max (?), collected 1916.

- Schwacke, Karl August Wilhelm (1848-1904), collected 1889.

- Ule, Ernst Heinrich Georg (1854-1915), collected 1893-1912.

- Wendt, H. (?), collected 1907-1912.

- Wettstein, Richard (1863-1931), collected 1901.

- Zehntner, Leo (?), collected 1912.

Orchids described by R. Schlechter from Brazil (Dusen \& Schltr. / Schltr. \& Campos Porto / Hoehne \& Schltr./ Schltr. ex Hoehne/ Schltr. ex Mansf. / Schltr. ex Pabst, in some cases)

The following is a list of the orchids described by R. Schlechter as new to science from Brazil, as enumerated in the aforementioned bibliography (only basionyms):

\section{New orchid genera}

Centrogenium Schltr.

Cladobium Schltr.

Fractiunguis Schltr.

Huebneria Schltr.

Leaoa Schltr. \& Campos-Porto

Lyroglossa Schltr.

Mesadenus Schltr.

Aganisia brachypoda Schltr.

Bifrenaria fuerstenbergiana Schltr.

Bipinnula ctenopetala Schltr.

Brassavola multiflora Schltr.

Brassia angustilabia Schltr.

Brassia huebneri Schltr.

Brassia iguapoana Schltr.

Brachystele bracteosa Schltr.

Brachystele spiranthoides Schltr. ex Mansf.

Bulbophyllum paranaense Schltr.

Bulbophyllum perii Schltr.

Camaridium amazonicum Schltr.

Camaridium vandiforme Schltr.

Campylocentrum dutraei Schltr.

Campylocentrum hatschbachii Schltr.

Campylocentrum pubirhachis Schltr.

Campylocentrum zehntneri Schltr.

Capanemia angustilabia Schltr.

Capanemia hatschbachii Schltr.
Otostylis Schltr.

Pseudostelis Schltr.

Pteroglossa Schltr.

Rodrigueziopsis Schltr.

Tracheosiphon Schltr.

Xerorchis Schltr.

\section{New orchid species}

Capanemia juergensiana Schltr.

Capanemia paranaensis Schltr.

Capanemia perpusilla Schltr.

Catasetum appendiculatum Schltr.

Catasetum brachybulbon Schltr.

Catasetum colossus Schltr.

Catasetum huebneri Schltr.

Catasetum linguiferum Schltr.

Catasetum mocuranum Schltr.

Catasetum negrense Schltr.

Catasetum polydactylon Schltr.

Centrogenium macrophyllum Schltr.

Cleistes australis Schltr.

Cranichis bradei Schltr.

Cryptophoranthus dusenii Schltr.

Cryptophoranthus juergensii Schltr.

Cryptophoranthus similis Schltr.

Cyanaeorchis minor Schltr.

Cyclopogon aphyllus Schltr. 
Cyclopogon bradei Schltr.

Cyclopogon dusenii Schltr.

Cyclopogon dutraei Schltr.

Cyclopogon graciliscapa Schltr.

Cyclopogon hatschbachii Schltr.

Cyclopogon iguapensis Schltr.

Cyclopogon langei Schltr.

Cyclopogon multiflorus Schltr.

Cyclopogon paulensis Schltr.

Cyclopogon platyunguis Schltr.

Cyclopogon saxicolus Schltr.

Cyclopogon subalpestris Schltr.

Cyclopogon trifasciatus Schltr.

Cyrtopodium falcilobum Hoehne \& Schltr.

Cyrtopodium dusenii Schltr.

Cyrtopodium lissochiloides Hoehene \&Schltr.

Cyrtopodium paranaense Schltr.

Diacrium amazonicum Schltr.

Dichaea cogniauxiana Schltr.

Dipteranthus bradei Schltr.

Elleanthus pusillus Schltr.

Encyclia acuta Schltr.

Encyclia flabellifera Hoehne \& Schltr.

Encyclia huebneri Schltr.

Encyclia laxa Schltr.

Encyclia oxyphylla Schltr.

Encyclia tarumana Schltr.

Epidendrum alexandri Schltr.

Epidendrum amazonicum Schltr.

Epidendrum burgeri Schltr.

Epidendrum goebelii Schltr.

Epidendrum hatschbachii Schltr.

Epidendrum huebneri Schltr.

Epidendrum iguapensis Schltr.

Epidendrum kuhlmannii Schltr.

Epidendrum magelhaesi Schltr.

Epidendrum minarum Hoehne \& Schltr.

Epidendrum pedale Schltr.

Epidendrum pseudodifforme Hoehne \& Schltr.

Epidendrum regnellianum Hoehne \& Schltr.

Epidendrum versicolor Hoehne \& Schltr.

Fractiunguis brasiliensis Schltr.

Galeandra captoceras Schltr.

Galeandra huebneri Schltr.

Galeandra paranaensis Schltr.

Galeottia negrensis Schltr.

Habenaria achroantha Schltr.
Habenaria amazonica Schltr.

Habenaria bahiensis Schltr.

Habenaria belloi Schltr.

Habenaria bradei Schltr.

Habenaria butantanensis Hoehne \& Schltr.

Habenaria campos-portoi Schltr.

Habenaria christiani Schltr.

Habenaria crassipes Schltr.

Habenaria culmiformis Schltr.

Habenaria duckeana Schltr.

Habenaria dusenii Schltr.

Habenaria dutraei Schltr.

Habenaria edentula Schltr.

Habenaria flaccifolia Schltr.

Habenaria geehrtii Hoehne \& Schltr.

Habenaria georgii Schltr.

Habenaria heleogena Schltr.

Habenaria heterophylla Schltr.

Habenaria hoehnei Schltr.

Habenaria itatiayae Schltr.

Habenaria juergensii Schltr.

Habenaria kleyi Schltr.

Habenaria kuhlmannii Schltr.

Habenaria leaoana Schltr.

Habenaria luetzelburgii Schltr.

Habenaria marupaana Schltr.

Habenaria melanopoda Hoehne \& Schltr.

Habenaria minarum Hoehne \& Schltr.

Habenaria nana Schltr.

Habenaria ovatipetala Schltr.

Habenaria pilgeri Schltr.

Habenaria pleiophylla Hoehne \& Schltr. (Fig. 29)

Habenaria polygonoides Schltr.

Habenaria polyrhiza Schltr.

Habenaria rolfeana Schltr.

Habenaria sampaioana Schltr.

Habenaria sartoroides Schltr.

Habenaria sceptrum Schltr.

Habenaria schnittmeyeri Schltr.

Habenaria staminodiata Schltr.

Habenaria trimeropetala Schltr.

Habenaria verecunda Schltr.

Hexadesmia cearensis Schltr.

Isochilus brasiliensis Schltr.

Koellensteinia hyacinthoides Schltr.

Laelia bahiensis Schltr.

Laelia sincorana Schltr. 


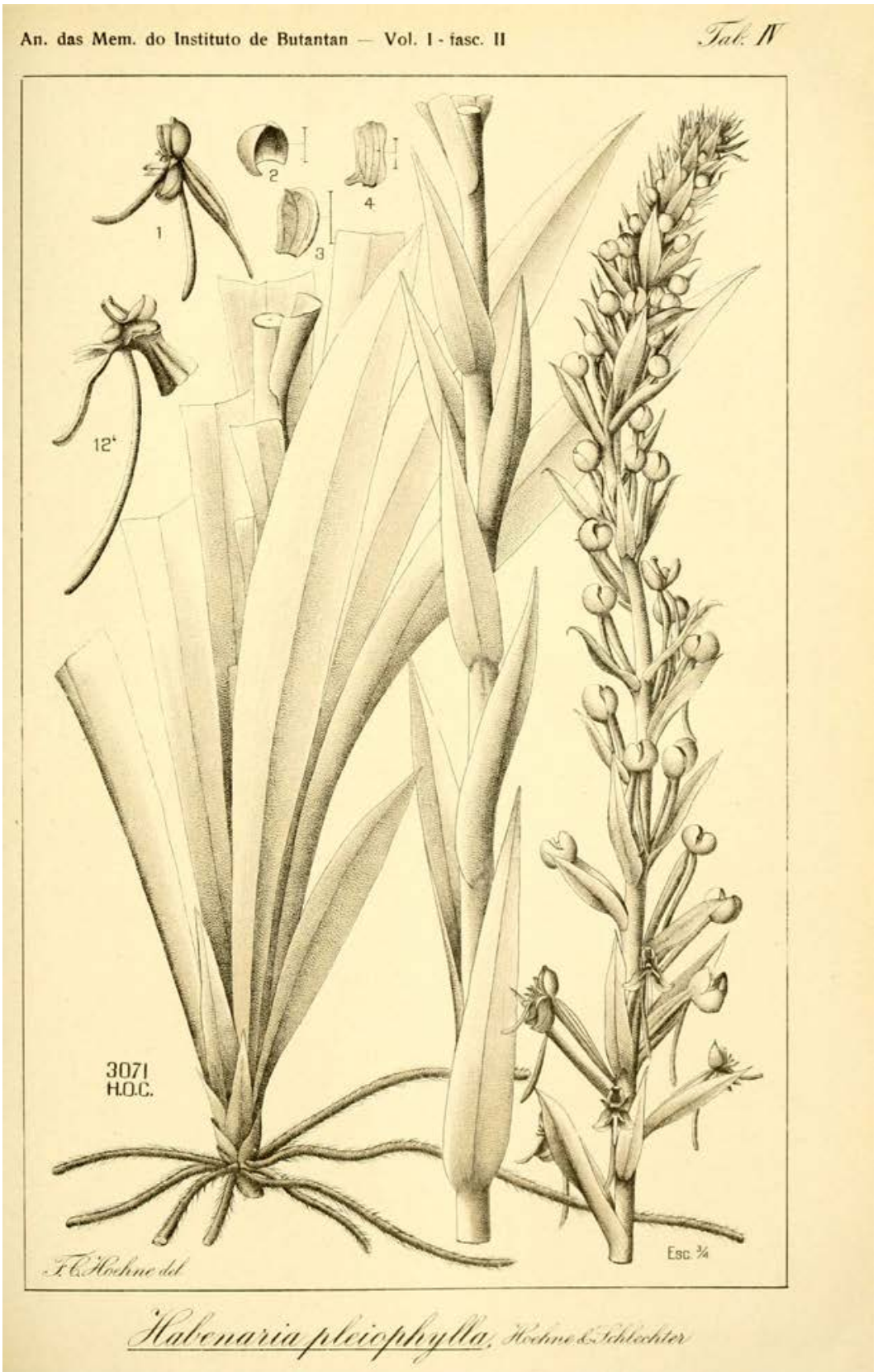

Figure 29. Habenaria pleiophylla Hoehne \& Schltr. In Anexos das Memorias do Instituto de Butantan, Seccao de Botanica, vol. I, fasc. II: table IV.

Masdevallia huebneri Schltr.

Masdevallia paranensis Schltr.

Maxillaria amazonica Schltr.

Maxillaria bradei Schltr. ex Hoehne

Maxillaria hatschbachii Schltr.
Maxillaria hedyosma Schltr.

Maxillaria hoehnei Schltr.

Maxillaria huebneri Schltr.

Maxillaria iguapensis Hoehne \& Schltr.

Maxillaria juergensii Schltr. 
Maxillaria lactea Schltr.

Maxillaria pachyphylla Schltr. ex Hoehne

Maxillaria petiolaris Schltr.

Maxillaria taracuana Schltr.

Microstylis muelleri Schltr.

Microstylis ovatilabia Schltr.

Microstylis pabstii Schltr.

Microstylis paranaensis Schltr.

Mormodes aurantiacum Schltr.

Neobartlettia kuhlmanii Schltr.

Notylia flexuosa Schltr.

Notylia longispicata Hoehne \& Schltr.

Notylia platyglossa Schltr.

Octomeria albiflora Hoehne \& Schltr.

Octomeria alexandri Schltr.

Octomeria brachypetala Schltr.

Octomeria bradei Schltr.

Octomeria campos-portoi Schltr.

Octomeria dusenii Schltr.

Octomeria elobata Schltr. ex Pabst

Octomeria fibrifera Schltr.

Octomeria gehrtii Hoehne \& Schltr.

Octomeria gracilicaulis Schltr.

Octomeria hatschbachii Schltr.

Octomeria hoehnei Schltr.

Octomeria iguapensis Schltr.

Octomeria irrorata Schltr.

Octomeria juergensii Schltr.

Octomeria lacerata Hoehne \& Schltr.

Octomeria rhodoglossa Schltr.

Octomeria riograndensis Schltr.

Octomeria serpens Schltr.

Octomeria similis Schltr.

Octomeria taracuana Schltr.

Octomeria umbonulata Schltr.

Octomeria unguiculata Schltr.

Oncidium aberrans Schltr.

Oncidium albinoi Schltr.

Oncidium beyrodtianum Schltr.

Oncidium blossfeldianum Schltr.

Oncidium cogniauxianum Schltr.

Oncidium hatschbachii Schltr.

Oncidium hoehnianum Schltr. ex Mansf.

Oncidium johnianum Schltr.

Oncidium mixtum Schltr.

Oncidium ottonis Schltr.

Oncidium patulum Schltr.
Oncidium psyche Schltr.

Oncidium reisii Hoehne \& Schltr.

Oncidium rhynchophorum Schltr. ex Hoehne

Oncidium zikanianum Hoehne \& Schltr.

Ornithocephalus brachystachyus Schltr.

Ornithocephalus myrtiphyllus Schlt. ex Hoehne

Paradisianthus neglectus Schltr.

Pelexia bradei Schltr. ex Mansf.

Pelexia burgeri Schltr.

Pelexia dolichorhiza Schltr.

Pelexia gracilis Schltr.

Pelexia incurvidens Schltr.

Pelexia itatiayae Schltr.

Pelexia laminata Schltr.

Pelexia luetzelburgii Schltr.

Pelexia mouraei Schltr.

Pelexia polyantha Schltr. ex Mansf.

Pelexia sceptrum Schltr.

Pelexia stictophylla Schltr.

Pelexia tenuior Schltr.

Phymatidium aquinoi Schltr.

Phymatidium herteri Schltr.

Physosiphon bradei Schltr.

Physurus bidentiferus Schltr.

Physurus foliosus Schltr. ex Porto \& Brade

Physurus longicalcaratus Schltr.

Physurus macer Hoehne \& Schltr.

Platyrhiza juergensii Schltr.

Pleurothallis albipetala Hoehne \& Schltr.

Pleurothallis alexandri Schltr.

Pleurothallis aquinoi Schltr.

Pleurothallis auriculigera Hoehne \& Schltr.

Pleurothallis barbosae Schltr.

Pleurothallis biglandulosa Schltr.

Pleurothallis bradei Schltr.

Pleurothallis butantanensis Hoehne \& Schltr.

Pleurothallis caldensis Hoehne \& Schltr.

Pleurothallis caroli Schltr.

Pleurothallis cearensis Schltr.

Pleurothallis ciliolata Schltr.

Pleurothallis corticicola Schltr. ex Hoehne

Pleurothallis curitybensis Schltr. ex Mans.

Pleurothallis curtii Schltr.

Pleurothallis dryadum Schltr.

Pleurothallis edwallii Dusen \& Schltr.

Pleurothallis gehrtii Hoehne \& Schltr.

Pleurothallis hatschbachii Schltr. 


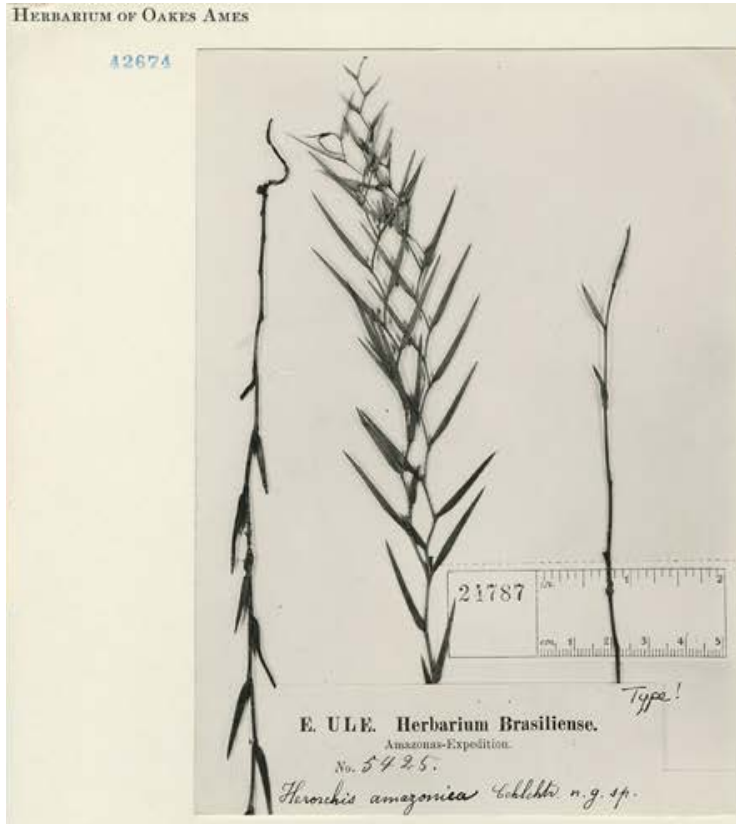

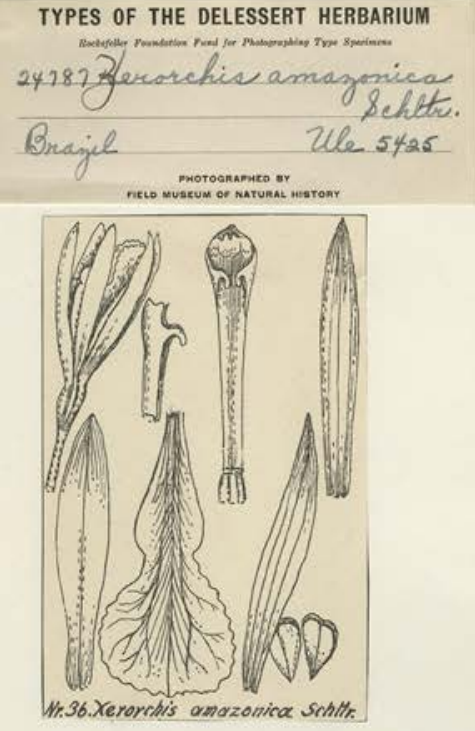

Ex Fedde Repert. Beihefte 58:

Schlechter, Blütenanalysen neuer Orehideen

I. Südamerikanische Orchideen
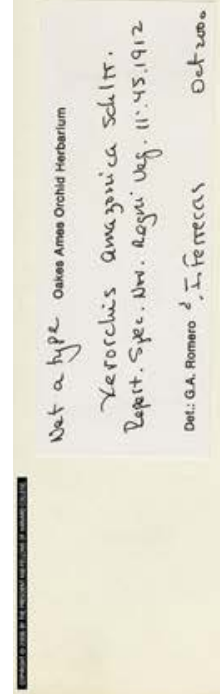

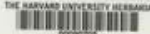

\begin{tabular}{c}
\hline MCROFICN BY MECRER \\
2933
\end{tabular}

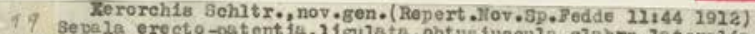
7 Bepala erecto -pat ent ia, 11 gula ta, obtuiluscula, glabra, ja teralia obliqua. Petala

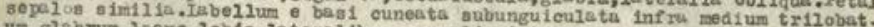
um glabrum, 2neve lobis lateralibus parvulis, intermedio mul to majore mirgini bus leviter undulatum. Column grac1lis, emiteres ap1cen versus peululo dilata. ta, juxta stigm brachila 2 fuleatis obtuala, decurvulis ornata, spoda rostelio. brevi, bidenta to. Anthera reniforn1 -cucul lata, obtusa, mbona ta, polilinis 8 , obilas que pyriformibus, 4 nis cohserent 1bus, Ovarium abelavatum, griciliter pediceli

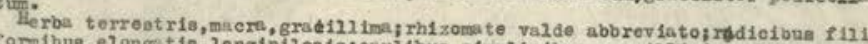

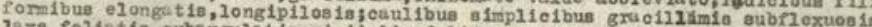

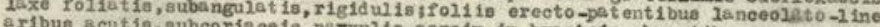

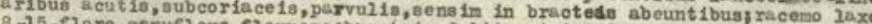

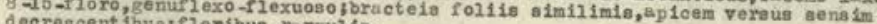
deoresent lous, fioribus purvuile.

Bpecies uns admo nots brisiliensis.

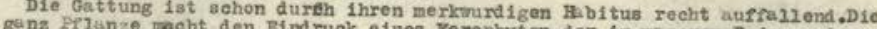
Vegetsing Kerophyten, dor 1 m mageren Boden seine dem 13 leantlua mo

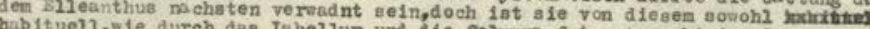
hur rur sileantion dackes sin Grunde der Iippe ist hier

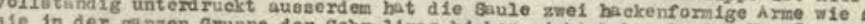
10 In der katazen drupe dor belkannt Bind.Von Bobrald platter le durch die columre minimien Dimenoionen und die nicht gefalteten

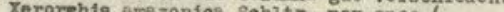

Xerorehis amaszonica Sehitr.,nov.spec.

bun 111 formibus

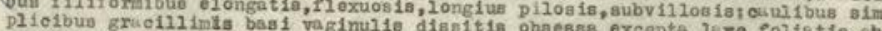
subflexuonie, fol11a erecto - patentibus, 1 n neolato textura subc riaceia, nervosis, $, 8-2,5 \mathrm{~cm}$ longis acutia vei aploulatia glabris

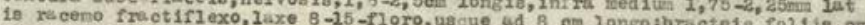
nino conform 1 bus, flores plus minueve excedent ibus, busifloribus psrvulis erecto -pstent thus oedent 1s vel aubs cut 1a, elabris, c.0.7

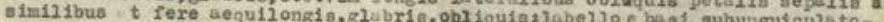

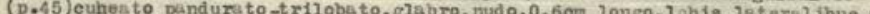
parrulia sbbreviatis, intermedio p.r. $75 \mathrm{~min}$ longs, ap icom veraus pe,

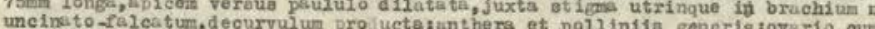
Ded1ce 120 e 2ongo.

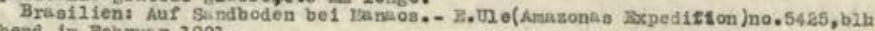
lie ine pebut 1907.

Linen obigen kusfuhrungen habe ich nichta mehr uber die prianse aususotzen lon wachte hier nur noch ervahnen disa ein Fe11 der Bluten un dem mir gutigst
\end{abstract}

FIgure 30. Xerorchis amazonica Schltr. Photograph of a specimen collected by E. Ule in Brazil, analytical drawing by R. Schlechter and Schlechter's original type-written manuscript of the description of the new species. Rockefeller Foundation. 
Pleurothallis hoehnei Schltr.

Pleurothallis huebneri Schltr.

Pleurothallis iguapensis Schltr.

Pleurothallis incurvidens Schltr.

Pleurothallis insularis Hoehne \& Schltr.

Pleurothallis ipyrangana Schltr.

Pleurothallis juergensii Schltr.

Pleurothallis lamproglossa Schltr.

Pleurothallis lepthantipoda Hoehne \& Schltr.

Pleurothallis leucorhoda Schltr.

Pleurothallis margaritifera Schltr.

Pleurothallis microblephara Schltr.

Pleurothallis microgemma Schltr. ex Hoehne

Pleurothallis microtis Schltr.

Pleurothallis mirabilis Schltr.

Pleurothallis pauloensis Hoehne \& Schltr.

Pleurothallis petersiana Schltr.

Pleurothallis rhabdosepala Schltr.

Pleurothallis sororcula Schltr.

Pleurothallis sparsiflora Schltr.

Pleurothallis stictophylla Schltr.

Pleurothallis subpicta Schltr.

Pleurothallis succedaneae Hoehne \& Schltr.

Pleurothallis taracuana Schltr.

Pleurothallis transparens Schltr.

Pleurothallis vellozoana Schltr.

Pleurothallis vinosa Hoehne \& Schltr.

Pogonia calantha Schltr.

Pogonia fragrans Schltr.

Pogonia humidicola Schltr.

Pogonia magnifica Schltr.

Pogonia paulensis Schltr.

Polystachya amazonica Schltr.

Polystachya bradei Schltr. ex Mansf.

Polystachya edwallii Hoehne \& Schltr.

Polystachya juergensii Schltr.

Polystachya huebneri Schltr.

Polystachya micrantha Schltr.

Polystachya stenophylla Schltr.

Promenaea acuminata Schltr.

Promenaea albescens Schltr.

Promenaea catharinensis Schltr.

Promenaea dusenii Schltr.

Promenaea fuerstenbergiana Schltr.

Promenaea malmquistiana Schltr.

Promenaea paranaensis Schltr.

Promenaea paulensis Schltr.
Promenaea polysphaera Schltr.

Promenaea riograndensis Schltr.

Promenaea stricta Schltr.

Promenaea truncicola Schltr.

Pseudostelis bradei Schltr.

Rodriguezia huebneri Schltr.

Rodriguezia minor Schltr.

Sarcoglottis albiflos Schltr. ex Hoehne

Sarcoglottis alexandri Schltr. ex Mansf.

Sarcoglottis glaucescens Schltr.

Sarcoglottis juergensii Schltr.

Sarcoglottis tenuis Schltr.

Scaphyglottis amazonica Schltr.

Scaphyglottis huebneri Schltr.

Scaphyglottis ochroleuca Schltr.

Sigmatostalix amazonica Schltr.

Spiranthes sincorensis Schltr.

Stanhopea minor Schltr.

Stelis aquinoana Schltr.

Stelis calotricha Schltr.

Stelis castanea Hoehne \& Schltr.

Stelis diaphana Schltr.

Stelis fragrans Schltr.

Stelis hoehnei Schltr.

Stelis huebneri Schltr.

Stelis inaequisepala Hoehne \& Schltr.

Stelis itatiayae Schltr.

Stelis juergensii Schltr.

Stelis macrochlamys Hoehne \& Schltr.

Stelis microphylla Hoehne \& Schltr.

Stelis paoloensis Hoehne \& Schltr.

Stelis porschiana Schltr.

Stelis peterostele Hoehne \& Schltr.

Stelis robusta Schltr.

Stelis schenckii Schltr.

Stelis thermophilla Schltr.

Stelis wettsteiniana Schltr.

Stenorrhynchos bradei Schltr.

Stenorrhynchos foliosus Schltr.

Trachelosiphon paranaense Schltr.

Triphora amazonica Schltr.

Triphora duckei Schltr.

Vanilla angustipetala Schltr.

Vanilla bradei Schltr. ex Mansf.

Xerorchis amazonica Schltr. (Fig. 30)

Zygostates aquinoi Schltr.

Zygostates paranaensis Schltr. 
The Guyanas (Fig. 28)

\section{Specific orchid tribes and subtribes, genera or species}

1910-1911 Schlechter, R. Orchidaceae novae et criticae, Decas XVI-XVII. Repertorium specierum novarum regni vegetabilis, Vol.10: 21-32.

1901 Schlechter, R. Orchidaceae. In Pilger, R. Beitrag zur Flora von Mattogrosso. Botanischer Bericht über die Expedition von Dr. Herrmann Meyer nach Central-Brasilien 1899. Botanische Jahrbücher für Systematik, Pflanzengeschichte und Pflanzengeographie 30: 149-150.

1914 Schlechter, R. Orchidaceae. In Pilger, R. Plantae Uleanae novae vel minus cognitae. Notizblatt des Königlichen Botanischen Gartens und Museums zu Berlin, Vol. 6: 120-126.

1917-1919 Schlechter, R. Orchidaceae novae et criticae, Decas $L X V$. Repertorium specierum novarum regni vegetabilis., Vol. 16: 353-358.

1918 Schlechter, R. Die Gattung Aganisia Ldl. und ihre Verwandten. Orchis, Monatsschrift der Deutschen Gesellschaft für Orchideenkunde, Vol. 12: 24-42.

1920 Schlechter, R. Versuch einer systematischen Neuordnung der Spiranthinae. Beihefte zum Botanischen Centralblatt. Zweite Abteilung, Systematik, Pflanzengeographie, angewandte Botanik 37(2): 317-454.

Schlechter, R. Beiträge zur Kenntnis der Orchidaceenflora von Paraná. Repertorium specierum Repertorium specierum novarum regni vegetabilis., Vol. 35: 1-108.

Schlechter's network in Guyana (orchid collectors, growers and other purveyors)

- Bartlett, Albert William (1875/76-1943), collected 1905-1906.

- Fiebrig, Karl August Gustav (1879-1951), collected 1902-1950.

- Hassler, Emil (1864-1937), collected 1895-1909, 1914, 1920-1937.

- Im Thurn, Everard Ferdinand (1852-1932), collected 1884-1906.

- Goebel, Karl Immanuel Eberhard Ritter von (1855-1932), collected 1890-1913.

- McConnell, Frederick Vavasour (1868-1914), collected 1891-1898.

- Ule, Ernst Heinrich Georg (1854-1915), collected 1893-1912.

\section{Orchids described by R. Schlechter from the Guyanas}

The following is a list of the orchids described by R. Schlechter as new to science from the Guyanas, as enumerated in the aforementioned bibliography (only basionyms):

\section{Neobartlettia Schltr.}

Epidendrum ulei Schltr.

Habenaria arecunarum Schltr.

Habenaria ernestii Schltr.

Koellensteinia roraimae Schltr.

\section{New orchid genera}

Otostylis Schtr.

\section{New orchid species}

\section{Maxillaria rugosa Schltr.}

Neobartlettia guianensis Schltr.

Pleurothallis stenocardium Schltr. (Fig. 31) 


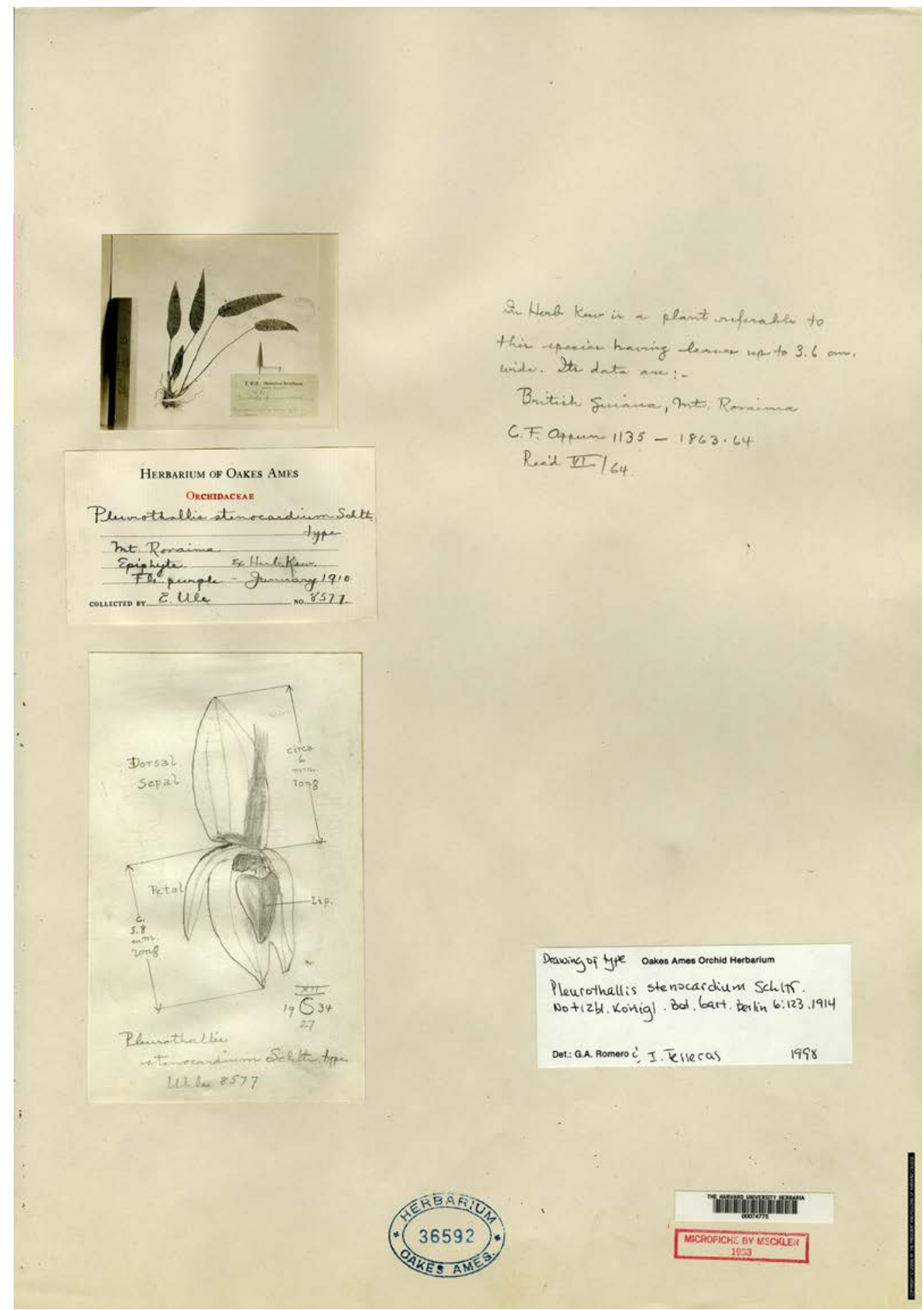

FIgure 31. Isotype of Pleurothallis stenocardium Schltr., collected by E. Ule in British Guyana with drawing of type by C. Schweinfurth (?). 


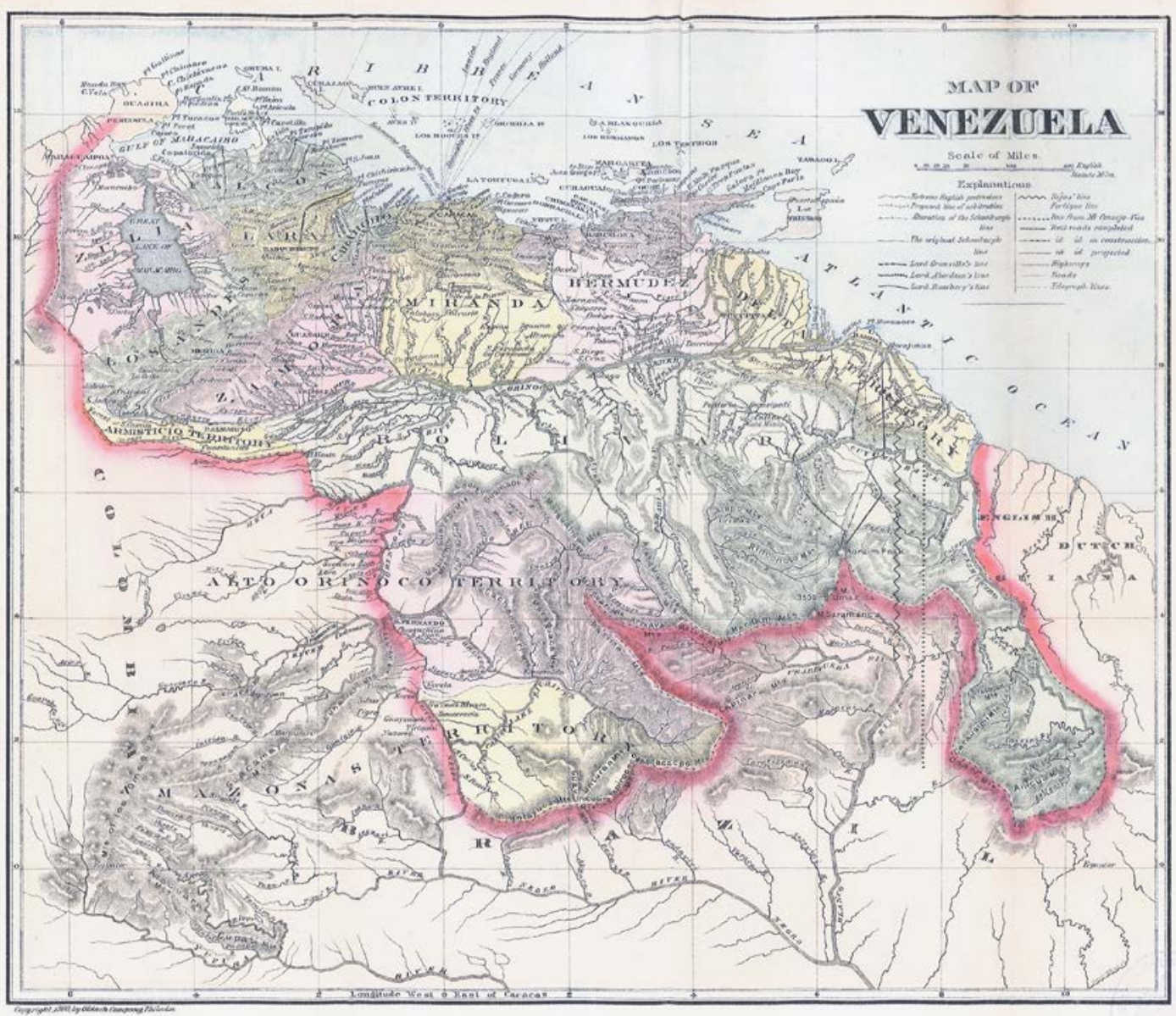

FIgURE 32. Map of Venezuela, 1900. Unknown author.

Venezuela (Fig. 32)

\section{National and regional orchid floras, specific collectors}

1919 Schlechter, R. Die Orchideenfloren der südamerikanischen Kordillerenstaaten. I. Venezuela. Repertorium specierum novarum regni vegetabilis, Beihefte, vol.6: 1-100.

\section{Specific orchid tribes and subtribes, genera or species}

1918-1919 Schlechter, R. Zwei interessante Gattungen der Spiranthinae. Repertorium specierum novarum regni vegetabilis, vol. 15: 416-417.

1920 Schlechter, R. Versuch einer systematischen Neuordnung der Spiranthinae. Beihefte zum Botanischen Centralblatt. Zweite Abteilung, Systematik, Pflanzengeographie, angewandte Botanik 37(2): 317-454.

Schlechter's network in Venezuela (orchid collectors, growers and other purveyors)

- Beyrodt, Otto (1879-1923), orchid grower in Marienfelde, Germany, around 1900-1923.

- Briceño Gabaldón, Salomón (1826-1912), collected from early 1870s on.

- GoeBel, Karl Immanuel Eberhard Ritter von (1855-1932), collected 1890-1913.

- Im ThuRn, Everard Ferdinand (1852-1932), German Caura Expedition, collected 1884-1906.

LANKESTERIANA 19(2). 2019. (C) Universidad de Costa Rica, 2019. 


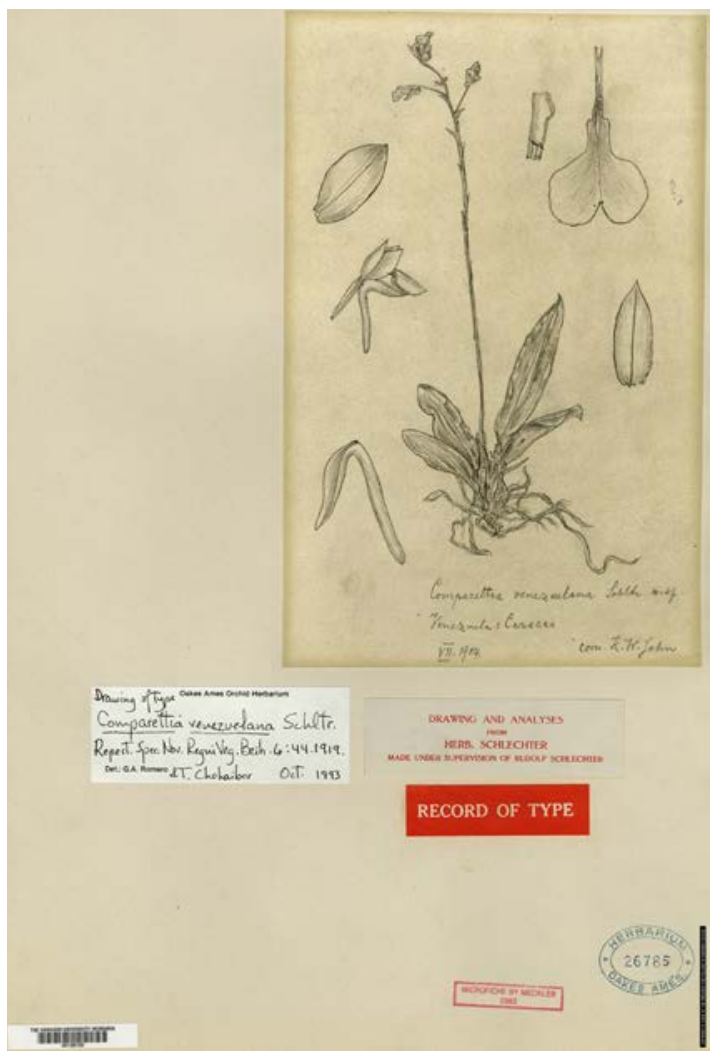

Figure 33. Drawing of type of Comparettia venezuelana Schltr., made under Schlechter's supervision. Nr. 26785 - Orchid Herbarium of Oakes Ames.

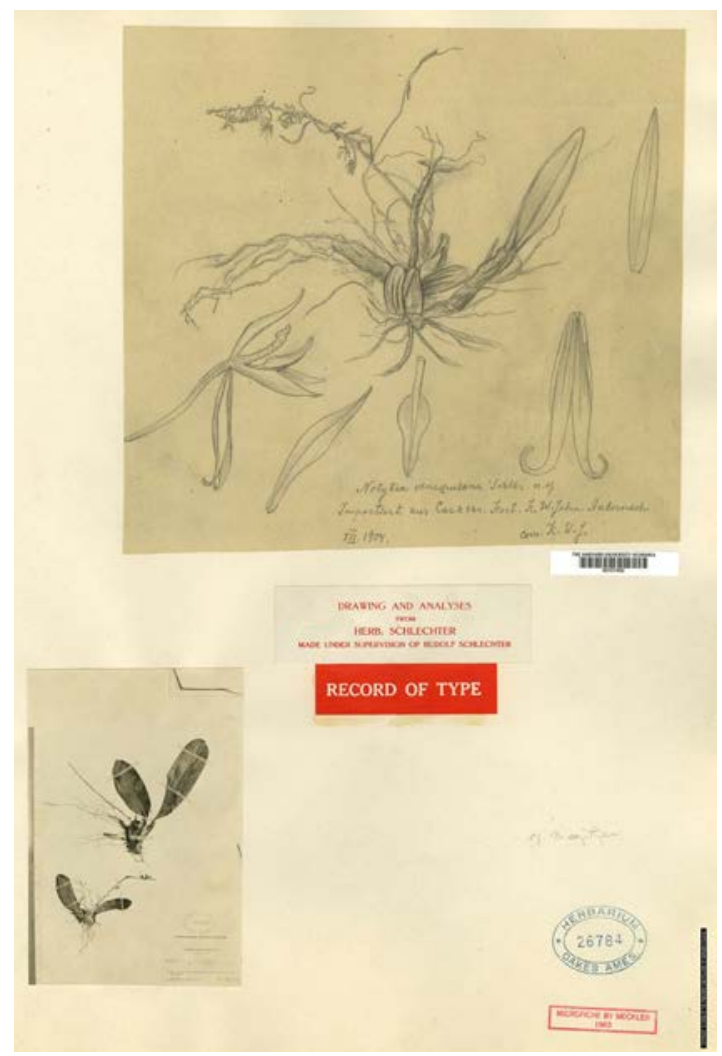

FIgURE 34. Specimen and drawing of type of Notylia venezuelana Schltr., made under Schlechter's supervision. Nr. 26784 - Orchid Herbarium of Oakes Ames.

- John, Karl Wilhelm (?), orchid grower in Andernach-on-the Rhine, Germany, around 1910.

- McConnell, Frederick Vavasour (1868-1914), collected 1891-1898.

- Passarge, Otto Karl Siegfried (1867-1958) and Selwyn, Jasper Henry (1819-1902), collected 1901-1902

- Pittier, Henri (1857-1950), collected ca. 1905-1950.

- Preuss, Paul Rudolf (1861-1926), collected 1899-1902.

- Ule, Ernst Heinrich Georg (1854-1915), collected 1893-1912.

- Wolter, Paul (1862-1942), orchid grower in Magdeburg-Wilhelmsburg.

Orchids described by R. Schlechter from Venezuela (Schlechter ex Knuoctomeriath in some cases)

The following is a list of the orchids described by R. Schlechter as new to science from Venezuela, as enumerated in the aforementioned bibliography (only basionyms):

Centrogenium Schltr.

\section{Bletia pittieri}

Bletia stenophylla Schltr.

Comparettia venezuelana Schltr. (Fig. 33)

\section{New orchid genera}

Discyphus Schltr.

\section{New orchid species}

Cranichis fendleri Schltr.

Cyrtopodium naiguatae Schltr.

Diacrium venezuelanum Schltr. 
Elleanthus galipanensis Schltr.

Encyclia leucantha Schltr.

Encyclia recurvata Schltr.

Epidendrum bathyschistum Schltr.

Epidendrum ernstii Schltr.

Epidendrum laetum Schltr.

Epidendrum pachyanthum Schltr.

Epidendrum tricallosum Schltr.

Epidendrum venezuelanum Schltr.

Gomphichis gracilis Schltr.

Govenia ernstii Schltr.

Habenaria caracasana Schltr.

Habenaria ernstii Schltr.

Habenaria gollmeri Schltr.

Hapalorchis cheirostyloides Schltr.
Liparis fendleri Schltr.

Microstylis johniana Schltr.

Notylia venezuelana Schltr. (Fig. 34)

Physurus pittieri Schltr.

Physurus venezuelanus Schltr. ex P. Knuth

Pleurothallis insconspicuiflora Schltr. ex P. Knuth

Pleurothallis intermedia Schltr.

Pleurothallis nephrocardia Schltr.

Pogonia nana Schltr.

Scaphosepalum trachypus Schltr.

Stelis amblyophila Schltr.

Stelis calceolus Schltr.

Stelis covilleana Schltr. ex Kunth

Stelis pittieri Schltr. ex Kunth

\section{Colombia (Fig. 35)}

\section{National and regional orchid floras, specific collectors}

1920 Schlechter, R. Die Orchideenfloren der südamerikanischen Kordillerenstaaten. II. Colombia. Repertorium specierum novarum regni vegetabilis, Beihefte, Vol.7: 1-301.

1924 Schlechter, R. Beiträge zur Orchideenkunde von Colombia. Repertorium specierum novarum regni vegetabilis, Beihefte, Vol. 27: 1-182.

\section{Specific orchid tribes and subtribes, genera or species}

1906 Schlechter, R. Über einige neue Orchidaceen. Orchis, Monatsschrift der Deutschen Gesellschaft für Orchideenkunde, Vol.1: 25 .

1910 Schlechter, R. Orchidaceae novae et criticae, Decas $X I V$-XV. Repertorium specierum novarum regni vegetabilis., Vol. 8, 1910: 561-572.

1911 Schlechter, R. Orchidaceae novae et criticae, Decas XVI-XVII. Repertorium specierum novarum regni vegetabilis, Vol.10: 21-32.

Schlechter, R. Neue und seltene Gartenorchideen. Orchis, Monatsschrift der Deutschen Gesellschaft für Orchideenkunde, Vol.5: 58-62.

1912 Schlechter, R. 1912. Neue und seltene Garten-Orchideen III, IV \& V. Orchis, Mitteilungen des Orchideenausschusses der Deutschen Gartenbau-Gesellschaft, vol. 6: 6-10, 63-69, 112-119.

1913 Schlechter, R. Orchidaceae novae et criticae, Decas XXXIX. Repertorium specierum novarum regni vegetabilis, Vol.12: 212-246.

1914 Schlechter, R. Die Orchideen ihre Beschreibung, Kultur und Züchtung Handbuch für Orchideenliebhaber, Kultivateure und Botaniker.

1915 Schlechter, R. Neue und seltene Garten-Orchideen, VIII. Orchis, Monatsschrift der Deutschen Gesellschaft für Orchideenkunde, vol. 9: 49-54.

Schlechter, R. Die Orchideen ihre Beschreibung, Kultur und Züchtung Handbuch für Orchideenliebhaber, Kultivateure und Botaniker. Verlagsnbuchhandlung Paul Parey, Berlin.

1916 Schlechter, R. Neue und seltene Garten-Orchideen, X. Orchis, Monatsschrift der Deutschen Gesellschaft für Orchideenkunde, vol. 10: 183-190.

1917 Schlechter, R. Die Gattung Acineta Ldl. Orchis, Monatsschrift der Deutschen Gesellschaft für Orchideenkunde, Vol. 11: $21-48$. 


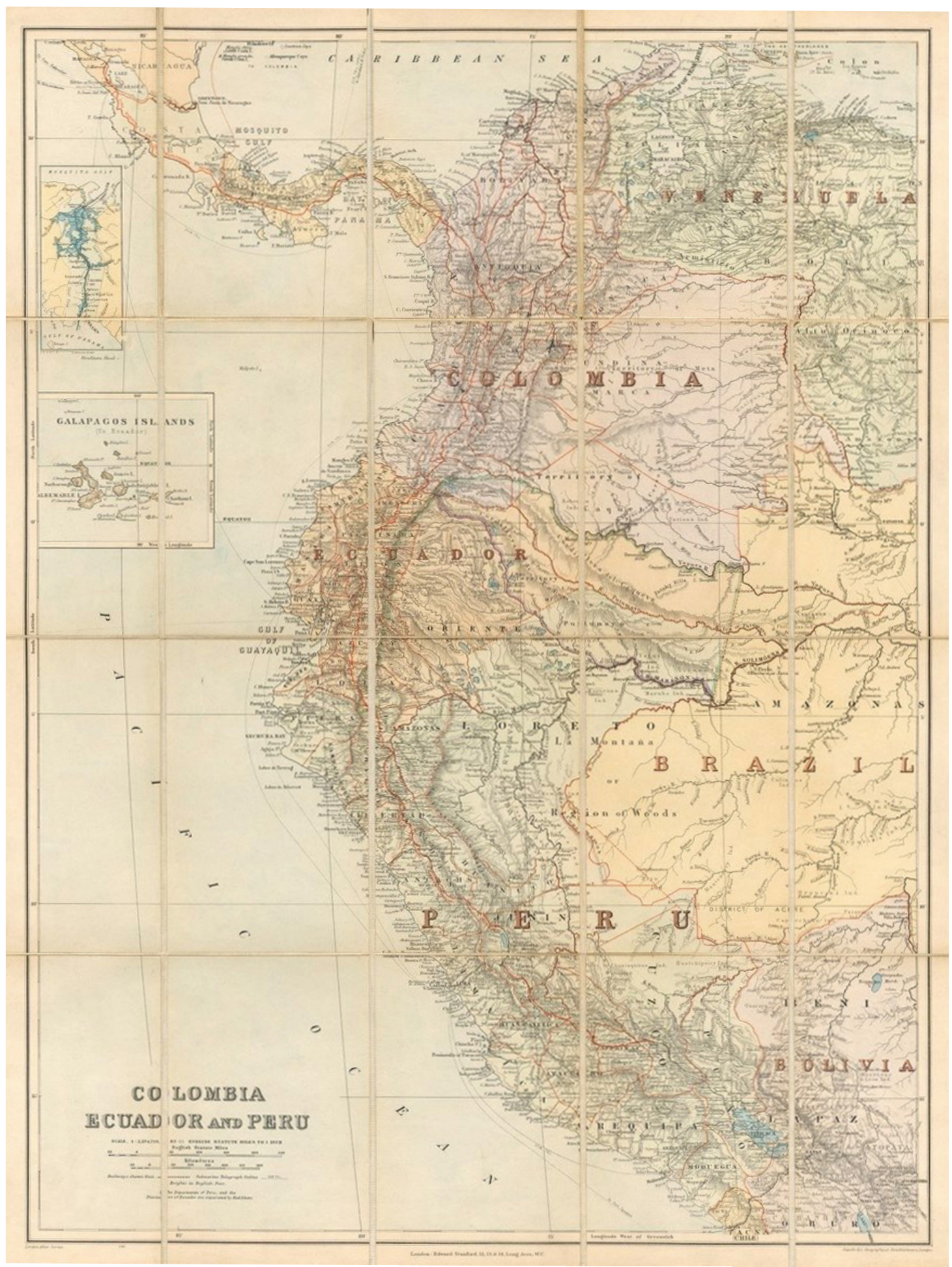

FIgURE 35. Map of Colombia, Ecuador and Peru. Edward Stanford, London, $192 ?$. 
1918 Schlechter. R. Orchidaceae novae, in caldariis Horti Dahlemensis cultae. Notizblatt des Botanischen Gartens und Museums zu Berlin-Dahlem, Vol.7 (66): 268-280.

1919 Schlechter. R. Orchidaceae novae, in caldariis Horti Dahlemensis cultae II. Notizblatt des Botanischen Gartens und Museums zu Berlin-Dahlem, vol.7: 323-330.

Schlechter, R. Die Gattung Cochlioda Ldl. Orchis, Monatsschrift der Deutschen Gesellschaft für Orchideenkunde, Vol. 13: 3-10.

1919-1920 Schlechter. R. Ueber einige neue Orchidaceen aus Colombia. Notizblatt des Botanischen Gartens und Museums zu Berlin-Dahlem, vol. 7: 527--532.

1920 Schlechter, R. Versuch einer systematischen Neuordnung der Spiranthinae. Beihefte zum Botanischen Centralblatt. Zweite Abteilung, Systematik, Pflanzengeographie, angewandte Botanik 37(2): 317-454.

1921-1924 Schlechter, R. Orchidaceae novae, in caldariis Horti Dahlemensis cultae III. Notizblatt des Botanischen Gartens und Museums zu Berlin - Dahlem, Vol. 8: 117-126.

1918 Schlechter. R. Orchidaceae novae, in caldariis Horti Dahlemensis cultae. Notizblatt des Botanischen Gartens und Museums zu Berlin-Dahlem, Vol.7 (66): 268-280.

1919 Schlechter. R. Orchidaceae novae, in caldariis Horti Dahlemensis cultae II. Notizblatt des Botanischen Gartens und Museums zu Berlin-Dahlem, vol.7: 323-330.

Schlechter, R. Die Gattung Cochlioda Ldl.. Orchis, Monatsschrift der Deutschen Gesellschaft für Orchideenkunde, Vol. 13: 3-10.

1919-1920 Schlechter. R. Ueber einige neue Orchidaceen aus Colombia. Notizblatt des Botanischen Gartens und Museums zu Berlin - Dahlem, vol. 7: 527-532.

1920 Schlechter, R. Versuch einer systematischen Neuordnung der Spiranthinae. Beihefte zum Botanischen Centralblatt. Zweite Abteilung, Systematik, Pflanzengeographie, angewandte Botanik 37(2): 317-454.

1921-1924 Schlechter, R. Orchidaceae novae, in caldariis Horti Dahlemensis cultae III. Notizblatt des Botanischen Gartens und Museums zu Berlin - Dahlem, Vol. 8: 117-126.

Schlechter's network in Colombia (orchid collectors, growers and other purveyors)

- Beyrodt, Otto (1879-1923), orchid grower in Marienfelde, Germany, around 1900-1923.

- Bungeroth, E. (?-1937), collected in Bucaramanga.

- Fürstenberg, Baron Max (Maximilian) von (1866-1925), owner of an orchid collection ca. 1900-1910.

- John, Karl Wilhelm (?), orchid grower in Andernach-on-the Rhine, Germany, around 1910.

- Hartmann (?), orchid grower in Lindenhaus, Niederhöchstadt, Taunus, Germany

- Hennis, Wilhelm (1856-1943), orchid grower in Hildesheim.

- Herrenhausen, Gardens of, Hannover.

- Hopf, H. (?), collected 1923.

- Hopp, Werner (1887-?), collected 1921 (with Santiago ArÉvalo).

- KaLBreyer, Wilhelm (1847-1912), collected 1877-1912.

- Langlassé, Eugène (1865-1900), collected 1898-1900.

- Lehmann, Friedrich Carl (1850-1903), collected 1867-1903.

- Madero, M. (?), collector in Antioquía and Cauca 1910.

- Pittier, Henri (1857-1950), collected ca. 1905-1950.

- Schmidtchen, Gustav (?), collected ca. 1923.

- Schnitter, R. (?), collected 1920-1921. 
- Schultze, Arnold (1875-1948), collected 1920-1927.

- Sмiтн, Herbert Huntington (1851-1919), collected 1891-1898.

- Sonntag, K. (?), collected 1888.

- StüBel, Moritz Alphons (1835-1904), collected 1868-1877.

- Wocke, Erich (1863-1941), collected 1889.

- Wolter, Paul (1862-1942), orchid grower in Magdeburg, ca. 1916.

\section{Orchids described by R. Schlechter from Colombia}

The following is a list of the orchids described by R. Schlechter as new to science from Colombia, as enumerated in the aforementioned bibliography (only basionyms):

\section{New orchid genera}

Antosiphon Schltr.

Caucaea Schltr.

Centrogenium Schltr.

Cirtoglottis Schltr.

Cyrtidium Schltr.

Monophyllorchis Schltr.

Aa colombiana Schltr.

Aa denticulata Schltr.

Aa maderoi Schltr.

Aa nigrescens Schltr.

Acineta antioquiae Schltr.

Acineta arcuata Schltr.

Acineta beyrodtiana Schltr.

Acineta gymnostele Schltr.

Acineta hennisiana Schltr.

Acineta wolteriana Schltr.

Anguloa goldschmidtiana Schltr.

Anguloa macroglossa Schltr.

Antosiphon roseans Schltr.

Barbosella dolichorhiza Schltr.

Barbosella longipes Schltr.

Bifrenaria pickiana Schltr.

Brachtia verruculifera Schltr.

Brachystele longiflora Schltr.

Brassia cyrtopetala Schltr.

Camaridium caquetanum Schltr.

Camaridium caucanum Schltr.

Camaridium equitans Schltr.

Camaridium lamprochlamys Schltr.

Camaridium quercicolum Schltr.

Camaridium sterrocaulon Schltr.
Porroglossum Schltr.

Roezliella Schltr.

Sphyrastylis Schltr.

Symphyglossum Schltr.

Warreella Schltr.

\section{New orchid species}

Campylocentrum colombianum Schltr. (Fig. 36)

Catasetum blepharochilum Schltr.

Catasetum caucanum Schltr.

Catasetum inornatum Schltr.

Catasetum platyglossum Schltr.

Chondrorhyncha amabilis Schltr.

Chrysocynis triptera Schltr.

Cranichis antioquensis Schltr.

Cranichis atrata Schltr.

Cranichis brachyblephara Schltr.

Cranichis cylindrostachys Schltr.

Cranichis ovatilabia Schltr.

Cranichis pastoensis Schltr.

Cranichis pleioneura Schltr.

Cranichis polyantha Schltr.

Cranichis polyblephara Schltr.

Cranichis pycnantha Schltr.

Cranichis styctophylla Schltr.

Comparettia erecta Schltr.

Comparettia pulchella Schltr.

Cryptocentrum flavum Schltr.

Cryptocentrum gracilipes Schltr.

Cryptocentrum hoppii Schltr.

Cryptocentrum pergracile Schltr.

Cyclopogon maderoi Schltr. 


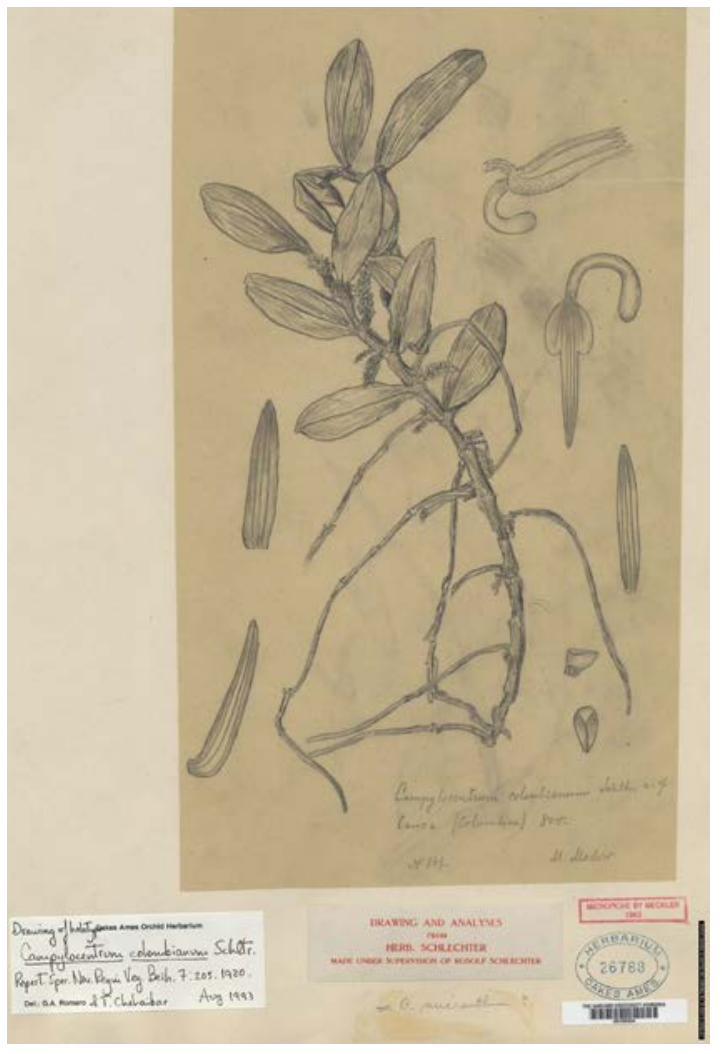

Figure 36. Campylocentrum colombianum Schltr. Drawing of type, made under Schlechter's supervision. $\mathrm{Nr}$. 26784 - Orchid Herbarium of Oakes Ames.

Cyclopogon spiranthoides Schltr.

Cycnoches brachydactylon Schltr.

Cyrtochilum rostratum Schltr.

Cyrtochilum simulans Schltr.

Cyrtoglottis gracilipes Schltr.

Dichaea acuminata Schltr.

Dichaea camaridioides Schltr.

Dichaea caquetana Schltr.

Dichaea lehmannii Schltr.

Dichaea selaginella Schltr.

Dichaea tenuifolia Schltr.

Dichaea trachysepala Schltr.

Dimerandra major Schltr.

Diothonea arevaloi Schltr.

Diothonea rhodochila Schltr.

Elleanthus ampliflorus Schltr.

Elleanthus bogotentis Schltr.

Elleanthus congestus Schltr.

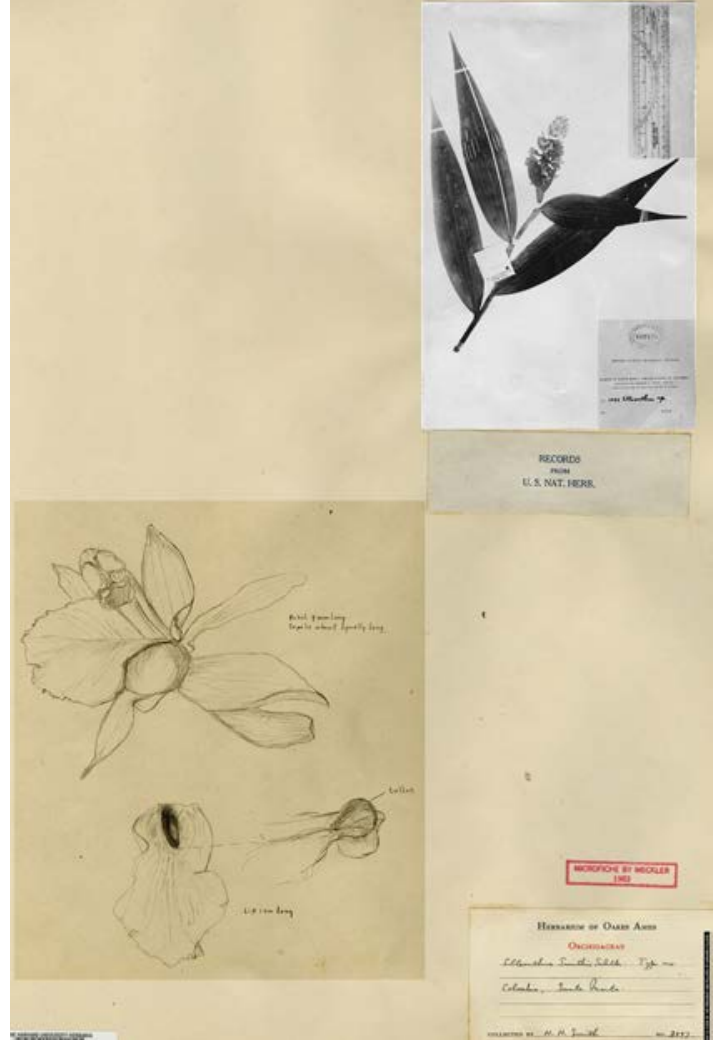

FiguRE 37. Photograph of type and analysis of flower of Elleanthus smithii Schltr. Oakes Ames Herbarium.

Elleanthus grandiflorus Schltr.

Elleanthus hoppii Schltr.

Elleanthus laetus Schltr.

Elleanthus leiocaulon Schltr.

Elleanthus pastoensis Schltr.

Elleanthus smithii Schltr. (Fig. 37)

Elleanthus sphaerocephalus Schltr.

Elleanthus venustus Schltr.

Elleanthus vinosus Schltr.

Encyclia maderoi Schltr.

Epidendrum anitae Schltr.

Epidendrum arnoldii Schltr.

Epidendrum antioquense Schltr.

Epidendrum atrobrunneum Schltr.

Epidendrum baumannianum Schltr.

Epidendrum bogotense Schltr.

Epidendrum brachyschistum Schltr.

Epidendrum bungerothii Schltr. 


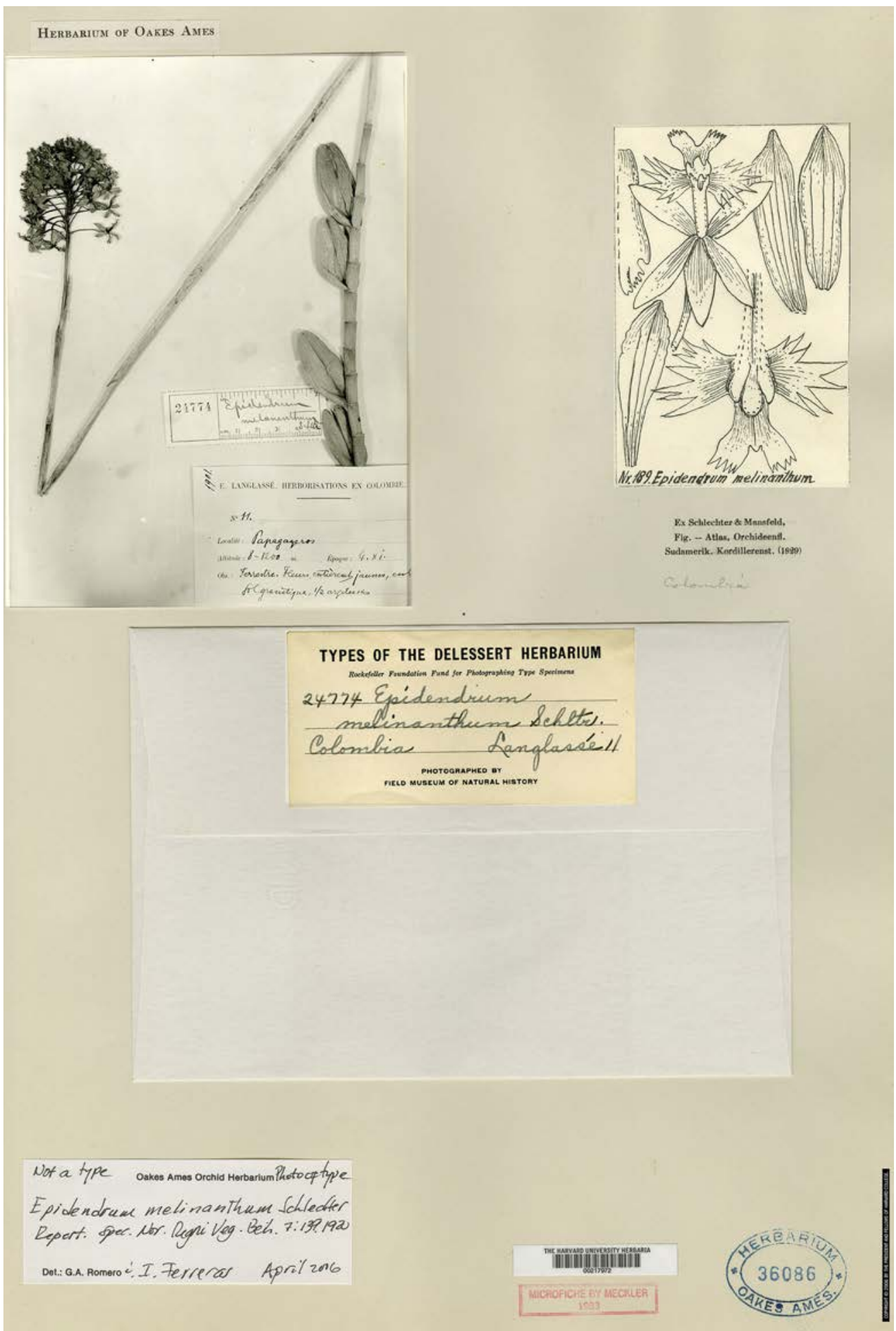

FIGURE 38. Epidendrum melinanthum Schltr. - Photograph of a specimen collected by E. Langlassé in Colombia and analytical drawing by R. Schlechter. Nr. 36086 - Oakes Ames Herbarium - Rockefeller Foundation 
Epidendrum calothyrsus Schltr.

Epidendrum caquetanum Schltr.

Epidendrum caucae Schltr.

Epidendrum cebolleta Schltr.

Epidendrum commelinoides Schltr.

Epidendrum cyclopterum Schltr.

Epidendrum decurviflorum Schltr.

Epidendrum diphyllum Schltr.

Epidendrum dolichopus Schltr.

Epidendrum elleanthoides Schltr.

Epidendrum euchroma Schltr.

Epidendrum eugenii Schltr.

Epidendrum fraternum Schltr.

Epidendrum hastilabium Schltr.

Epidendrum hopfianum Schltr.

Epidendrum ionodesme Schltr.

Epidendrum juncifolium Schltr.

Epidendrum laxifoliatum Schltr.

Epidendrum leucarachne Schltr.

Epidendrum longicrure Schltr.

Epidendrum macroceras Schltr.

Epidendrum maderoi Schltr.

Epidendrum melinanthum Schltr. (Fig. 38)

Epidendrum nubigerum Schltr.

Epidendrum oreogenum Schltr.

Epidendrum oxyglossum Schltr.

Epidendrum pachyneurum Schltr.

Epidendrum pachyphyllum Schltr.

Epidendrum pachypodum Schltr.

Epidendrum pastoense Schltr.

Epidendrum peraltum Schltr.

Epidendrum persimile Schltr.

Epidendrum polychistum Schltr.

Epidendrum prasinum Schltr.

Epidendrum protractum Schltr.

Epidendrum quinquecallosum Schltr.

Epidendrum rahbdobulbon Schltr.

Epidendrum rhopalobulbon Schltr.

Epidendrum rugulosum Schltr.

Epidendrum sanguineum Schltr.

Epidendrum sanctae martae Schltr.

Epidendrum schistochilum Schltr.

Epidendrum schnitteri Schltr.

Epidendrum scytocladium Schltr.

Epidendrum smithii Schltr.

Epidendrum sororium Schltr.

Epidendrum sterroanthum Schltr.
Epidendrum sterrophyllum Schltr.

Epidendrum strictum Schltr.

Epidendrum subfloribundum Schltr.

Epidendrum suborbiculare Schltr.

Epidendrum sympodiale Schltr.

Epidendrum trifidum Schltr.

Epidendrum trimeroglossum Schltr.

Epidendrum vulcanicum Schltr.

Epidendrum werneri Schltr.

Epidendrum zipaquinarum Schltr.

Eriopsis colombiana Schltr.

Galeandra leptoceras Schltr.

Gomphichis brachystachys Schltr.

Gomphichis caucana Schltr.

Gomphichis hetaerioides Schltr.

Gomphichis lancipetala Schltr.

Gomphichis scaposa Schltr.

Gongora beyrodtiana Schltr.

Gongora hennisiana Schltr.

Govenia platyglossa Schltr.

Govenia stictoglossa Schltr.

Habenaria caucana Schltr.

Habenaria maderoi Schltr.

Habenaria schultzei Schltr.

Habenaria smithii Schltr.

Hapalorchis longirostris Schltr.

Hapalorchis trilobata Schltr.

Hexisea colombiana Schltr.

Houlettia clarae Schltr.

Houlettia unguiculata Schltr.

Huntleya brevis Schltr.

Jacquiniella colombiana Schltr.

Kefersteinia tolimensis

Koellensteinia elegantula Schltr.

Laelia johniana Schltr.

Lanium colombianum Schltr.

Lepanthes antioquensis Schltr.

Lepanthes caucana Schltr.

Lepanthes dolichopus Schltr.

Lepanthes lehmanni Schltr.

Lepanthes marginata Schltr.

Lepanthes pastoensis Schltr.

Lepanthes peperomioides Schltr.

Lepanthes rhombipetala Schltr.

Lepanthes schnitteri Schltr.

Lepanthes stenoscleros Schltr.

Lepanthes superposita Schltr. 
Lepanthes trachysepala Schltr.

Lepanthes tricuspis Schltr.

Lindleyella floribunda Schltr.

Lindleyella picta Schltr.

Lindleyella saxicola Schltr.

Liparis caloglossa Schltr.

Liparis colombiana Schltr.

Lockhartia hologlossa Schltr.

Lockhartia unicornis Schltr.

Masdevallia bathychista Schltr.

Masdevallia callifera Schltr.

Masdevallia densiflora Schltr.

Masdevallia echinocarpa Schltr.

Masdevallia exilipes Schltr.

Masdevallia hoppii Schltr.

Masdevallia maculigera Schltr.

Masdevallia oligantha Schltr.

Masdevallia petiolaris Schltr.

Masdevallia pteroglossa Schltr.

Masdevallia tenuipes Schltr.

Masdevallia trichroma Schltr.

Maxillaria adscendens Schltr.

Maxillaria aequiloba Schltr.

Maxillaria angustifolia Schltr.

Maxillaria aurantiaca Schltr.

Maxillaria baumanniana Schltr.

Maxillaria bolleoides Schltr.

Maxillaria brachypoda Schltr.

Maxillaria camaridioides Schltr.

Maxillaria caquetana Schltr.

Maxillaria caucana Schltr.

Maxillaria caulina Schltr.

Maxillaria elata Schltr.

Maxillaria elegans Schltr.

Maxillaria farinifera Schltr.

Maxillaria hennisiana Schltr.

Maxillaria hoppii Schltr.

Maxillaria langlassei Schltr.

Maxillaria maderoi Schltr.

Maxillaria microblephara Schltr.

Maxillaria modesta Schltr.

Maxillaria ochroglossa Schltr.

Maxillaria parvula Schltr.

Maxillaria patens Schltr.

Maxillaria phaeoglossa Schltr.

Maxillaria pleiantha Schltr.

Maxillaria plicata Schltr.
Maxillaria saxicola Schltr.

Maxillaria schnitteri Schltr.

Maxillaria schultzei Schltr.

Maxillaria sulfurea Schltr.

Maxillaria subpandurata Schltr.

Maxillaria subulifolia Schltr.

Maxillaria tristis Schltr.

Maxillaria truncatilabia Schltr.

Maxillaria unguiculata Schltr.

Maxillaria unguilabia Schltr.

Maxillaria verecunda Schltr.

Maxillaria vestita Schltr.

Maxillaria witsenioides Schltr.

Microstylis hopii Schltr.

Microstylis mucronulata Schltr.

Microstylis polyblephara Schltr.

Monophyllorchis colombiana Schltr.

Mormodes schultzei Schltr.

Notylia oberonia Schltr.

Notylia obtusa Schltr.

Notylia rimbachii Schltr.

Octomeria colombiana Schltr.

Octomeria longerepens Schltr.

Octomeria longifolia Schltr.

Octomeria mocoana Schltr.

Odontoglossum bogotense Schltr.

Odontoglossum crispum Schltr.

Odontoglossum cristatellum Schltr.

Odontoglossum floribundum Schltr.

Odontoglossum hoppii Schltr.

Odontoglossum maderoi Schltr.

Odontoglossum schultzei Schltr.

Oncidium bryoclaudium Schltr.

Oncidium caucanum Schltr.

Oncidium hedyosmum Schltr.

Oncidium hoppii Schltr.

Oncidium maderoi Schltr.

Oncidium oberonia Schltr.

Oncidium platychilum Schltr.

Oncidium trachycaulon Schltr.

Oncidium saxicolum Schltr.

Oncidium werneri Schltr.

Ornithidium compactum Schltr.

Ornithidium cyperifolium Schltr.

Ornithidium dichotomum Schltr.

Ornithidium pastoense Schltr.

Ornithidium rhodoleucon Schltr. 
Ornithidium toriferum Schltr.

Ornithidium vagans Schltr.

Ornithidium virescens Schltr.

Ornithocephalus lehmannii Schltr.

Ornithocephalus micranthus Schltr.

Pachyphyllum bryophytum Schltr.

Pachyphyllum micrangis Schltr.

Pachyphyllum micranthum Schltr.

Pachyphyllum stuebellii Schltr.

Pachyphyllum vaginatum Schltr.

Pelexia cancae Schltr.

Pelexia hamata Schltr.

Physurus caucanus Schltr.

Physurus dolichostachys Schltr.

Physurus erythrodoides Schltr.

Physurus hetaerioides Schltr.

Physurus palaceus Schltr.

Physurus procerus Schltr.

Physurus zeuxinoides Schltr.

Pitiphyllum amesianum Schltr.

Pitiphyllum antioquense Schltr.

Platystele schmidtchenii Schltr.

Pleurothallis arevaloi Schltr.

Pleurothallis belocardia Schltr.

Pleurothallis bogotentis Schltr.

Pleurothallis brachyantha Schltr.

Pleurothallis brevicaulis Schltr.

Pleurothallis caliensis Schltr.

Pleurothallis chachatoynsis Schltr.

Pleurothallis chlamydopus Schltr.

Pleurothallis citrina Schltr.

Pleurothallis cundinamarcae Schltr.

Pleurothallis cymbisepala Schltr.

Pleurothallis falcipetala Schltr.

Pleurothallis hirtipes Schltr.

Pleurothallis hopfiana Schltr.

Pleurothallis hoppii Schltr.

Pleurothallis ineziae Schltr.

Pleurothallis lancifera Schltr.

Pleurothallis langlassei Schltr.

Pleurothallis auta Schltr.

Pleurothallis lehmanniana Schltr.

Pleurothallis leontoglossa Schltr.

Pleurothallis lepanthoides Schltr.

Pleurothallis leptantha Schltr.

Pleurothallis medellinensis Schltr.

Pleurothallis melittantha Schltr.
Pleurothallis microptera Schltr.

Pleurothallis mocoana Schltr.

Pleurothallis nasuta Schltr.

Pleurothallis nubigena Schltr.

Pleurothallis nutans Schltr.

Pleurothallis ochroleuca Schltr.

Pleurothallis papillisepala Schltr.

Pleurothallis patula Schltr.

Pleurothallis pendula Schltr.

Pleurothallis peniculus Schltr.

Pleurothallis phaeantha Schltr.

Pleurothallis platycardium Schltr.

Pleurothallis platysepala Schltr.

Pleurothallis pleiostachys Schltr.

Pleurothallis potamophila Schltr.

Pleurothallis pteroglossa Schltr.

Pleurothallis pulvinipes Schltr.

Pleurothallis quadricaudata Schltr.

Pleurothallis rhaphidopus Schltr.

Pleurothallis scaphioglottis Schltr.

Pleurothallis schistopetala Schltr.

Pleurothallis schnitteri Schltr.

Pleurothallis serricardia Schltr.

Pleurothallis smithii Schltr.

Pleurothallis sororia Schltr.

Pleurothallis sotarae Schltr.

Pleurothallis spathilabia Schltr.

Pleurothallis stelidioides Schltr.

Pleurothallis trianae Schltr.

Pleurothallis werneri Schltr.

Pogonia acuminata Schltr.

Pogonia elegantula Schltr.

Pogonia maderoi Schltr.

Pogonia venusta Schltr.

Polycycnis acutiloba Schltr.

Polystachya caquetana Schltr.

Polystachya colombiana Schltr.

Ponthieva elata Schltr.

Ponthieva microglossa Schltr.

Ponthieva triloba Schltr.

Porroglossum colombianum Schltr.

Prescottia filiformis Schltr.

Prescottia gracilis Schltr.

Prescottia longifolia Schltr.

Prescottia smithii Schltr.

Pseudocentrum sphaerocorys Schltr.

Pterichis acuminata Schltr. 
Pterichis tomentosula Schltr.

Restrepia antioquensis Schltr.

Restrepia caucana Schltr.

Restrepia hemsleyana Schltr.

Restrepia leontoglossa Schltr.

Restrepia serrilabia Schltr.

Rodriguezia arevaloi Schltr.

Rodriguezia macrantha Schltr.

Rodriguezia secunda Schltr.

Roezliella cucullifera Schltr.

Roezliella ibis Schltr.

Scaphosepalum platypetalum Schltr.

Scaphyglottis exilis Schltr.

Scaphyglottis genychila Schltr.

Scaphyglottis sanctae-martae Schltr.

Scaphyglottis stricta Schltr.

Scelochilus langlassei Schltr.

Schlimia pandurata Schltr.

Schomburgkia elata Schltr.

Schomburgkia schultzei Schltr.

Schomburgkia splendida Schltr.

Sertifera colombiana Schltr.

Sertifera major Schltr.

Sertifera parviflora Schltr.

Sigmatostalix caquetana Schltr.

Sigmatostalix pandurata Schltr.

Sobralia anceps Schltr.

Sobralia antioquensis Schltr.

Sobralia densifoliata Schltr.

Sobralia exilis Schltr.

Sobralia hoppii Schltr.

Sobralia kalbreyeri Schltr.

Sobralia malmquistiana Schltr.

Sobralia odorata Schltr.

Sobralia schultzei Schltr.

Sobralia splendida Schltr.

Sphyrastylis hoppii Schltr.

Sphyrastylis oberonioides Schltr.

Stanhopea hoppii Schltr.

Stelis antioquensis Schltr.

Stelis apiculata Schltr.

Stelis arevaloi Schltr.

Stelis bigibba Schltr.

Stelis bogotentis Schltr.

Stelis bracteata Schltr.

Stelis caucae Schltr.

Stelis citrina Schltr.
Stelis crassilabia Schltr.

Stelis cuculligera Schltr.

Stelis cundinamarcae Schltr.

Stelis cycloglossa Schltr.

Stelis decipiens Schltr.

Stelis dolichopus Schltr.

Stelis elegantula Schltr.

Stelis eugenii Schltr.

Stelis exilipes Schltr.

Stelis fruticulus Schltr.

Stelis hennisiana Schltr.

Stelis hoppi Schltr.

Stelis langlassei Schltr.

Stelis longiracemosa Schltr.

Stelis macropoda Schltr.

Stelis maderoi Schltr.

Stelis magnipetala Schltr.

Stelis mesohybos Schltr.

Stelis minimiflora Schltr.

Stelis mirabilis Schltr.

Stelis mocoana Schltr.

Stelis mисronipetala Schltr.

Stelis myriantha Schltr.

Stelis oligoblephara Schltr.

Stelis oxypetala Schltr.

Stelis pachyphilla Schltr.

Stelis pachystele Schltr.

Stelis pastoensis Schltr.

Stelis petiolaris Schltr.

Stelis pleistantha Schltr.

Stelis prorepens Schltr.

Stelis ringens Schltr.

Stelis scandens Schltr.

Stelis schmidtchenii Schltr.

Stelis schnitteri Schltr.

Stelis simula Schltr.

Stelis tenuis Schltr.

Stelis tolimensis Schltr.

Stelis trianaei Schltr.

Stelis umbriae Schltr.

Stelis verecunda Schltr.

Stelis virgulata Schltr.

Stelis vulcanica Schltr.

Stelis walteri Schltr.

Stelis werneri Schltr.

Telipogon caucanus Schltr.

Telipogon cycloglossus Schltr. 
Telipogon gracilis Schltr.

Telipogon hoppii Schltr.

Telipogon lagunae Schltr.

Telipogon pastoanus Schltr.

Telipogon venustus Schltr.

Trachelosiphon colombianus Schltr.

Trachelosiphon cristatus Schltr.
Trichocentrum brachyceras Schltr.

Trichocentrum verruciferum Schltr.

Vanilla calyculata Schltr.

Warreella cyanea Schltr.

Xylobium modestum Schltr.

Xylobium stanhopeifolium Schltr.

ECUAdor (Fig. 35)

\section{National and regional orchid floras, specific collectors}

1914-1916 Schlechter, R. Orchidaceae novae et criticae, Decas XLII-XLVI. Additamenta ad Orchideologiam ecuadorensem I. Repertorium specierum novarum regni vegetabilis, Vol. 14: 114-133.

Schlechter, R. Orchidaceae novae et criticae, Decas XLVII-XLVIII. Additamenta ad Orchideologiam ecuadorensem II. Repertorium specierum novarum regni vegetabilis, Vol. 14: 385-395.

1917-1919 Schlechter, R.. Orchidaceae novae et criticae, Decas XLIX. Additamenta ad Orchideologiam ecuadorensem III. Repertorium specierum novarum regni vegetabilis, Vol. 15: 49-59.

1921 Schlechter, R. Die Orchideenfloren der südamerikanischen Kordillerenstaaten. III. Ecuador. Repertorium specierum novarum regni vegetabilis, Beihefte, vol. 8: 1-172.

\section{Specific orchid tribes and subtribes, genera or species}

1910-1911 Schlechter, R. Orchidaceae novae et criticae, Decas XI, XII, XIII, XIV, XV. Repertorium specierum novarum regni vegetabilis, Vol.8: 453-58, 500-512, 561-574.

Schlechter, R. Orchidaceae novae et criticae, Decas XVI-XVII. Repertorium specierum novarum regni vegetabilis, Vol. 10: 21-32.

1911-1912 Schlechter, R. Orchidaceae novae et criticae, Decas XVI-XVII. Repertorium specierum novarum regni vegetabilis, Vol. 10: 21-32.

Schlechter, R. Orchidaceae novae et criticae, Decas XXVI. Repertorium specierum novarum regni vegetabilis, Vol. 10: 291-296.

1915 Schlechter, R. Orchidaceae novae et criticae, Decas XLII-XLVI. Repertorium specierum novarum regni vegetabilis, Vol. 14: 114-131.

1919 Schlechter, R. Die Gattung Cochlioda Ldl.. Orchis, Monatsschrift der Deutschen Gesellschaft für Orchideenkunde, Vol. 13: 3-10.

Schlechter's network in Ecuador (orchid collectors, growers and other purveyors)

- EgGERs, Henrik Franz Alexander von (1844-1903), collected 1891-1897.

- Hennis, Wilhelm ((1856-1943)), orchid grower in Hildesheim.

- Lehmann, Friedrich Carl (1850-1903), collected 1867-1903.

- Mille, Louis (Aloysius) (?-1940s), collected ca. 1896-1963.

- Rimbach, August (1862-1943), collected 1891-1934.

- Sodiro, Luigi Aloysius (Luis) (1836-1909), collected 1876-1907.

\section{Orchids described by R. Schlechter from Ecuador}

The following is a list of the orchids described by R. Schlechter as new to science from Ecuador, as enumerated in the aforementioned bibliography (only basionyms): 


\section{New orchid genera}

Dipterostele Schltr.

Sodiroella Schltr.

Aa macra Schltr.

Aa rhynchocarpa Schltr.

Aa riobambae Schltr.

Aa ustulata Schltr.

Bletia ecuadorensis Schltr.

Camaridium dichotomum Schltr.

Camaridium longum Schltr.

Camaridium sodiroi Schltr.

Campylocentrum ecuadorense Schltr.

Campylocentrum rimbachii Schltr.

Catasetum sodiroi Schltr.

Cranichis cucullata Schltr.

Cranichis ecuadorensis Schltr.

Cranichis elliptica Schltr.

Cranichis sororia Schltr.

Cryptarrhena unguicalata Schltr.

Cryptophoranthus beloglottis Schltr.

Cyclopogon argyrotaenius Schltr.

Cyclopogon cranichioides Schltr.

Cyclopogon gracilis Schltr.

Cyclopogon macer Schltr.

Dichaea ecuadorensis Schltr.

Dichaea sodiroi Schltr.

Diothonea angustifolia Schltr.

Diothonea pulchra Schltr.

Diothonea sodiroi Schltr.

Diothonea viridiflora Schltr.

Dipterostele microglossa Schltr.

Elleanthus fractiflexus Schltr.

Elleanthus macer Schltr.

Elleanthus petrogeiton Schltr.

Elleanthus roseus Schltr.

Elleanthus sodiroi Schltr.

Elleanthus stenophyllus Schltr.

Elleanthus ventricosus Schltr.

Encyclia angustiloba Schltr.

Encyclia trachypus Schltr.

Epidendrum aloisii Schltr.

Epidendrum atacazoicum Schltr.

Epidendrum bifalce Schltr.

Epidendrum brachystele Schltr.

Epidendrum caloglossum Schltr.
Solenocentrum Schltr.

Symphyglossum Schltr.

\section{New orchid species}

Epidendrum calyptrochilum Schltr.

Epidendrum chimborazoensis Schltr.

Epidendrum chortophyllum Schltr.

Epidendrum cuencanum Schltr.

Epidendrum cuniculatum Schltr.

Epidendrum dasytaenium Schltr.

Epidendrum diothonaeoides Schltr.

Epidendrum fruticetorum Schltr.

Epidendrum geminatum Schltr.

Epidendrum guayasense Schltr.

Epidendrum imitans Schltr.

Epidendrum indecoratum Schltr.

Epidendrum inornatum Schltr.

Epidendrum megahybos Schltr.

Epidendrum microglossum Schltr.

Epidendrum millei Schltr.

Epidendrum miniatum Schltr.

Epidendrum mojandae Schltr.

Epidendrum monanthum Schltr.

Epidendrum neglectum Schltr.

Epidendrum neolehmannia Schltr.

Epidendrum ochranthum Schltr.

Epidendrum ornithidii Schltr.

Epidendrum ornithoglossum Schltr.

Epidendrum orthocaule Schltr.

Epidendrum pallatangae Schltr.

Epidendrum pedicellare Schltr.

Epidendrum peperomioides Schltr.

Epidendrum pergracile Schltr.

Epidendrum pichinchae Schltr.

Epidendrum piestopus Schltr.

Epidendrum platychilum Schltr.

Epidendrum podocarpophilum Schltr.

Epidendrum pteroglottis Schltr.

Epidendrum quisayanum Schltr.

Epidendrum ramistratum Schltr.

Epidendrum reichenbachianum Schltr.

Epidendrum renilabium Schltr.

Epidendrum rhacoglossum Schltr. Schltr.

Epidendrum rimbachii Schltr.

Epidendrum riobambae Schltr.

Epidendrum sarcoglottis Schltr. 
Epidendrum sodiroi Schltr.

Epidendrum spathatum Schltr.

Epidendrum sphaeranthum Schltr.

Epidendrum splendidum Schltr.

Epidendrum rachychlaena Schltr.

Epidendrum tunguraguae Schltr.

Epidendrum zingiberaceum Schltr.

Epistephium lamprochyllum Schltr.

Gomphichis cranichioides Schltr.

Gomphichis sodiroi Schltr.

Govenia sodiroi Schltr.

Habenaria millei Schltr.

Habenaria sodiroi Schltr.

Kefersteinia lojae Schltr.

Lanium ecuadorense Schltr.

Lepanthes aberrans Schltr.

Lepanthes corazonis Schltr.

Lepanthes effusa Schltr.

Lepanthes elegantula Schltr.

Lepanthes macropoda Schltr.

Lepanthes macroura Schltr.

Lepanthes millei Schltr.

Lepanthes pensilis Schltr.

Lepanthes rhodophylla Schltr.

Liparis commelinoides Schltr.

Liparis millei Schltr.

Liparis nigrescens Schltr.

Masdevallia corazonica Schltr.

Masdevallia parvula Schltr.

Masdevallia sodiroi Schltr.

Masdevallia ventricosa Schltr.

Maxillaria ecuadorensis Schltr.

Maxillaria microdendron Schltr.

Maxillaria microtricha Schltr.

Maxillaria nutantiflora Schltr.

Maxillaria poicilothece Schltr.

Maxillaria sanguineomaculata Schltr.

Maxillaria stictantha Schltr.

Maxillaria stricta Schltr.

Maxillaria xantholeuca Schltr.

Microstylis lloensis Schltr.

Microstylis pichinchae Schltr.

Microstylis sodiroi Schltr.

Nasonia robusta Schltr.

Notylia ecuadorensis Schltr.

Notyliarimbachii Schltr.

Odontoglossum sodiroi Schltr.
Oncidium aloisii Schltr.

Oncidium hapalotyle Schltr.

Oncidium millei Schltr.

Oncidium sodiroi Schltr.

Ornithidium breve Schltr.

Ornithidium chrysocynoides Schltr.

Ornithidium pleurothantioides Schltr.

Ornithidium squarrosum Schltr.

Ornithocephalus bryostachyus Schltr.

Pelexia ecuadorensis Schltr.

Physosiphon inaequisepalus Schltr.

Pleurothallis aloisii Schltr.

Pleurothallis blepharopetala Schltr.

Pleurothallis cardiophylla Schltr.

Pleurothallis conchopetala Schltr.

Pleurothallis corazonica Schltr.

Pleurothallis diploglossa Schltr.

Pleurothallis ecuadorensis Schltr.

Pleurothallis fimbripetala Schltr.

Pleurothallis henrici Schltr.

Pleurothallis ignivomi Schltr.

Pleurothallis lamprochlamys Schltr.

Pleurothallis lasioglossa Schltr.

Pleurothallis lepanthopsis Schltr.

Pleurothallis lloensis Schltr.

Pleurothallis lojae Schltr.

Pleurothallis longerepens Schltr.

Pleurothallis macropus Schltr. (Fig. 39)

Pleurothallis microcharis Schltr.

Pleurothallis millei Schltr.

Pleurothallis myoxanthus Schltr.

Pleurothallis nephroglossa Schltr.

Pleurothallis nutantiflora Schltr.

Pleurothallis opeatorhyncha Schltr.

Pleurothallis otopetalum Schltr.

Pleurothallis pastazae Schltr.

Pleurothallis pichinchae Schltr.

Pleurothallis reichenbachiana Schltr.

Pleurothallis rhizomatosa Schltr.

Pleurothallis sigsigensis Schltr.

Pleurothallis sodiroi Schltr.

Pleurothallis subreniformis Schltr.

Pleurothallis superposita Schltr.

Pleurothallis tenuispica Schltr.

Pleurothallis triura Schltr.

Pleurothallis wolfiana Schltr.

Pogonia lutea Schltr. 


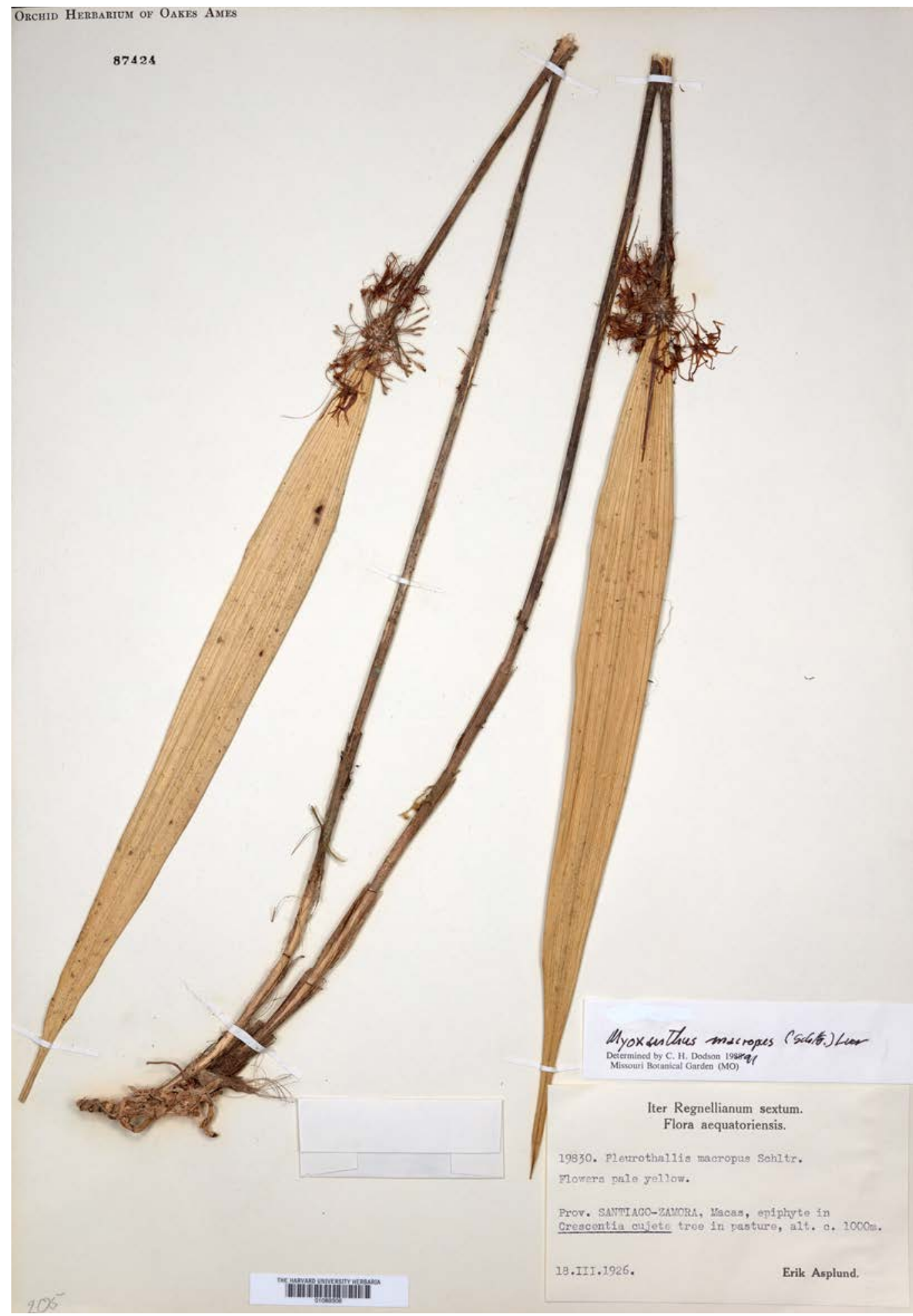

FIgURE 39. Pleurothallis macropus Schltr. Nr. 87424 - Oakes Ames Herbarium. . 


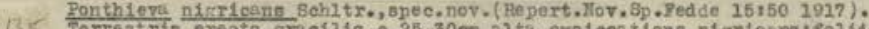

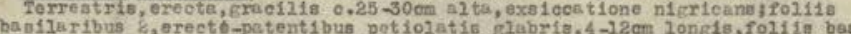

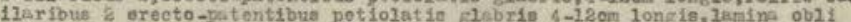

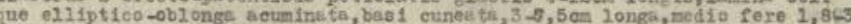

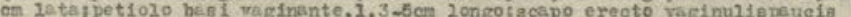

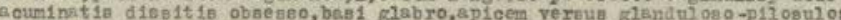

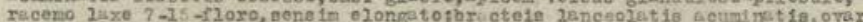
10 vulgo brevioribustiforitus in gonere vix inter nujores erecto-patent tbus inverein yeepilo intermed 10 anguate $\nabla 1 x$ frter madores erecto - pat tent ibus, in versiejaepalo inteznedio snmate oblonge obtua extue elanduiodo-puberulo, 6 an longo, anicuste oblongo, obtueo extus glandulodo-puberulo, $c .6 \mathrm{~mm}$ longo, $2 \mathrm{at}$

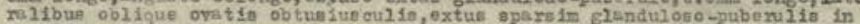
ternedio aecullongia;petelis e besi breviter unguleulata oblique aubralcat to - 2snceolat1s, obtueis lamins bas 1 margine anteriore paulo dilatats falonto

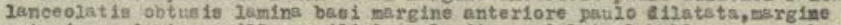
anter10re minute pap1120s0 - 11101 eta, leviter undulats 13 bello e ungue brevi

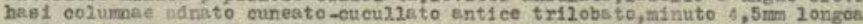

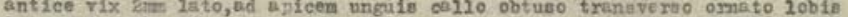

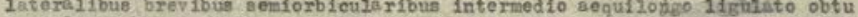
a otcoluanda brevi orassa rost 210 perbrev1 ovar10 oy 2 ind 7100 epareim glandul oso puberulo, pedicello inclueo $0.9 \mathrm{~mm}$ longo.

gotedori in collibus internindinis A.Sodiro no, 223 .

Furoh die $90 \mathrm{rm}$ der kIeinen echnion lippe ist diese Art vor alien ubrigen bisher beksunten aehr gut gekennzelohnet.

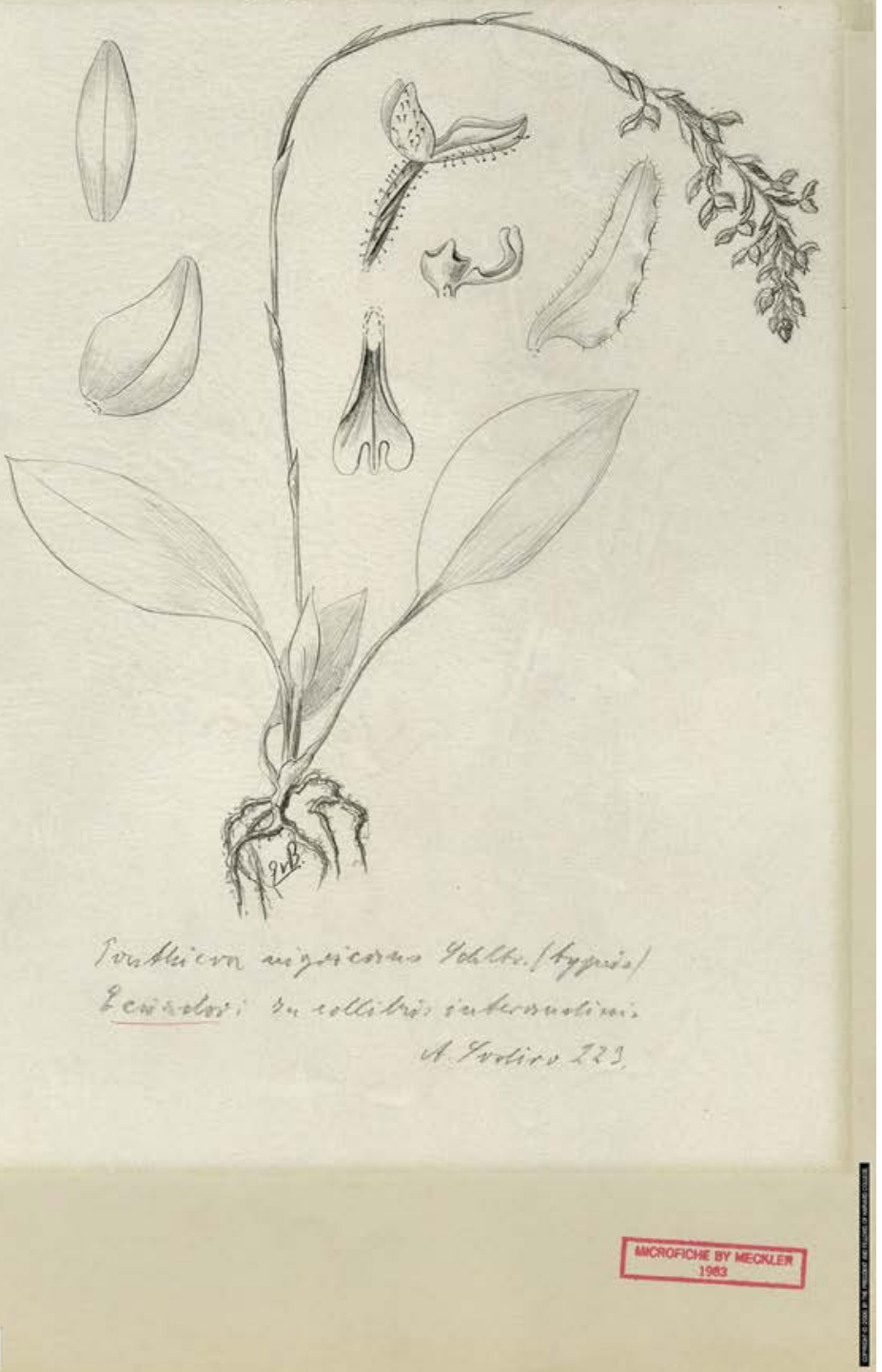

Figure 40. Drawing of the type of Ponthieva nigricans Schltr. and Schlechter's original type-written manuscript of the description of the new species. Orchid Herbarium of Oakes Ames. 


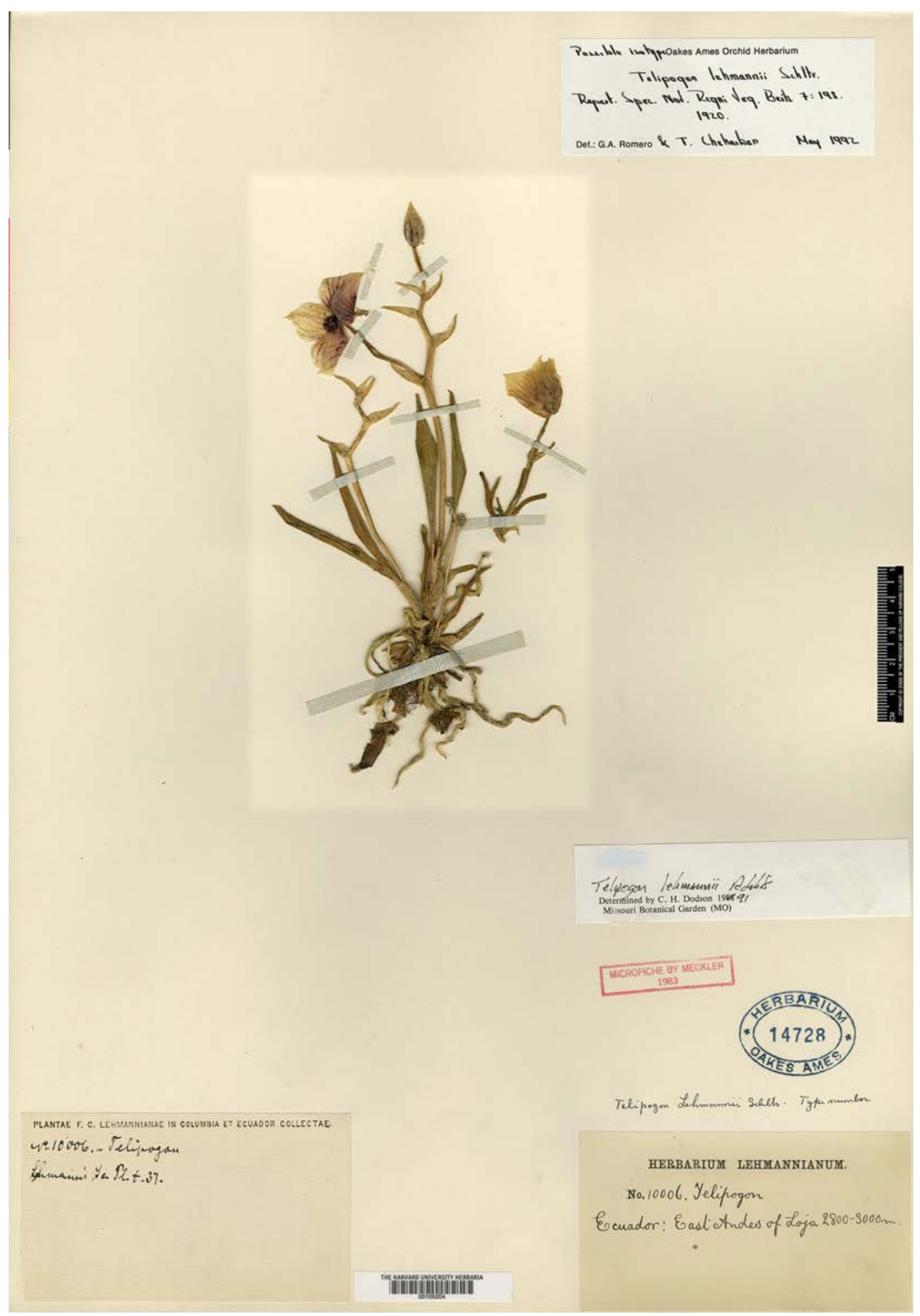

FIgURE 41. Isotype of Telipogon lehmannii Schltr. Nr. 14728 - Orchid Herbarium of Oakes Ames. 
Ponthieva appendiculata Schltr.

Ponthieva disema Schltr.

Ponthieva ecuadorensis Schltr.

Ponthieva nigricans Schltr. (Fig. 40)

Ponthieva orchioides Schltr.

Polystachya ecuadorensis Schltr.

Prescottia longipetiolata Schltr.

Pterichis pauciflora Schltr.

Pterichis seleniglossa Schltr.

Scelochilus pichinchae Schltr.

Sigmatostalix lunata Schltr.

Sobralia gracilis Schltr.

Sodiroella ecuadorensis Schltr.

Spiranthes millei Schltr.

Stelis altigena Schltr.

Stelis callicentrum Schltr.

Stelis calothece Schltr.

Stelis cordibractea Schltr.

Stelis coturcoensis Schltr.
Stelis cuencana Schltr.

Stelis hians Schltr.

Stelis lloensis Schltr.

Stelis megahybos Schltr.

Stelis millei Schltr.

Stelis perlaxa Schltr.

Stelis pilostylis Schltr.

Stelis pterostylis Schltr.

Stelis sodiroi Schltr.

Stelis superposita Schltr.

Stelis vulcanica Schltr.

Stenorrhynchos millei Schltr.

Stenorrhynchos sodiroi Schltr.

Telipogon ecuadorensis Schltr.

Telipogon lehmannii Schltr. (Fig. 41)

Telipogon pachyhybos Schltr.

Trichoceros carinifer Schltr.

Xylobium gracile Schltr.

\section{Peru (Fig. 42)}

\section{National and regional orchid floras, specific collectors}

1914 Schlechter, R. Orchidaceae. In Pilger, R. Plantae Uleanae novae vel minus cognitae. Notizblatt des Königlichen Botanischen Gartens und Museums zu Berlin, Vol. 6: 120-126.

1921 Schlechter, R. Die Orchideenfloren der südamerikanischen Kordillerenstaaten. IV. Peru. Repertorium specierum novarum regni vegetabilis, Beihefte, vol. 9: 1-182.

\section{Specific orchid tribes and subtribes, genera or species}

1911 Schlechter, R. Orchidaceae novae et criticae, Decas XVIII. Repertorium specierum novarum regni vegetabilis, Vol. 9: 161-166.

1911-1912 Schlechter, R. Orchidaceae novae et criticae, Decas XIX-XX. Repertorium specierum novarum regni vegetabilis, Vol. 10: 385-397.

1912 Schlechter, R. 1912. Neue un seltene Garten-Orchideen V. Orchis, Mitteilungen des Orchideenausschusses der Deutschen Gartenbau-Gesellschaft, vol. 6: 112-119.

1914 Schlechter, R. Neue und seltene Gardenorchideen VI. Orchis, Mitteilungen des Orchideenausschusses der Deutschen Gartenbau-Gesellschaft, vol. 8: 131-137.

1915 Schlechter, R. Neue und seltene Garten-Orchideen, VIII. Orchis, Monatsschrift der Deutschen Gesellschaft für Orchideenkunde, Vol. 9: 49-54.

Schlechter, R. Kleine Mitteilungen. Orchis, Monatsschrift der Deutschen Gesellschaft für Orchideenkunde, Vol. 9: $56-60$.

1916 Schlechter, R. Neue und seltene Garten-Orchideen, X. Orchis, Monatsschrift der Deutschen Gesellschaft für Orchideenkunde, Vol. 10: 183-190.

1918 Schlechter, R. Die Gattung Aganisia Ldl. und ihre Verwandten. Orchis, Monatsschrift der Deutschen Gesellschaft für Orchideenkunde, Vol. 12: 24-42.

1919 Schlechter, R. Die Gattung Cochlioda Ldl.. Orchis, Monatsschrift der Deutschen Gesellschaft für Orchideenkunde, Vol. 13: 3-10. 


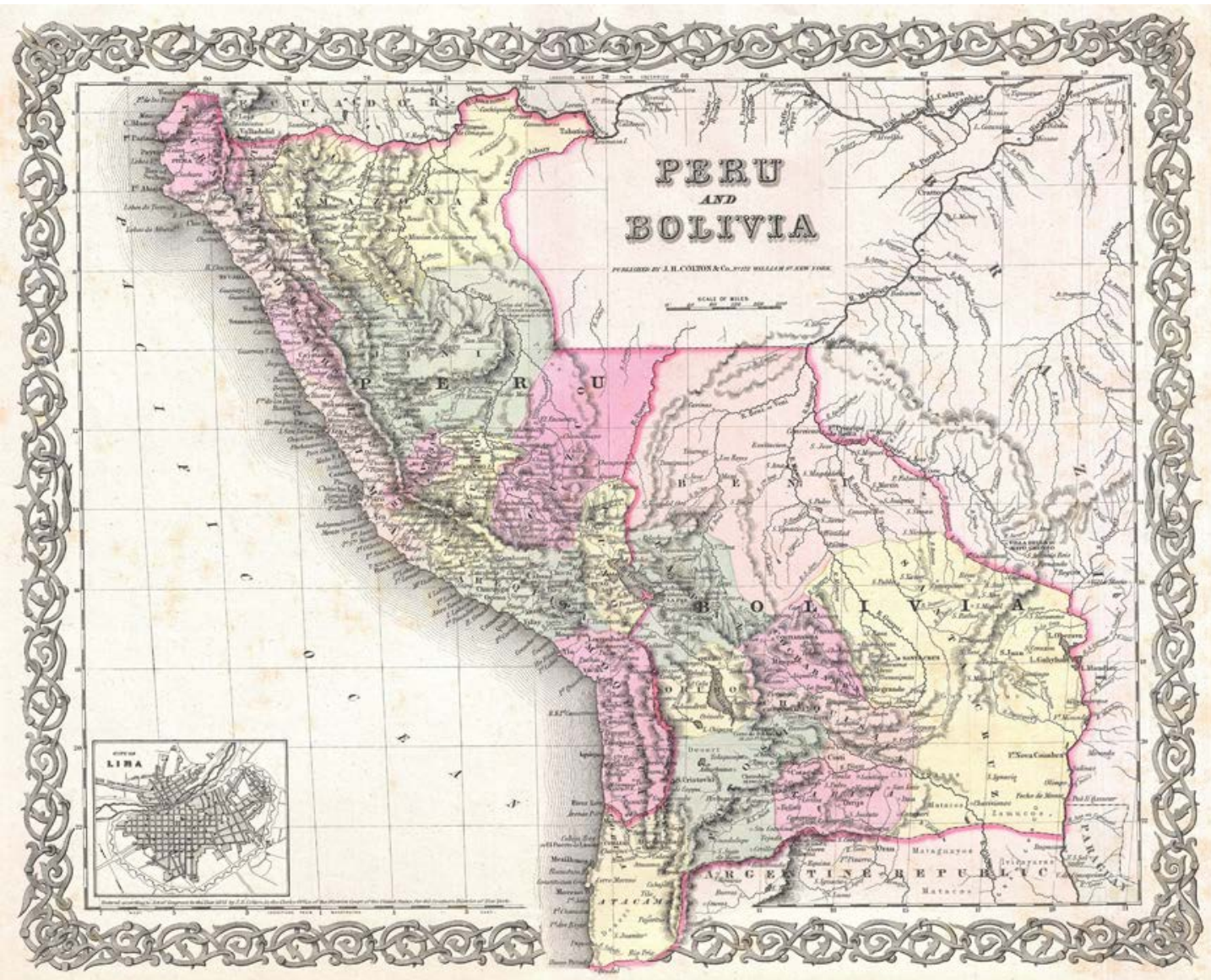

Figure 42. Map of Peru and Bolivia, 1855. Colton's Atlas of the World Illustrating Physical and Political Geography, Vol 1, New York.

1920 Schlechter, R. Versuch einer systematischen Neuordnung der Spiranthinae. Beihefte zum Botanischen Centralblatt. Zweite Abteilung, Systematik, Pflanzengeographie, angewandte Botanik 37(2): 317“454.

Schlechter's network in Peru (orchid collectors, growers and other purveyors)

- Beyrodt, Otto (1879-1923), orchid grower in Marienfelde, Germany, around 1900-1923.

- Forget, Louis (?-1915), orchid collector for Sander \& Sons.Köhler, O. Eugene (?), collected ca. 1900-1906.

- John, Karl Wilhelm (?). Orchid grower in Andernach-on-the Rhine, Germany, around 1910.

- KöHLER, Egon (father) (1866-?), Anton and Carl (sons), collected 1910-1919.

- Moore, Frederic William (1857-1949), curator of the Botanic Gardens, Glasnevin, Ireland.

- Serafín, Filomeno (1846-1922), collected ca. 1900-1910.

- Ule, Ernst Heinrich Georg (1854-1915), collected 1893-1912.

- Weberbauer, August (1871-1948), collected 1908-1948

- Wolter, Paul (1862-1942), orchid grower in Magdeburg-Wilhelmsburg. 
Orchids described by R. Schlechter from Peru (sometimes ex Kraenzl.)

The following is a list of the orchids described by R. Schlechter as new to science from Peru, as enumerated in the aforementioned bibliography (only basionyms):

Coccineorchis Schltr.

Neokoehleria Schltr.

Aa brevis Schltr.

Aa lechleri Schltr.

Aa pumilio Schltr.

Aa weberbaueri Schltr.

Amblostoma holochilon Schltr.

Batemania wolteriana Schltr.

Brachionidium serratum Schltr.

Brachystele lechleri Schltr.

Brassia filomenoi Schltr.

Brassia koehlerorum Schltr.

Campylocentrum loretoense Schltr.

Catasetum cruciatum Schltr.

Cochlioda beyrodtiana Schltr

Comparettia peruviana Schltr.

Coryanthes bicalcarata Schltr.

Cranichis koehleri Schltr.

Cryptarrhena acrensis Schltr.

Cryptocentrum minus Schltr.

Cyclopogon densiflorus Schltr.

Cyclopogon moyobambae Schltr.

Dipteranthus peruvianus Schltr.

Elleanthus bambusaceus Schltr.

Elleanthus cajamarcae Schltr.

Elleanthus caroli Schltr.

Elleanthus conchochhilus Schltr.

Elleanthus gastroglottis Schltr.

Elleanthus igneus Schltr.

Elleanthus koehleri Schltr.

Elleanthus laxifoliatus Schltr.

Elleanthus pallidiflavus Schltr.

Elleanthus porphyrocephalus Schltr.

Epidendrum bambusaceum Schltr.

Epidendrum brevicaule Schltr.

Epidendrum cajamarcae Schltr.

Epidendrum cuzcoense Schltr.

Epidendrum filomenoi Schltr.

Epidendrum fruticulus Schltr.

Epidendrum fuscum Schltr.

Epidendrum gnomus Schltr.

\section{New orchid genera}

Petalocentrum Schltr.

Symphyglossum Schltr.

\section{New orchid species}

Epidendrum haematanthum Schltr.

Epidendrum huanucoense Schltr.

Epidendrum juninense Schltr.

Epidendrum macrodonax Schltr.

Epidendrum melinoacron Schltr.

Epidendrum nephroglossum Schltr.

Epidendrum oliganthum Schltr.

Epidendrum panicoides Schltr.

Epidendrum patulipetalum Schltr.

Epidendrum platyoon Schltr.

Epidendrum pleurobothrys Schltr.

Epidendrum splendens Schltr.

Epidendrum stenophyton Schltr.

Epidendrum tarmense Schltr.

Epidendrum unifoliatum Schltr.

Epidendrum validum Schltr.

Epidendrum vinosum Schltr.

Epistephium amabile Schltr.

Epistephium macrophyllum Schltr.

Fernandezia pulchra Schltr.

Gomphichis koehleri Schltr.

Gomphichis plantaginea Schltr.

Gongora longipes Schltr.

Gongora nigropunctata Schltr.

Isochilus peruvianus Schltr.

Koellensteinia peruviana Schltr.

Lanium peruvianum Schltr.

Lepanthes juninensis Schltr.

Lepanthes koehleri Schltr.

Lueddemannia vyvereana Schltr.

Lycaste filomenoi Schltr.

Masdevallia purpurina Schltr.

Masdevallia venusta Schltr.

Masdevallia weberbaueri Schltr.

Maxillaria abelei Schltr.

Maxillaria brachypetala Schltr.

Maxillaria calantha Schltr.

Maxillaria fuerstenbergiana Schltr.

Maxillaria koehleri Schltr. 


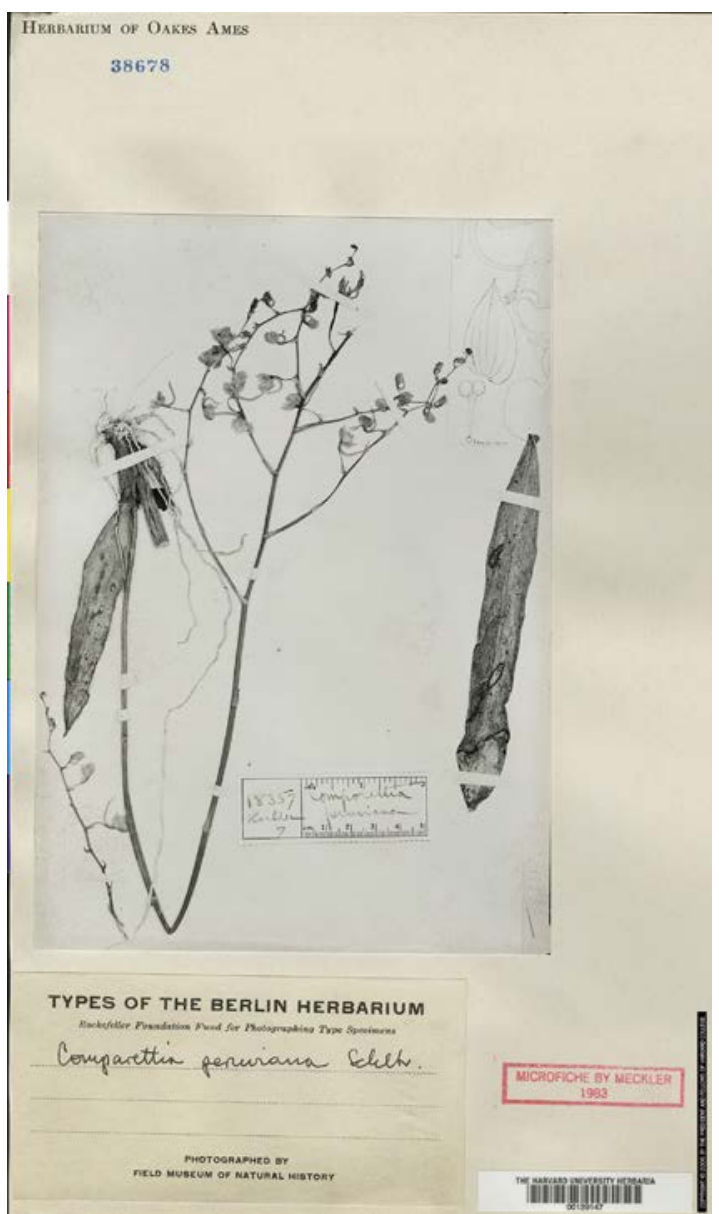

FIgURE 43. Photograph of type of Comparettia peruviana Schltr. Field Museum of Natural History, Chicago.

Maxillaria macropoda Schltr.

Maxillaria playloba Schltr.

Maxillaria weberbaueri Schltr.

Maxillaria xanthorhoda Schltr.

Neokoehleria equitans Schltr.

Neokoehleria peruviana Schltr.

Notylia coffeicola Schltr.

Notylia koehleri Schltr.

Notylia moyobambae Schltr.

Octomeria beyrodtiana Schltr. ex Mansf.

Odonglossum bellum Schltr.

Odonglossum juninense Schltr.

Odonglossum koehleri Schltr.

Odonglossum loesereniaum Schltr.

Odonglossum trilobum Schltr.

Odonglossum weberbauerianum Schltr.

Oncidium cajamarcae Schltr.

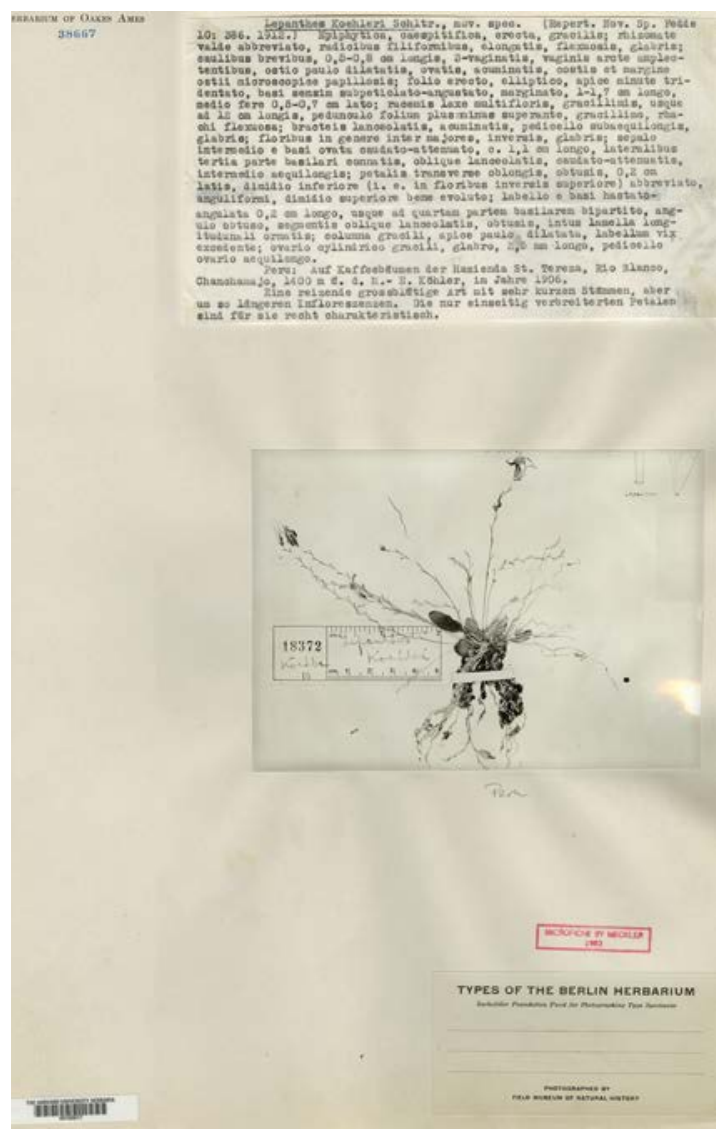

FIgURE 44. Photograph of the type of Lepanthes koehleri Schltr. and Schlechter's original type-written manuscript of the description of the new species. Nr. 38667 - Orchid Herbarium of Oakes Ames.

Ornithidium dolichophyllum Schltr.

Ornithocephalus longilabris Schltr.

Pachyphyllum breviconnatum Schltr.

Pachyphyllum lycopodioides Schltr.

Pachyphyllum tenue Schltr.

Petalocentrum angustifolium Schltr.

Petalocentrum pusillum Schltr.

Phragmipedium cajamarcae Schltr.

Physurus hetaerioides Schltr.

Physurus stenocentrum Schltr.

Pleurothallis angustilabia Schltr.

Pleurothallis brachyblephara Schltr.

Pleurothallis cajamarcae Schltr.

Pleurothallis chanchamayoensis Schltr.

Pleurothallis divaricans Schltr.

Pleurothallis genychila Schltr.

Pleurothallis graminea Schltr. 
Pleurothallis huanucoensis Schltr.

Pleurothallis juninensis Schltr.

Pleurothallis phyllostachys Schltr.

Pleurothallis tricaudata Schltr.

Pleurothallis trimeroglossa Schltr.

Polystachya altilamellata Schltr.

Polystachya poeppigii Schltr.

Ponthieva microglossa Schltr.

Ponthieva oligoneura Schltr.

Ponthieva venusta Schltr.

Ponthieva weberbaueri Schltr.

Pterichis leucoptera Schltr.

Pterichis macroptera Schltr.

Scaphyglottis antonii Schltr.

Scaphyglottis loretoensis Schltr.

Scelochilus brevis Schltr.

Schomburgkia moyobambae Schltr.

Sigmatostalix pusilla Schltr.

Sobralia alstroemerioides Schltr.

Solenidium peruvianum Schltr.
Stelis bicallosa Schltr.

Stelis filomenoi Schltr.

Stelis inversa Schltr.

Stelis koehleri Schltr.

Stelis macra Schltr.

Stelis megistantha Schltr.

Stelis melicoides Schltr.

Stelis nephropetala Schltr.

Stelis phaeantha Schltr.

Stelis piestopus Schltr.

Stelis recurvula Schltr.

Stelis rhizomatosa Schltr.

Stelis rhomboglossa Schltr.

Stelis weberbaueri Schltr.

Stenoptera elata Schltr.

Telipogon gnomus Schltr.

Trigonidium loretoense Schltr.

Trigonidium peruvianum Schltr.

Warrea speciosa Schltr.

Xylobium filomenoi Schltr.

Bolivia (Fig. 42)

\section{National and regional orchid floras, specific collectors}

1916 Schlechter, R. Herzog’s bolivianische Pflanzen III. Orchidaceae. Mededeelingen van`s Rijks Herbarium Leiden, No.29, 1916: 57-80.

1922 Schlechter, R. Die Orchideenfloren der südamerikanischen Kordillerenstaaten. V. Bolivia. Repertorium specierum novarum regni vegetabilis, Beihefte, vol. 9: 1-80.

1929 R. Schlechter. II. Orchidaceae Buchtienianae (weitere Beiträge zur Orchideenkunde von Bolivien). Repertorium specierum novarum regni vegetabilis, Vol. 27: 27-85.

\section{Specific orchid tribes and subtribes, genera or species}

1911 Schlechter, R. Orchidaceae novae et criticae, Decas XXIV. Repertorium specierum novarum regni vegetabilis, Vol.10: 428-439.

1912-1913 Schlechter, R. Orchidaceae novae et criticae, Decas XXI-XXII. Repertorium specierum novarum regni vegetabilis, Vol. 10: 445-491.

Schlechter, R. Orchidaceae novae et criticae, Decas $X X X V$. Repertorium specierum novarum regni vegetabilis, Vol.11: 41-47.

1913 Schlechter, R. Orchidaceae novae et criticae, Decas XXXIX-XLII. Repertorium specierum novarum regni vegetabilis, Vol.11: 481-494.

1915 Schlechter, R. Catasetum wredeanum n. sp.. Orchis, Monatsschrift der Deutschen Gesellschaft für Orchideenkunde, Vol. 15: 17-20.

1920 Schlechter, R. Versuch einer systematischen Neuordnung der Spiranthinae. Beihefte zum Botanischen Centralblatt. Zweite Abteilung, Systematik, Pflanzengeographie, angewandte Botanik 37(2): 317-454.

Schlechter's network in Bolivia (orchid collectors, growers and other purveyors)

- Buchtien, Otto (1859-1946), collected ca. 1893-1036.

- Fiebrig, Karl August Gustav (1879-1951)., collected 1902-1950.

LANKESTERIANA 19(2). 2019. (C) Universidad de Costa Rica, 2019. 
- GüNTHER, Ernst Karl Franz (1870-?), collected 1920s.

- Herzog, Theodor Carl Julius (1880-1961), collected 1907-1912.

- Pflanz, Carl (1872-1925), collected 1907-1925.

- SteinBach, José (1875-1930), collected 1904-1929.

- Williams, Robert Statham (1859-1945), collected 1901-1902.

\section{Orchids described by R. Schlechter from Bolivia}

The following is a list of the orchids described by R. Schlechter as new to science from Bolivia, as enumerated in the aforementioned bibliography (only basionyms):

\section{Beloglottis Schltr. \\ Buchtienia Schltr.}

Aa chiogena Schltr.

Aa microtidis Schltr.

Aa sphaeroglossa Schltr.

Aa trilobulata Schltr.

Altensteinia fiebrigii Schltr.

Beloglottis boliviensis Schltr.

Bletia mandonii Schltr.

Brassavola multiflora Schltr.

Brassia boliviensis Schltr.

Buchtienia boliviensis Schltr.

Bulbophyllum bolivianum Schltr.

Camaridium flavum Schltr.

Camaridium vagans Schltr.

Campylocentrum apiculatum Schltr.

Catasetum gardneri Schltr.

Catasetum pflanzii Schltr.

Catasetum wredeanum Schltr.

Comparettia splendens Schltr.

Cranichis mandonii Schltr.

Cyclopogon casanaensis Schltr.

Cyrtopodium buchtienii Schltr.

Cyrtopodium pflanzii Schltr.

Dichaea anguina Schltr. (Fig. 45)

Dichaea buchtienii Schltr.

Dichaea longa Schltr.

Dichaea robusta Schltr.

Dichaea stenophylla Schltr.

Elleanthus pallidiflorus

Elleanthus scopula Schltr.

Elleanthus setosus Schltr.

Encyclia buchtienii Schltr.

Encyclia pflanzii Schltr.

Encyclia steinbachii Schltr.

\section{New orchid genera}

Solenocentrum Schltr.

\section{New orchid species}

Epidendrum albiflorum Schltr.

Epidendrum alopecurum Schltr.

Epidendrum bolivianum Schltr.

Epidendrum buchtienii Schltr.

Epidendrum coroicoense Schltr.

Epidendrum cuneatum Schltr.

Epidendrum herzogii Schltr.

Epidendrum humidicolum Schltr.

Epidendrum lanioides Schltr.

Epidendrum miguelii Schltr.

Epidendrum nigricans Schltr.

Epidendrum obliquum Schltr.

Epidendrum physophorum Schltr.

Epidendrum quinquepartitum Schltr.

Epidendrum syringodes Schltr.

Epidendrum theodori Schltr.

Epidendrum trichopetalum Schltr.

Galeandra fiebrigii Schltr.

Habenaria bangii Schltr.

Habenaria bermejoensis Schltr.

Habenaria buchtienii Schltr.

Habenaria herzogii Schltr.

Habenaria leptantha Schltr.

Habenaria miguelii Schltr.

Habenaria ottonis Schltr.

Habenaria petrogeiton Schltr.

Habenaria pseudorepens Schltr.

Habenaria subandina Schltr.

Habenaria theodori Schltr.

Habenaria williamsii Schltr.

Habenaria yungasensis Schltr.

Houlletia boliviana Schltr.

Kefersteinia pulchella Schltr. 


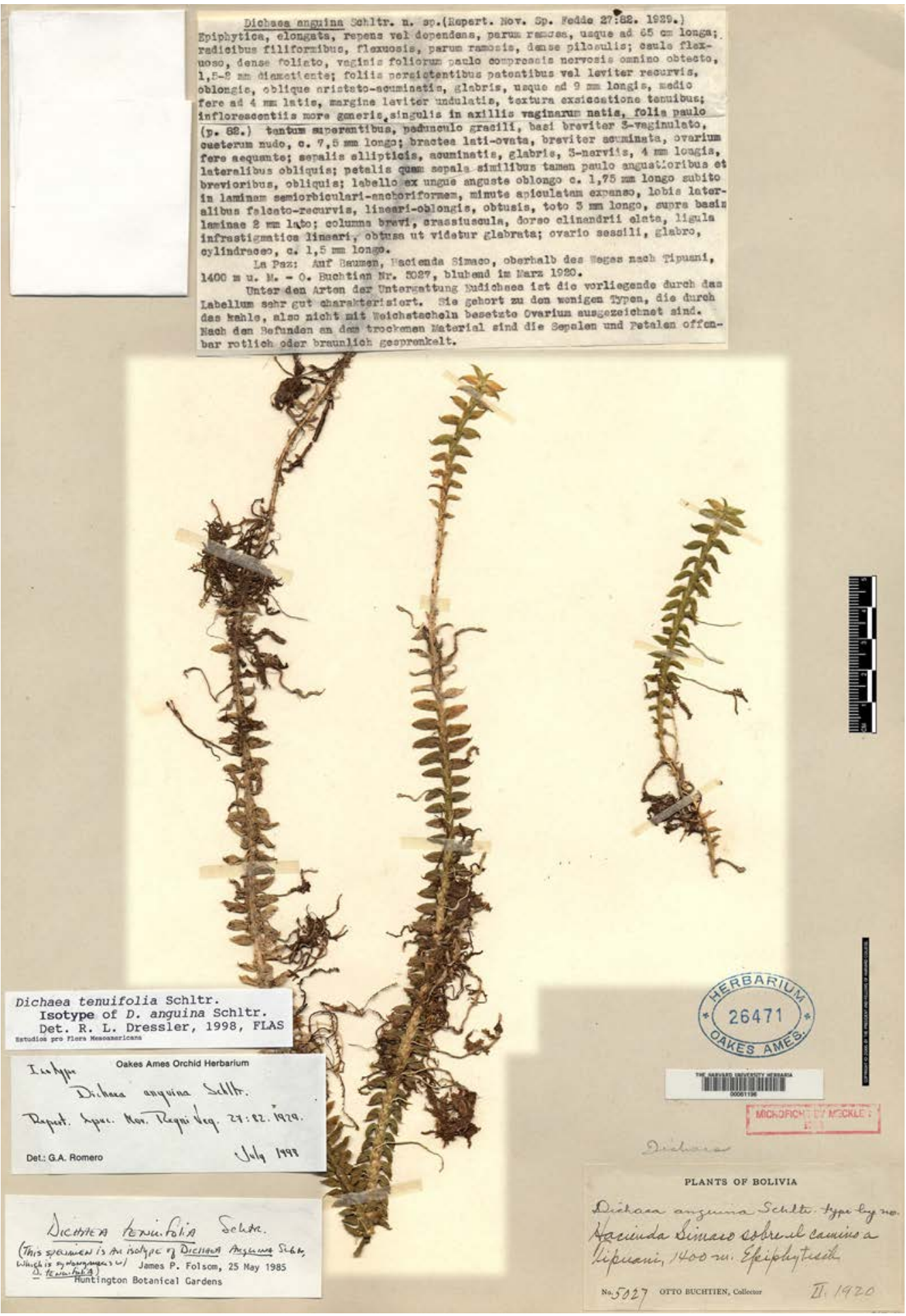

FIGURE 45. Isoype of Dichaea anguina Schltr. and Schlechter's original type-written manuscript of the description of the new species. Nr. 26471 - Orchid Herbarium of Oakes Ames. 
Lepanthes rupicola Schltr. Lepanthes sillarensis Schltr. Liparis otophyllon Schltr. Lycaste neglecta Schltr. Macradenia buchtienii Schltr. Masdevallia bangii Schltr. Masdevallia boliviensis Schltr. Masdevallia brachyantha Schltr. Masdevallia bradei Schltr. ex Hoehne Masdevallia buchtienii Schltr. (Fig. 46) Masdevallia herzogii Schltr. Masdevallia setipes Schltr. Masdevallia tubata Schltr. Masdevallia xanthura Schltr. Maxillaria boliviensis Schltr. Maxillaria buchtienii Schltr. Maxillaria compressibulba Schltr. Maxillaria dolichophylla Schltr. Maxillaria fallax Schltr. Maxillaria gracilipes Schltr. Maxillaria leucantha Schltr. Maxillaria ongicaulis Schltr. Maxillaria oxysepala Schltr. Maxillaria poifolia Schltr. Maxillaria simacoana Schltr. Maxillaria xylobiiflora Schltr. Microstylis boliviana Schltr. Microstylis buchtienii Schltr. Microstylis mixta Schltr. Microstylis nasuta Schltr. Microstylis ottonis Schltr. Microstylis reichenbachiana Schltr. Microstylis tridentula Schltr. Neodryas herzogii Schltr. Notylia boliviensis Schltr. Notylia buchtienii Schltr. Octomeria buchtienii Schltr.

Octomeria tenuis Schltr.

Odonglossum rigidum Schltr. Oncidium bolivianum Schltr. Oncidium buchtienii Schltr. Oncidium herzogii Schltr. Oncidium williamsii Schltr. Ornithidium bolivianum Schltr. Ornithidium rhomboglossum Schltr. Pachyphyllum falcifolium Schltr. Pachyphyllum herzogii Schltr. Pachyphyllum minus Schltr.
Pelexia fiebrigii Schltr.

Physosiphon andinum Schltr.

Physosiphon herzogii Schltr.

Physurus anchoriferus Schltr.

Physurus buchtienii Schltr.

Physurus herzogii Schltr.

Pleurothallis amblyopetala Schltr.

Pleurothallis boliviana Schltr.

Pleurothallis buchtienii Schltr.

Pleurothallis bulbophylloides Schltr.

Pleurothallis coffeicola Schltr.

Pleurothallis dolichocaulon Schltr.

Pleurothallis frutex Schltr.

Pleurothallis guentheri Schltr.

Pleurothallis herpethophyton Schltr.

Pleurothallis herzogii Schltr.

Pleurothallis ottonis Schltr.

Pleurothallis papuligera Schltr.

Pleurothallis rhopalocarpa Schltr.

Pleurothallis sanjanae Schltr.

Pleurothallis scleropus Schltr.

Pleurothallis simacoana Schltr.

Pleurothallis spathata Schltr.

Pleurothallis tenuiflora Schltr.

Pleurothallis triptera Schltr.

Pleurothallis tripterocarpa Schltr.

Pleurothallis triquetra Schltr.

Pleurothallis umbraticola Schltr.

Pleurothallis yungasensis Schltr.

Polystachya boliviensis Schltr.

Polystachya simacoana Schltr.

Ponthieva elegans Schltr.

Pterichis boliviana Schltr.

Pterichis saxicola Schltr.

Pterichis silvestris Schltr.

Pterichis yungasensis Schltr.

Sarcoglottis herzogii Schltr.

Scaphyglottis boliviana Schltr.

Sobralia boliviensis Schltr.

Sobralia buchtienii Schltr.

Sobralia caloglossa Schltr.

Sobralia fructicetorum Schltr.

Sobralia herzogii Schltr.

Spiranthes goodyeroides Schltr.

Stelis atrobrunnea Schltr.

Stelis buchtienii Schltr.

Stelis casanaensis Schltr.

Stelis lexa Schltr. 


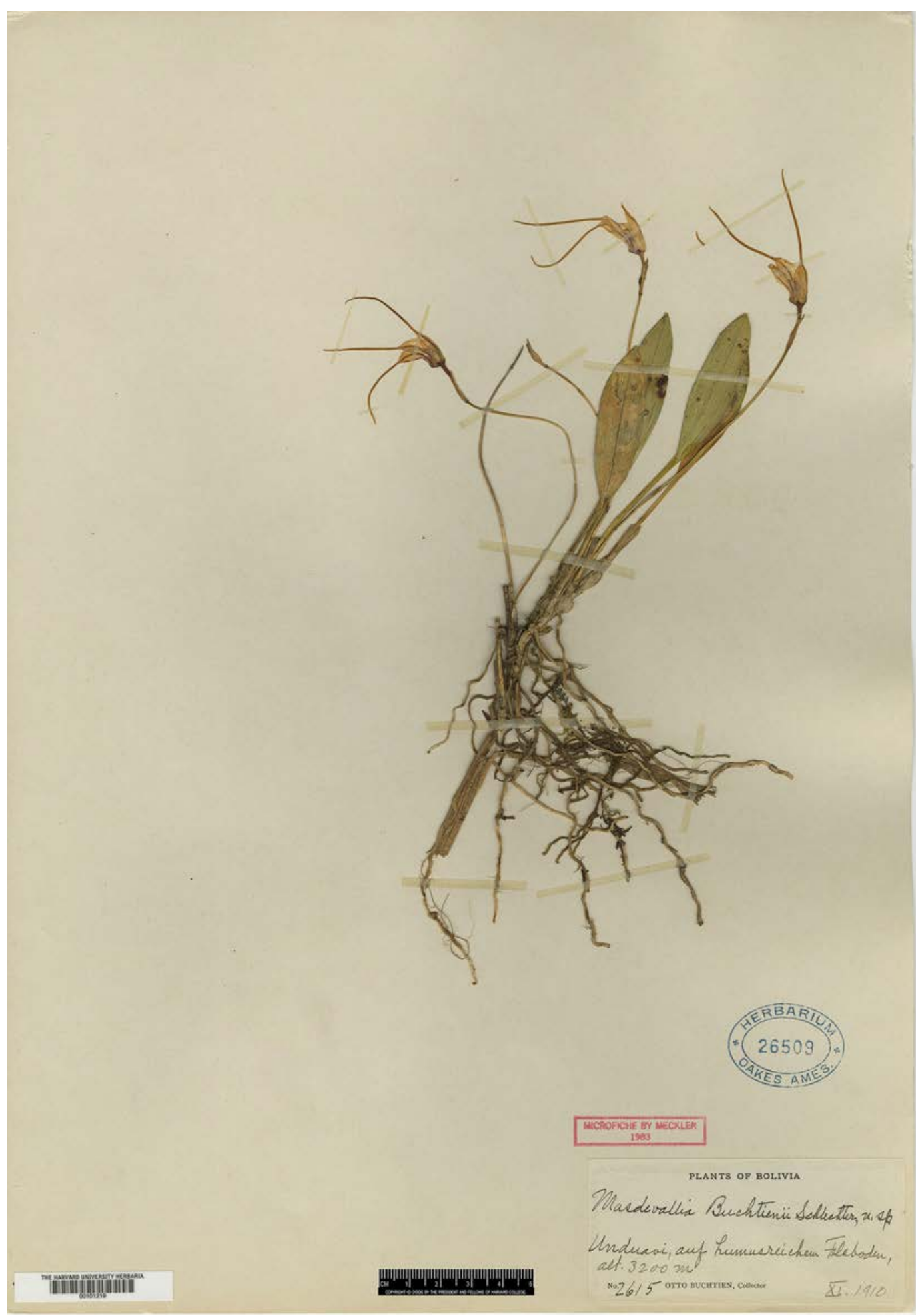

FIGURE 46. Isotype of Masdevallia buchtienii Schltr. Nr. 26509 - Orchid Herbarium of Oakes Ames. 
Stelis herzogii Schltr.

Stelis heterosepala Schltr.

Stelis laxa Schltr.

Stelis mandoniana Schltr.

Stelis microtathanta Schltr.

Stelis naviculigera Schltr.

Stelis ottonis Schltr.

Stelis phaeomelana Schltr.

Stelis polycarpa Schltr.

Stelis saxicola Schltr.

Stelis simacoensis Schltr.
Stelis trianguliflora Schltr.

Stelis vagans Schltr.

Stelis virens Schltr.

Stelis xanthantha Schltr.

Stelis yungasensis Schltr.

Stenoptera plantaginea Schltr.

Trizeuxis andina Schltr.

Xylobium flavescens Schltr.

Xylobium latifolium Schltr.

Zygopetalum bolivianum Schltr.

Chile (Fig. 47)

With the exception of a few articles on the climate of the orchid-rich countries of the sub-continent, Schlechter did not publish anything on the orchids of Chile. The reason, as he states in the prologue to his last volume on the orchid-floras of the Andean countries (V. Bolivia, 1922) was the appearance in 1910 of Karl Reiche's Orchidaceae Chilenses, ensayo de una monografia de las Orquideas de Chile ${ }^{12}$, under the assumption that not many novelties could be expected in the short period of time elapsed since its publication.

However, in his Monograph on the Spiranthinae (1920) Schlechter published a new combination: Brachystele unilateralis (Por.) Schltr.

${ }^{12}$ Reiche, K. 1910. Orchidaceae Chilenses, ensayo de una monographia de las Orquideas de Chile. Anales del Museo Nacional de Chile, vol. 18.

Argentina (Fig. 47)

\section{Specific orchid tribes and subtribes, genera or species}

1917-1919 Schlechter, R. Orchidaceae novae et criticae, Decas LIV. Repertorium specierum novarum regni vegetabilis, Vol.15: 210-217.

Schlechter, R. Orchidaceae novae et criticae, Decas $L X V$. Repertorium specierum novarum regni vegetabilis., Vol. 16: 353-358.

1920 Schlechter, R. Versuch einer systematischen Neuordnung der Spiranthinae. Beihefte zum Botanischen Centralblatt. Zweite Abteilung, Systematik, Pflanzengeographie, angewandte Botanik 37(2): 317-454.

Schlechter's network in Argentina (orchid collectors, growers and other purveyors)

- Hieronymus, Georg Hans Emmo (1845-1921), collected 1872-1883.

- Wendt, H. (?), collected 1907-1912.

\section{Orchids described by R. Schlechter from Argentina}

The following is a list of the orchids described by R. Schlechter as new to science from Argentina, as enumerated in the aforementioned bibliography (only basionyms):

\section{New orchid genera}

Pteroglossa Schltr.

\section{New orchid species}

Aa achalensis Schltr.

Aa schickendanzii Schltr.

Aa lorentzii Schltr.

Chloraea reticulata Schltr. 


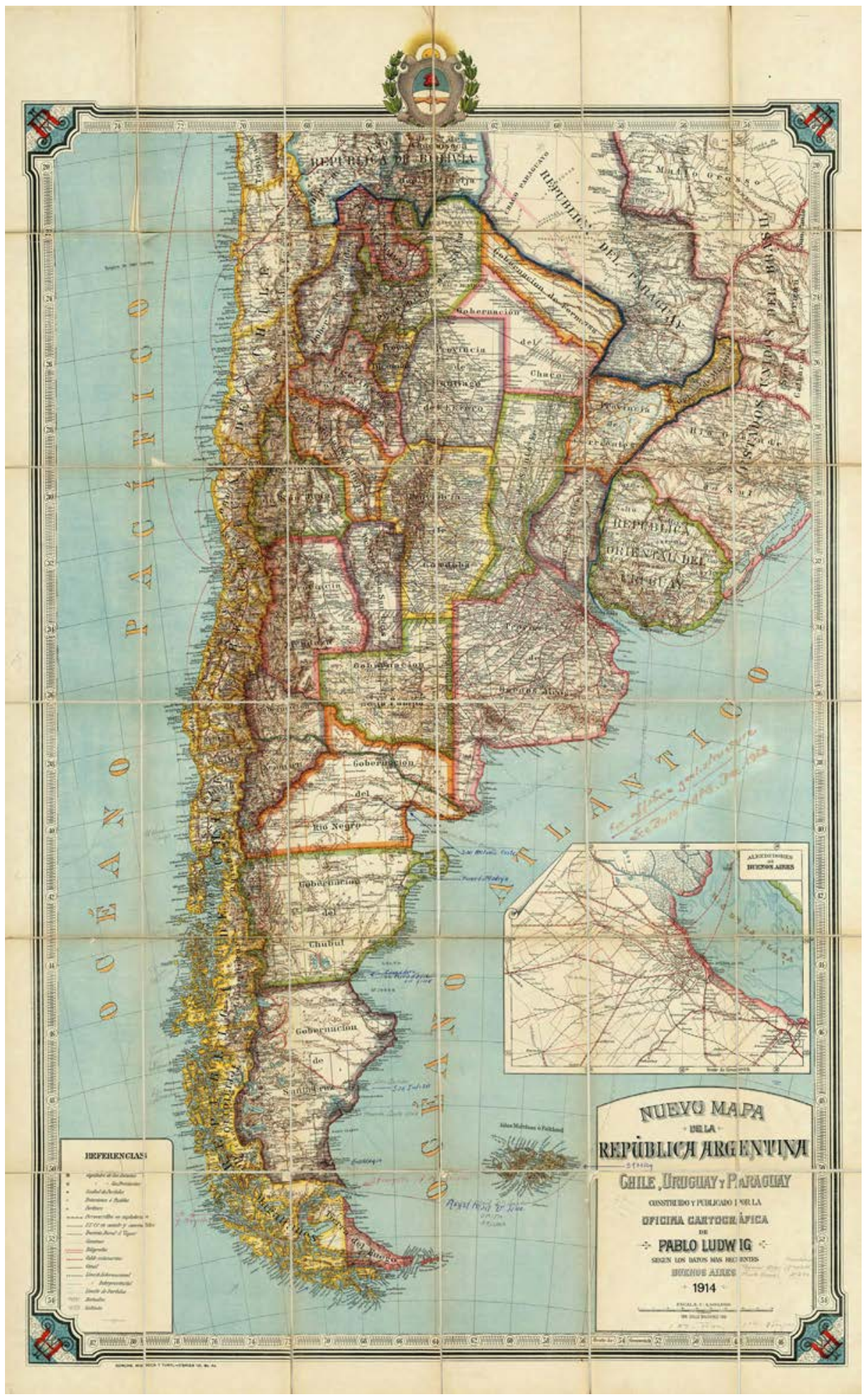

FiguRe 47. Map of Chile, Argentina, Paraguay \& Uruguay by Pablo Ludwig, 1914. 


\section{Paraguay (Fig. 47)}

\section{Specific orchid tribes and subtribes, genera or species}

1910-1911 Schlechter, R. Orchidaceae novae et criticae, Decas XVI-XVII. Repertorium specierum novarum regni vegetabilis, Vol.10: 21-32.

1917-1919 Schlechter, R. Orchidaceae novae et criticae, Decas $L X V$. Repertorium specierum novarum regni vegetabilis., Vol. 16: 353-358.

1920 Schlechter, R. Versuch einer systematischen Neuordnung der Spiranthinae. Beihefte zum Botanischen Centralblatt. Zweite Abteilung, Systematik, Pflanzengeographie, angewandte Botanik 37(2): 317-454.

1925 Schlechter. R. Orchidaceae novae et criticae, Decas LXXVIII-LXXIX. Repertorium specierum novarum regni vegetabilis, Vol. 21: 330-343.

Schlechter's network in Paraguay (orchid collectors, growers and other purveyors)

- Fiebrig, Karl August Gustav (1879-1951), collected 1902-1950.

- Hassler, Emil (1864-1937), collected 1895-1909, 1914, 1920-1937.

- Rojas Vera, Teodoro (1877-1954), collected 1907-1944.

- Wend, H. (?), collected 1907-1912.

\section{Orchids described by R. Schlechter from Paraguay}

The following is a list of the orchids described by R. Schlechter as new to science from Paraguay, as enumerated in the aforementioned bibliography (only basionyms):

\section{New orchid species}

Habenaria amambayensis Schltr.

Habenaria deistelii

Habenaria fiebrigii Schltr.

Habenaria schindleri
Oncidium emilii Schltr.

Oncidium minutiflorum Schltr.

Oncidium ostenianum Schltr. (Fig. 48)

Ponthieva hassleri Schltr.

\section{URUGUAY (Fig. 47)}

The only mention to orchids from Uruguay in Schlechter's publiactions are new combinations in the genus Brachystele, which he published in his monograph on the Spiranthinae (1920): B. arechavaletae (Kränzl.) Schltr., B. camporum (Lind1.) Schltr. and B. dilatata (Lindl.) Schltr.

\section{AdDitional Literature}

Ames, O. (1944). Destruction of the Schlechter Herbarium by Bombing. American Orchid Society Bulletin, 13(4).

Ames, O. (1979). Jottings of a Harvard botanist. Botanical Museum of Harvard University. Cambridge, Massachusetts.

Cribb, P. (2010). The life and travels of Friedrich Carl Lehmann. Lankesteriana, 10(2-3), 9-30.

Fibeck, W. (2012-2014). Rudolf Schlechter(1872-1925). Leben und Wirken einer Orchideologenlegende. Orchideenjournal,

19(1), 119-127 (Part 1); 19(4), 163-170 (Part 2); 20(2), 71-81 (Part 3); 20(4), 161-169 (Part 4); 21(2), 59-68 (Part 5).

Fibeck, W. (2015). "Es gibt noch viel zu tun." Zum 90. Todestag von Rudolf Schlechter. Orchideenjournal 22(4), 145-147.

Field Museum of Natural History (2018). Berlin negatives. Retrieved at https://www.fieldmuseum.org/node/5186.

Harvard University (2018a). Correspondence files of the Oakes Ames Orchid Herbarium. 1909-1960. Correspondence between Oakes Ames, Rudolf Schlechter and Alexandra Schlechter.

Harvard University (2018b). Correspondence files of the Oakes Ames Orchid Herbarium. 1921-1924. Correspondence between Oakes Ames and Charles W. Powell. 


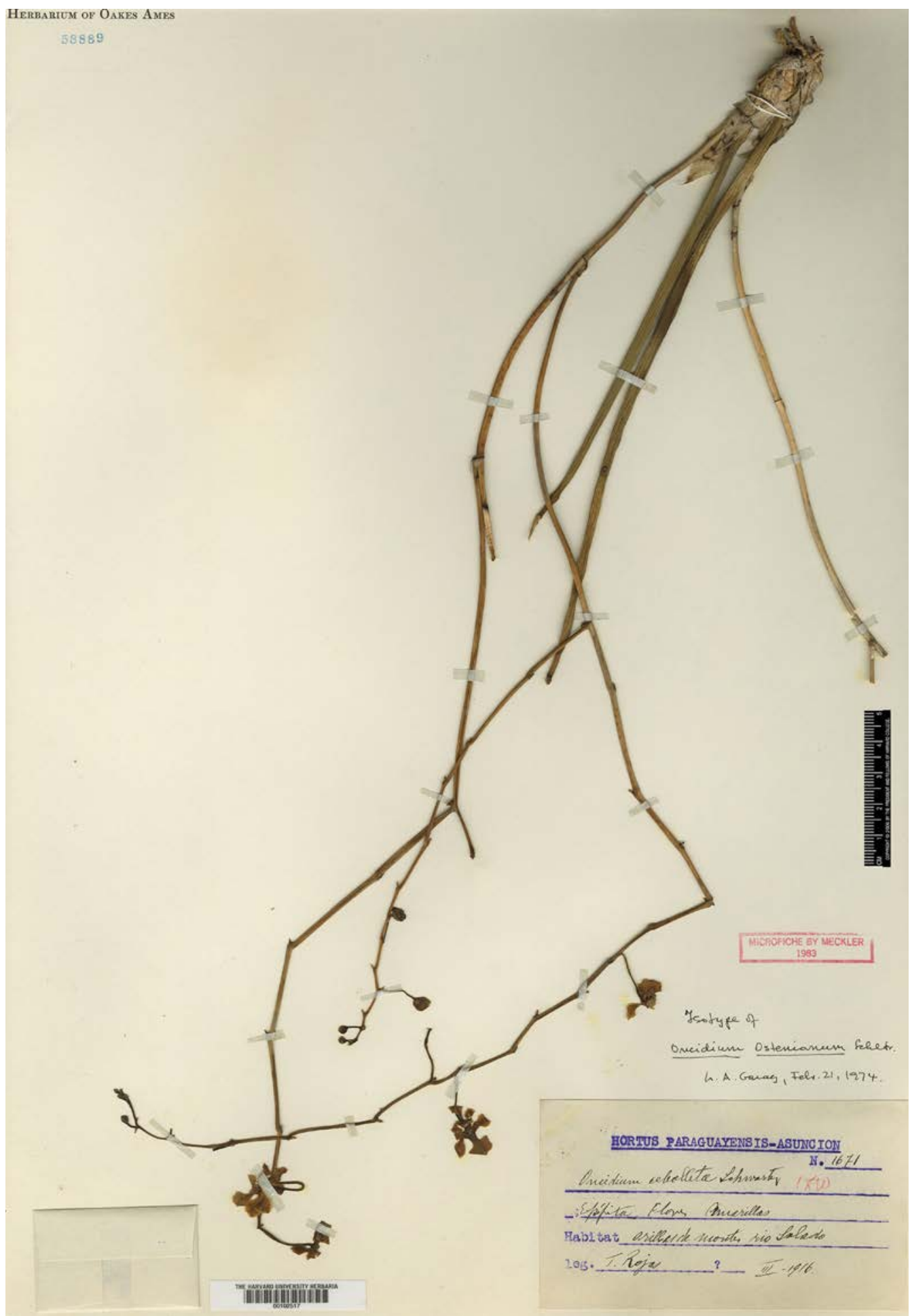

FIgURE 48. Isotype of Oncidium ostenianum Schltr.collected by T. Rojas in Paraguay. Nr. 58889 - Orchid Herbarium of Oakes Ames. 
Harvard University (2018c). Correspondence files of the Oakes Ames Orchid Herbarium. 1922-1962. Correspondence between Oakes Ames and Charles H. Lankester.

Kew Botanic Gardens (2019). International Plant Names Index. Retrieved at https://www.ipni.org/

Loesener, T. (1926). Rudolf Schlechters Leben und Wirken. Notizblatt des Botanischen Gartens und Museums BerlinDahlem, 9(80), 912-958.

Morales, C. (2006). Cien años de la Sociedad Alemana de Orquideología (1906-2006). Lankesteriana, 6(3), 91-94.

Natural History Museum (2013). Schlechter, Friedrich Richard Rudolf (1872-1925). Retrieved at JStor.

Ossenbach, C. (2009). Orchids and orchidology in Central America: 500 years of history. Lankesteriana, 9(1-2), 1-268.

Reinikka, M. A. (1995). A History of the Orchid. Timber Press, Portland, Oregon.

Schultz, M. (2013). The Orchid Types of the Herbarium Hamburgense (HBG). Verhandlungen des Naturwissenschaftlichen Vereins in Hamburg, 47, 5-145.

Schonland, S. (1897). Report of the Committee of the Albany Museum. Grahamstown, South Africa.

Senghas, K. (2002). Leben und Wirken von Rudolf Schlechter. In Bibliographie der Orchideen-kunde und Rudolf Schlechter, Biographie / Bibliography of Orchidology and Rudolf Schlechter, Biography. Sonderabdruck aus Schlechter, Die Orchideen. 3. Auflage, Band I, Literatur- und Registerband. Berlin, Parey Buchverlag. S. v-XI, 1-146. 
